\title{
SQUATTER AGENCY:
}

Architecture as Empowerment in the Global South

\author{
by \\ Dustin Grant Unrau \\ M.Arch Candidate
}

A thesis submitted to the Faculty of Graduate and Postdoctoral Affairs in partial fulfillment of the requirements for the degree of

\section{Masters of Architecture (M.ARCH Professional)}

Carleton University

Ottawa, Ontario

(C) 2012 
Library and Archives

Canada

Published Heritage

Branch

395 Wellington Street

Ottawa ON K1A ON4

Canada
Bibliothèque et

Archives Canada

Direction du

Patrimoine de l'édition

395 , rue Wellington

Ottawa ON K1A ON4

Canada
Your file Votre référence

ISBN: 978-0-494-91530-1

Our file Notre référence

ISBN: 978-0-494-91530-1
NOTICE:

The author has granted a nonexclusive license allowing Library and Archives Canada to reproduce, publish, archive, preserve, conserve, communicate to the public by telecommunication or on the Internet, loan, distrbute and sell theses worldwide, for commercial or noncommercial purposes, in microform, paper, electronic and/or any other formats.

The author retains copyright ownership and moral rights in this thesis. Neither the thesis nor substantial extracts from it may be printed or otherwise reproduced without the author's permission.
AVIS:

L'auteur a accordé une licence non exclusive permettant à la Bibliothèque et Archives Canada de reproduire, publier, archiver, sauvegarder, conserver, transmettre au public par télécommunication ou par l'Internet, prêter, distribuer et vendre des thèses partout dans le monde, à des fins commerciales ou autres, sur support microforme, papier, électronique et/ou autres formats.

L'auteur conserve la propriété du droit d'auteur et des droits moraux qui protege cette thèse. $\mathrm{Ni}$ la thèse ni des extraits substantiels de celle-ci ne doivent être imprimés ou autrement reproduits sans son autorisation.
In compliance with the Canadian Privacy Act some supporting forms may have been removed from this thesis.

While these forms may be included in the document page count, their removal does not represent any loss of content from the thesis.
Conformément à la loi canadienne sur la protection de la vie privée, quelques formulaires secondaires ont été enlevés de cette thèse.

Bien que ces formulaires aient inclus dans la pagination, il n'y aura aucun contenu manquant. 


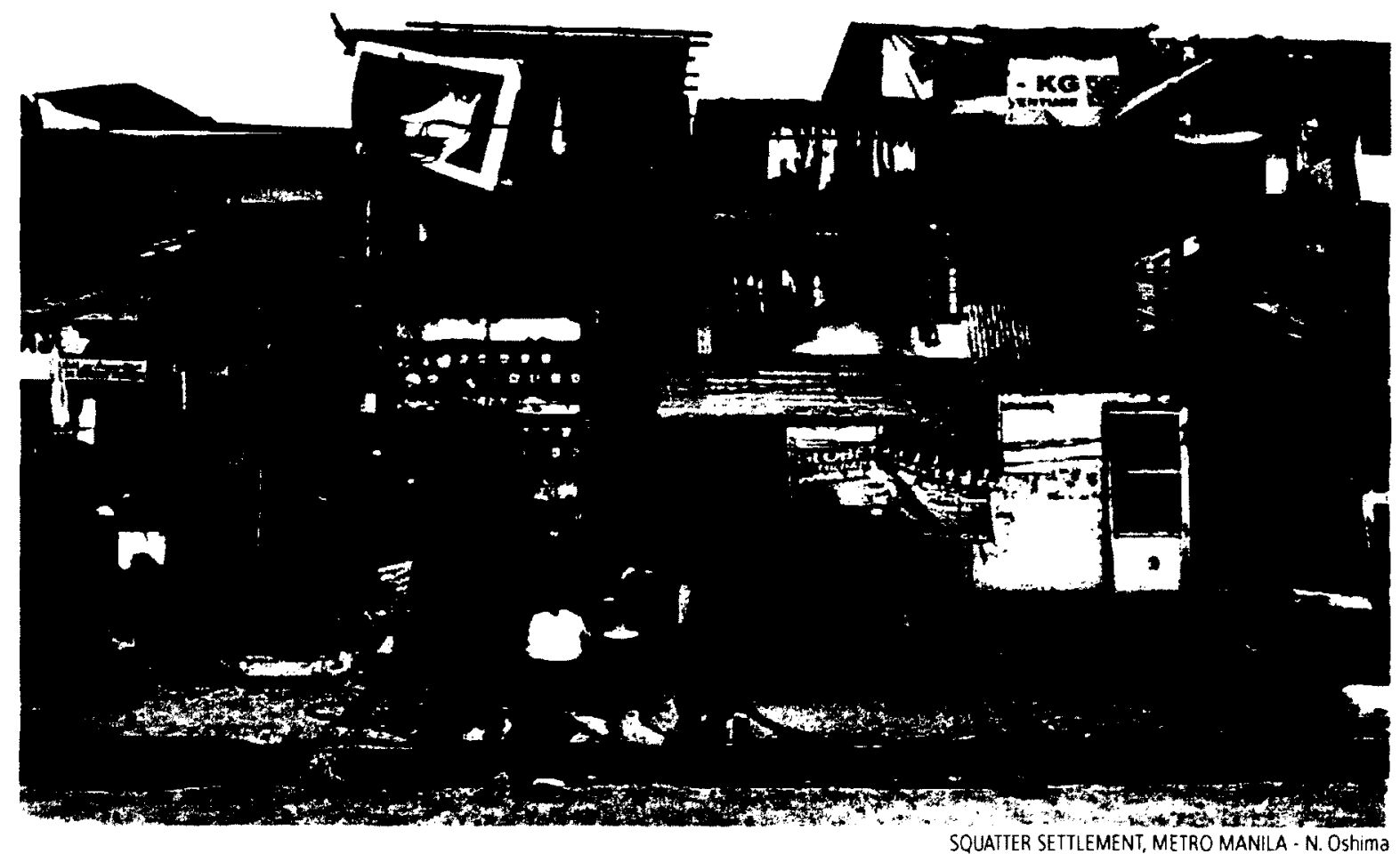




\section{ABSTRACT}

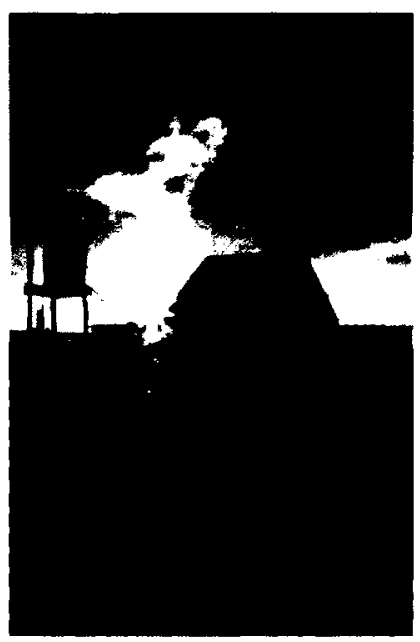

INFORMAL SHACX, CABO POLONIO. URUGUAY - Vava Ribeiro
Squatters have been perceived by some as a cancer on the world's developing cities. However, with over $1 / 3$ of the world's population expected to squat in informal urban settlements by the middle of this century, squatters might also be considered the future of the world's developing cities. Will the cancer overcome the urban body and kill it? Or will third-world cities learn to thrive on the ingenuity of the massive networks of unplanned (dis)order built by the urban poor? This thesis argues that architecture should detach itself from its current autonomous stance of merely being engaged in the practice of apolitical formalism, with little regard to a social agenda. Architecture should instead move towards a collaborative, trans-disciplinary approach, where architects operate professionally as agents who act with, and on behalf of others. By doing so, architects might better empower squatters, enabling change within their informality. 


\section{ACKNOWLEDGEMENTS}

First and foremost I offer my sincerest gratitude to my advisor, Professor Roger Connah (or Professor Vertigo?), for his serenity, commitment, and immense knowledge. His guidance and support, along with the much needed shots of espresso, were essential for the development of this thesis. I could not have imagined having a better advisor and mentor.

Special thanks to my committee Dr. Kelly Crossman, Mark Baechler and Dr. Claudio Sgarbi for their guidance and helpful suggestions. In addition, I would like to express my gratitude to Estudio Teddy Cruz, Dr. Shelagh McCartney, and Habitat International Coalition President Lorena Zárate, who offered their valuable time and insight during the development of this thesis. Their knowledge and appreciation of the issue of informal settlements is outstanding, and I greatly appreciate their generous availability and honest feedback.

To my friends, family and colleagues - thank you for being sources of laughter, rest, and support. I came to Ottawa not knowing what to expect from my masters experience, and now I leave with many new memories and friendships that will last for a lifetime. I hope you are all blessed with success and joy in the future.

Finally, this thesis is dedicated to my parents, Dennis and Diane Unrau, who have always supported me and who taught me, through their own example, the values of dedication, humility, and compassion. Your life is inspiring and I am proud to be your son. 


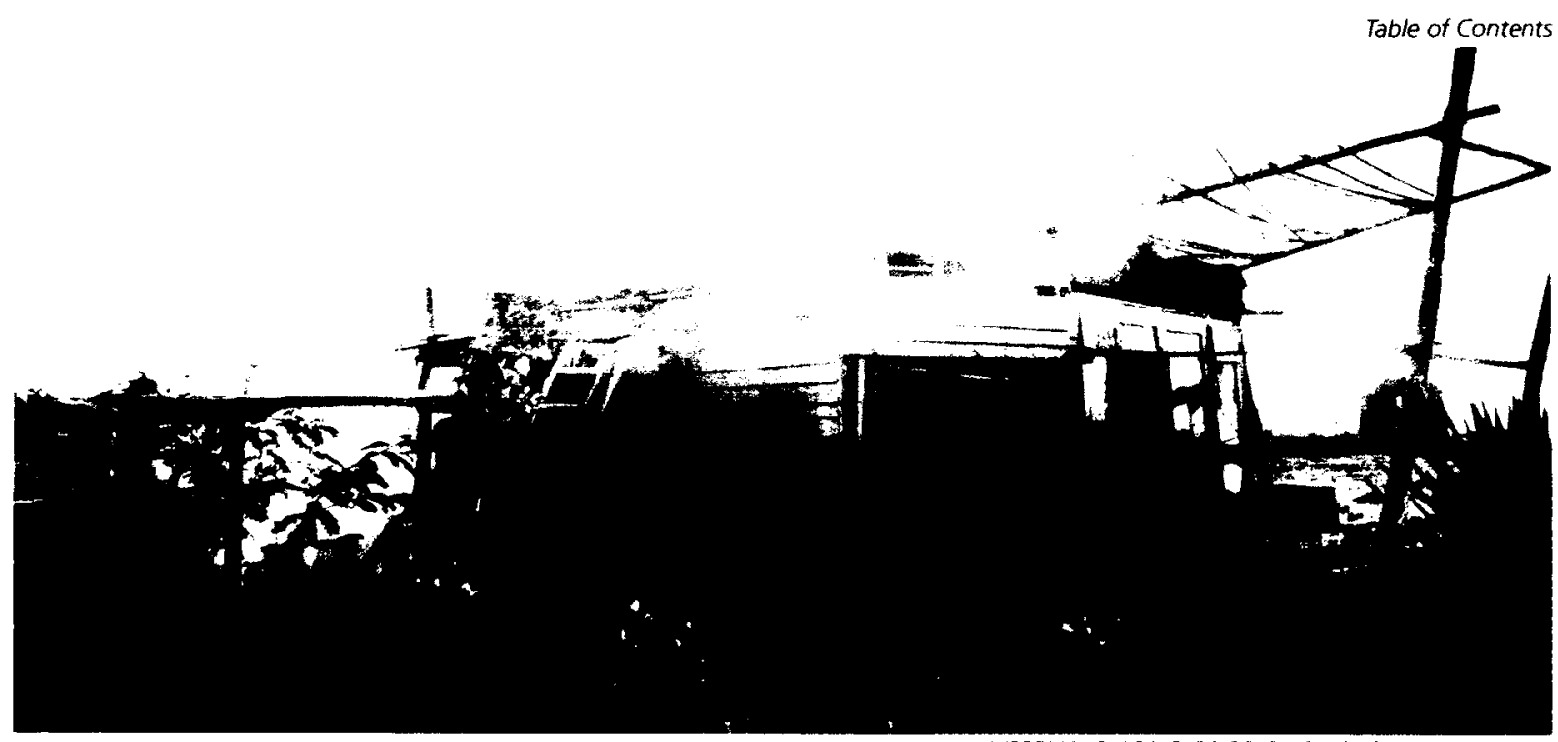

INFORMAL SHACK, CABO POLONIO, URUGUAY - Vava Ribeiro

CONTENTS

1. ABSTRACT

2. PREFACE

\section{INTRODUCTION - SQUATTERS IN CONTEXT}

In order to appropriately appreciate the situation in which squatters live, it is essential to understand the historical precedents, cultural context and global evolution of informal squatter settlements.

\section{SLUM-ACHITECTURE / HYPER-AESTHETICS}

Third-world slums have developed exponentially at a far greater pace than the rest of the built environment, yet these settlements go relatively unperceived by a seemingly autonomous architectural profession which is focused more on formal experimentation. The purpose of this chapter is to explore 'SlumArchitecture', and the merits of architecture without architects.

\section{SQUATTER AGENCY}

What should the role of the architect be when dealing with squatters and their communities? What boundaries should architecture work within in order to be of benefit to informal settlements, without overimposing their presence? How can architects work as agents, with and for squatters, to enable their empowerment?

\section{THE PARACHUTIST'S ALTERNATIVE}

An architectural project responding to the thesis and addressing the questions related to the role of the architect as an agent of change in the global south. The project will address the specific situation of the informal settlement in Chimalhuacán, Mexico and it will propose interventions that respond to the lack of infrastructure, unsanitary and dangerous living conditions and the lack of community involvement spaces within the existing urban fabric. The project will be formatted as a pamphlet that can be reproduced and distributed within the informal settlement as a way to inform squatters (or parachutists) of alternative architectural solutions for an improved community development. 


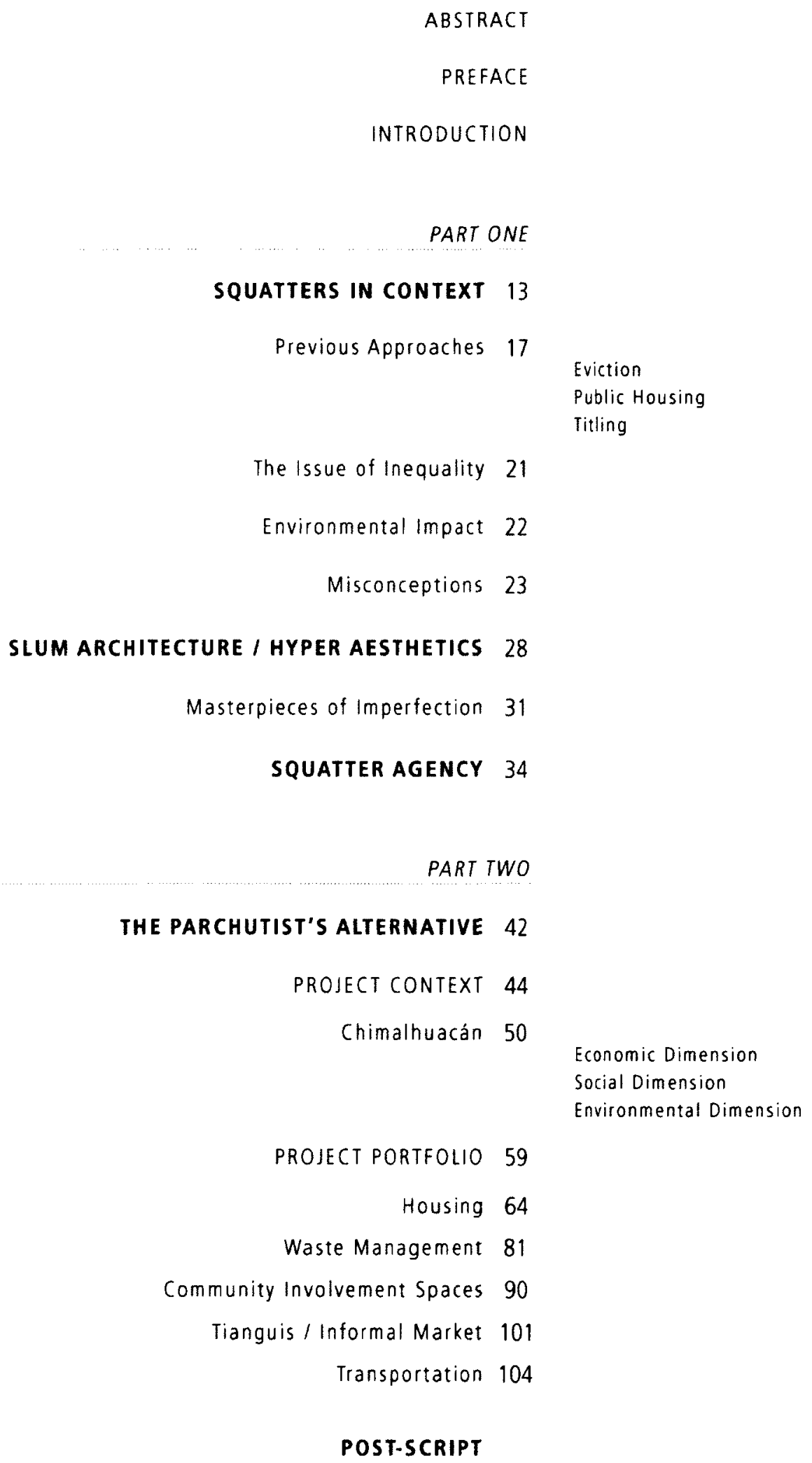


PREFACE

'You never change things by fighting the existing reality. To change something, build a new model that makes the existing model obsolete'.

-Buckminster Fuller

Growing up in Mexico constantly prompted me to reflect on the situation that affects countless individuals living in poverty in developing countries. Whenever I left the confinements of my walled-in, middleclass neighbourhood, I would be confronted with the reality of those who struggle daily to survive on minimum economic resources. Many of the dwellings surrounding my neighbourhood were self-built shacks, resulting in substandard and unsanitary living conditions. The inadequate construction techniques, which implemented an unrefined mix of permanent and temporary materials, created perilous buildings prone to structural failure. This deficient building method proved costly in January 2003, when a 7.8 Richter scale earthquake hit our city and levelled many of these types of informal dwellings throughout the city.

Such substandard living conditions are far from unique; the world is currently experiencing an unprecedented urban migration that is straining the resources and infrastructure of unprepared cities throughout the global south. Spontaneous and deficient squatter settlements, social class segregation, and the inequitable distribution of urban space and infrastructure have become staples of third-world cities.
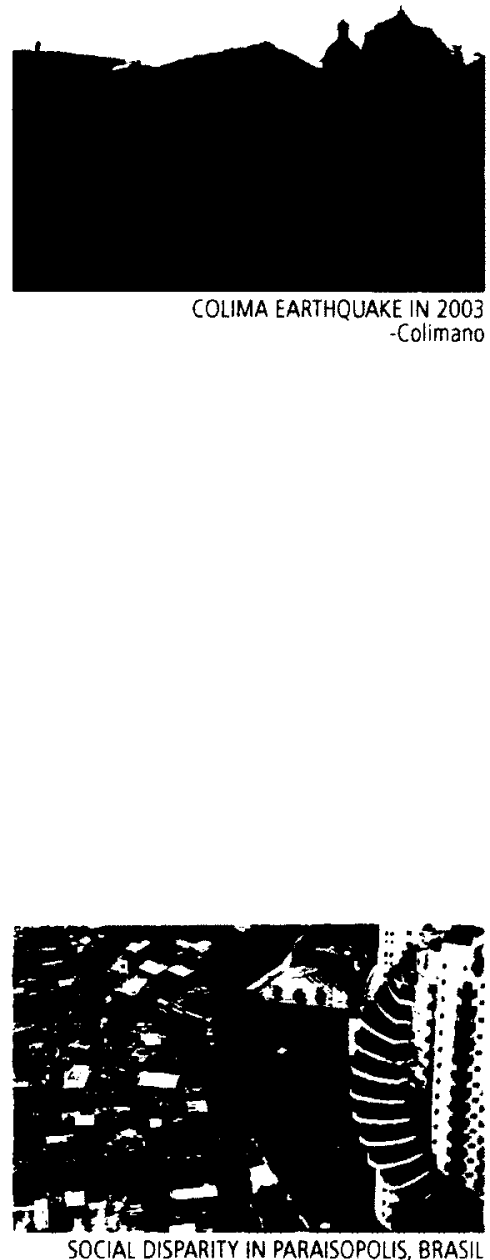

01 Marine, George. The New Global Frontier: Urbanization, Poverty and Environmem in the 2/st Century: London: Earthscan, 2008. 141. Print. 
The intention of this thesis is to examine the current and historical existence of squatter settlements and to explore the potential role architects can play within the informal context of these situations. The thesis will commence with a historical framework, placing squatters in historical and physical context and analysing the benefits and consequences they have on both the built and natural environment. Upon presenting a comprehensive introduction to challenges and potentials created by slums, the thesis will present a critical reflection on the current focus of the architectural profession and the importance of 'activist architectural practices' and the introduction of the 'social architect' to the professional field. In addition, the ways in which architects can act as agents of change, to work with squatters to improve their living conditions will be explored.

This thesis argues that one of the main restraints to the empowerment of squatters is the lack of information regarding potential approaches and solutions within their settlements. In response to this situation, an essential component to the thesis will be The Parachutist's Alternative, a document which will act as both an architectural project responding to the issues encountered in the informal settlement of Chimalhuacán, Mexico, and as a pamphlet that can be reproduced and distributed to squatters and community organizers within the settlement. The objective of this handbook is to provide squatters (or parachutists) with alternative solutions to the standard processes of regularization within informal settlements in Mexico City.
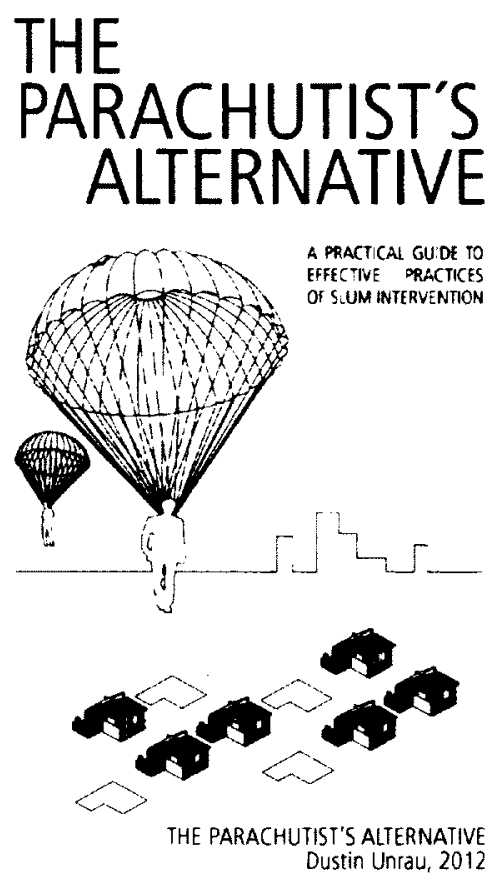

CAL GU:DE TO Dustin Unrau, 2012 


\section{INTRODUCTION}

\begin{abstract}
"Today it is necessary to make the Therapeutic Policy, which implies to consider the conditions of the coexistence; it is necessary to learn how to coexist, and in that sense, the favela teaches us."
\end{abstract} -Jacques Derrida ${ }^{A}$
For the first time in history, over half of the world's people are now living in cities. ${ }^{01}$ Even though cities generally offer more opportunities for growth and social mobility, in many third-world countries this transition is far from ideal. Upon arriving to the developing cities, new urban migrants are confronted with a lack of formal job opportunities, and an absence of formal housing that meets their poverty-stricken budget. New urban residents are consequently coerced into a life of the informal; taking up informal jobs and squatting under informal conditions.

The way in which governments deal with their new informal residents varies widely among third-world countries. Public policy can very well determine whether or not these informal settlements thrive or fail. For example, in cities such as Nairobi, squatters are restricted to marginal communities controlled by corrupt landowners that financially exploit the squatters and give them little opportunity to improve their deplorable living conditions. On the other hand, squatters in Rio de Janeiro managed to leverage some political clout, and benefit from governmental stances that have allowed them to secure tenure of their property and build permanent dwellings and infrastructure with little help or intervention from the authorities. ${ }^{02}$

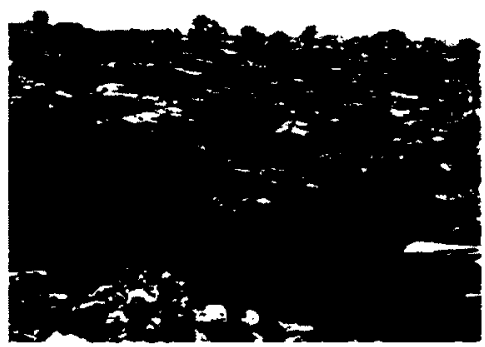

INFORMAL SETTLEMENT, KIBERA, NAIROBI - HenrY

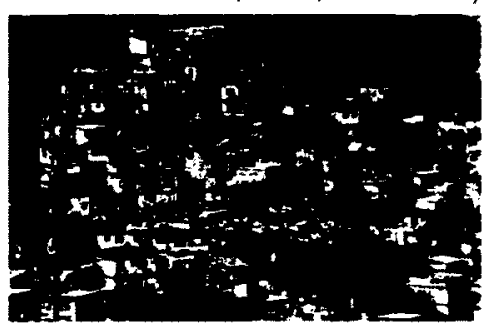

FAVELA, RIO OE JANEIRO - $\mathrm{N}$ Cabana

A. "MoMA I Small Scale, Big Change Manguinhos Complex." MoMA. Web. 25 Mar. 2012 $<$ http:/www.moma.org/interactives/exhibitions/2010/smallscalebigchange/projects/manguinhos complex>.

01. World Development Report 20199: Reshaping Economic Geograph: Washington, DC World Bank, 2009. Print.

02. Neuwirth, Robert. Shadow Cities: A Billion Squatters, a New Urban World. New York: Routledge, 2005. Print. 
Due to the extreme complexity of squatter communities, it is difficult to effectively identify, understand and address the problems interweaved within their intrinsic social, political and economic layers. Many governments have seen the disorder created by slums as an illness to their cities, and have tried to eradicate what they identify as a form of urban 'cancer', such as the American secretary of the National Housing Association Lawrence Veiller described in 1920 "The slum is exactly like a cancer in the human body. It can be cured by radium, if taken in time; but after it has gotten to a certain stage, it infects the body politic, and the only remedy for it is the surgeon's knife... and the sooner it is out, the less serious the operation. "03 However such removal or 'chemotherapy' hasn't worked. For instance, in 2005 the Zimbabwe government underwent an operation called 'Operation Murambatsvina' (Operation Drive Out Trash), which left hundreds of thousands of settlers homeless and unemployed. ${ }^{04}$ This operation was justified under the premise of stopping illegal activities such as vending, illegal structures and illegal cultivation. Zimbabwe's police commissioner, Augustine Chihuri, described Operation Murambatsvina as an effort to "clean the country of the crawling mass of maggots bent on destroying the economy." 05 However, in an effort to save a city's heart, or at least disguise the infirmity, these evictions simply spread the disease and disorder to the rest of the body (a city's periphery or vulnerable areas) where it is harder to control and treat the 'illness'. The displaced settlers of Harare as a result of Operation Murambatsvina are now walking up to $28 \mathrm{~km}$ ( 5 hours round-trip) every day to work, because the individual bus fare for one day now costs nearly a week's wages. ${ }^{06}$

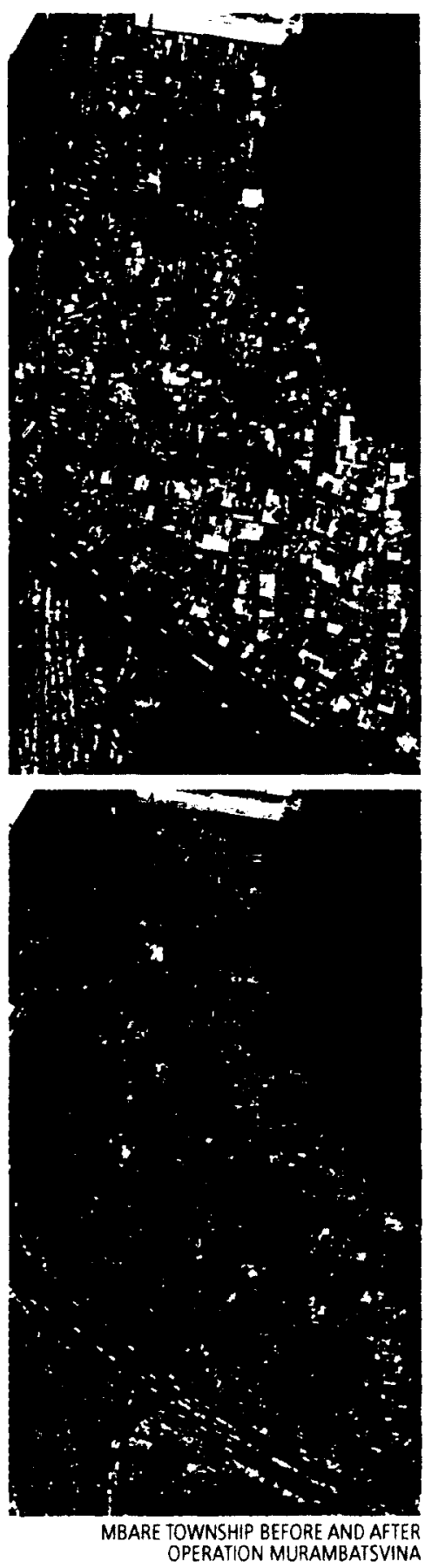

03. Fogelson, Robert. Downtown: Its Rise and Fall: 1880-1950. Yale UP. 2001. Print. P.349 04. Tibaijuka. Anna. Report of the Fact-Finding Mission to Zimbabwe to Assess the Scope and Impact of Operation Murambatsvina. Rep. United Nations, July 2005. Web. <http://ww2 unhabitat.org/documents/ZimbabweReport.pdf $>$.

05. "Priests Told: Don't Aid 'filth" " Sundan. Times (UK) 19 July 2005. Print

06. Timberg. Craig. "A Long. Hard Slog in Zimbabwe." The Washington Post 07 Feb. 2008 Print. 
On the other hand, many governments that allow informal settlements to develop freely can be confronted with consequences such as environmental degradation and social exploitation.

Certainly there isn't a simple solution to this seemingly insoluble situation. However, architecture's ability to identify, synthesize and elucidate complex issues can potentially enable architects to orchestrate an effective response to this impending problem. Though architects cannot single-handily change the economic system that is causing poverty, there is plenty of opportunites to imagine scenarios, explore alternative methods and practical approaches that could improve the living conditions encountered in slums.

Architects working in close collaboration with communities can help them act on their own behalf. In the words of Marie Aquilino, "Playing the roles of designer, historian, negotiator, and advocate, architects develop site alternatives that help secure land tenure, re-block overcrowded slums, afford better access to water, sanitation, air and light, introduce public spaces, and improve the relationship with the local ecology." 07 Architects can then represent community consensus on viable projects to intransigent or indifferent governments, and this, in turn, promotes local independence.

By misconceiving squatters as being unorganized, dirty, and parasitical, it appears there will never be a successful solution to the issues they continually confront, or to the problems they create upon a city. As architects, how should we face the inherent challenges of these informal settlements? How can we work in, and treat squatter settlements as

07. Aquilino. Marie Jeannine. Bevond Shelter: Architecture and Human Dignit!: Neu York. NY: Metropolis, 2010. Print. P. 9.

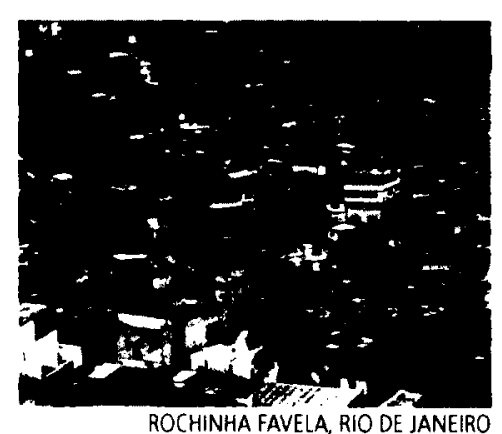

ROCHINHA FAVELA, RIO DE JANEIRO . 
places of creative potential and opportunity? And why would we do this? Perhaps for simple but not obvious reasons as described in the words of the Sogyal Rinpoche, "The constant uncertainty may make everything seem bleak and almost hopeless, but if you look more deeply at it, you will see that its very nature creates gaps, spaces in which profound chance and opportunities for transformation are continuously flowering if they can be seen and seized." 08

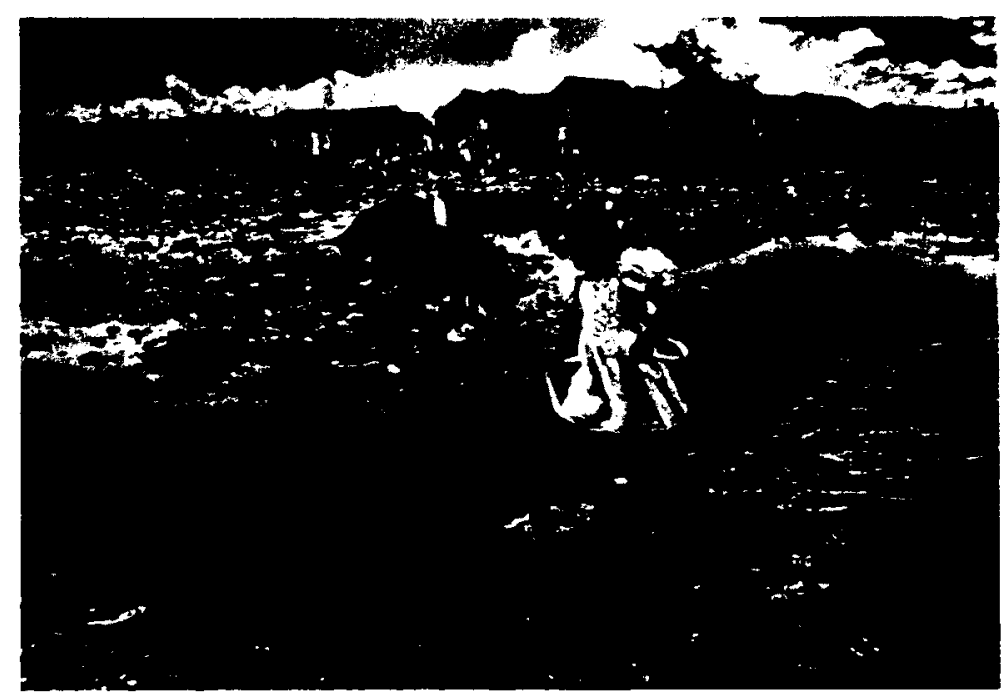

SLUM IN HAITI - Alice Smeets 


\section{SQUATTERS IN CONTEXT}

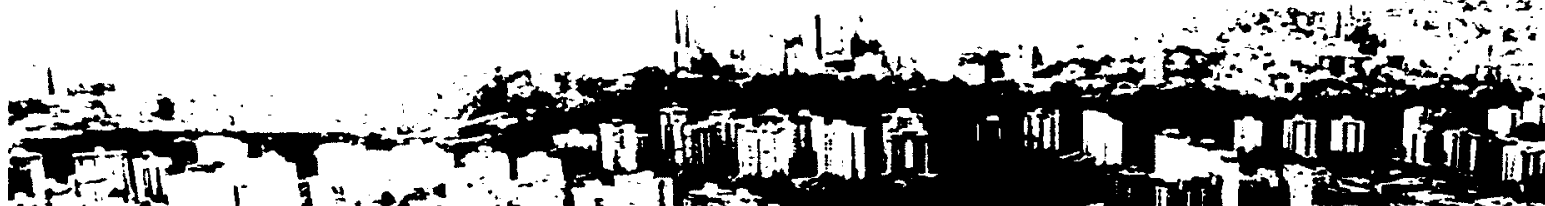

Non 140

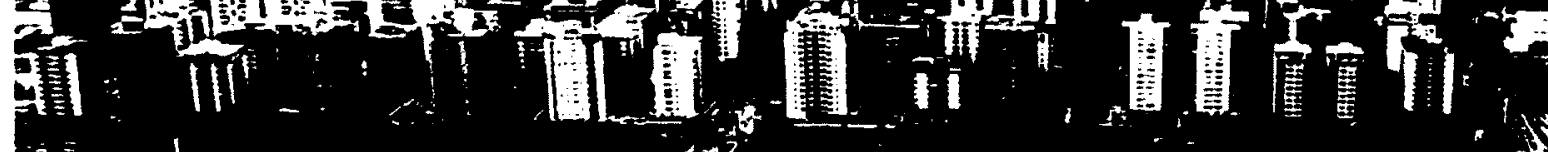

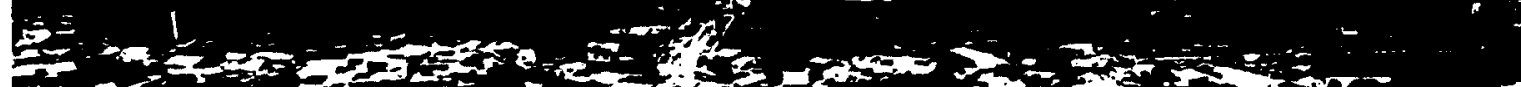

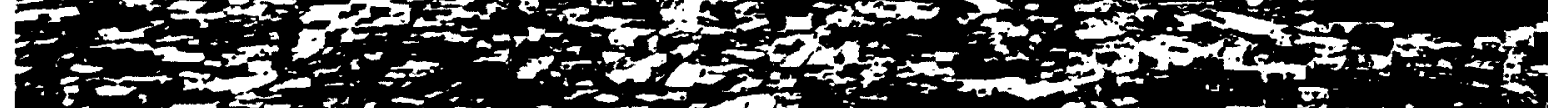

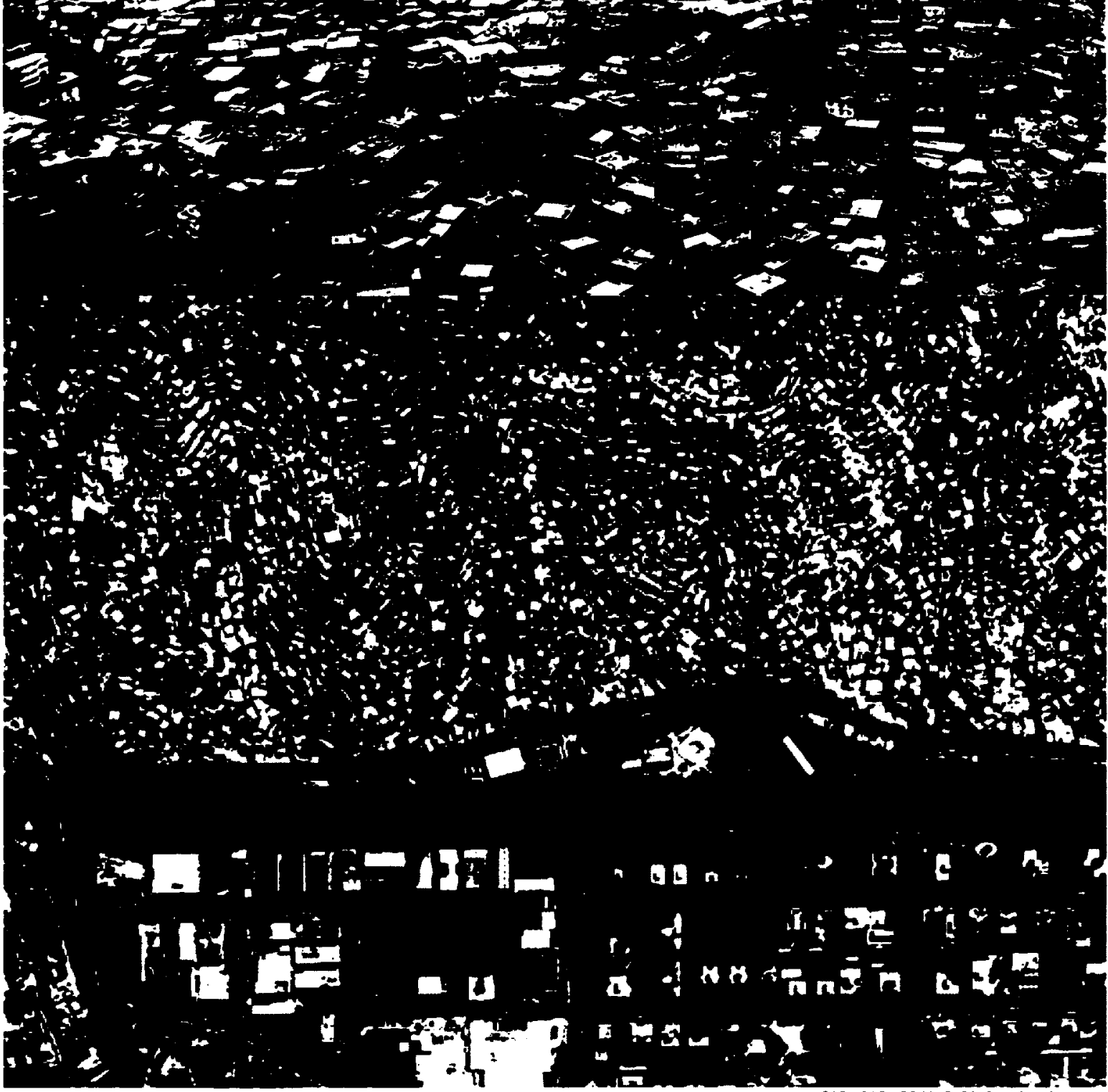




\section{SQUATTERS IN CONTEXT}

"One person's slum is another person's community."

May Hobbs ${ }^{A}$
There are presently over one billion slum-dwellers squatting in the cities of developing countries throughout the world. ${ }^{01}$ With the substantial global immigration currently taking place, by 2050 this figure is expected to triple to over 3 billion squatters living in illegal settlements with little to no legal rights and constrained access to public services. ${ }^{02}$ Growth in squatter communities has long outpaced growth of formal communities in the global south. Without doubt, squatters are building the cities of tomorrow. The way they shape and alter their surrounding environment will have a tremendous impact on future global development and its built context. Will the future of cities look like Kibera - where about a million people live in unsanitary huts of mud and corrugated metal? Or will they resemble the consolidated settlements of Istanbul - where the economy is growing and most informal settlers have access to public services? $?^{03}$

The UN 2009 Population revision confirmed that the world population is currently more urban than rural and that urban migration is rapidly increasing. Between 2009 and 2050, the world population is expected to increase from 6.9 billion to 9.1 billion. At the same time, the population living in urban areas is expected to increase from 3.4 billion in 2009 to 6.3 billion in $2050 .{ }^{04}$ As a result, rapid urban growth in the context
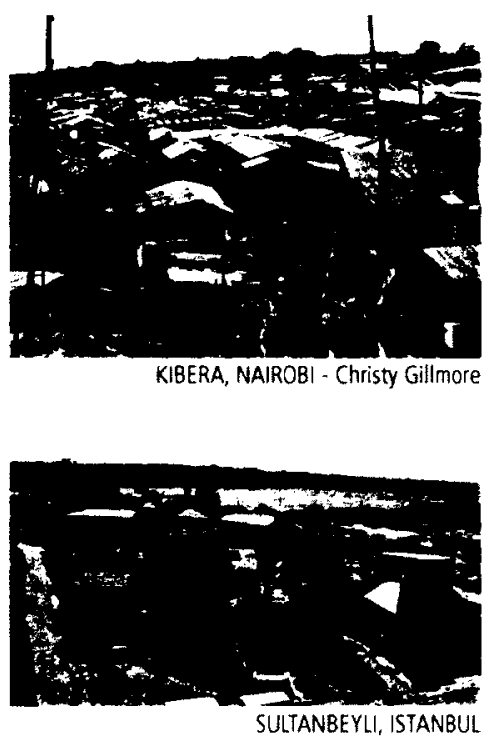

\footnotetext{
A. Hobbs, May. Bom to Struggle. Plainfield. VT: Daughters, 1975. Print.P. 2

01. Sutherland. Ben. "BBC NEWS In Depth Slum Dwellers 'to Top 2 Billion" BBC News Home. Web. 06 Feb. 2012. <http://news.bbc.co.uk/2/hi/5099038.stm>

02. Alex Steffan, World Changing: A User's guide for the 21" Century, Abrams, New York. 2006. Pp. 286-287.

03. Tuhus-Dubrow, Rebecca. "Leaming from Slums." Boston Globe I Mar. 2009. Print.

04. United Nations Department of Economic and Social Affairs/Population Division. World Urbanization Prospects: The 2009 Revision. p.11.
} 
of structural adjustment, currency devaluation, and state cutback has inevitably produced slums on a massive scale. The International Labour Organization estimated that the formal housing markets in the Third World rarely supply more than 20 percent of new housing stock. Out of necessity, people turn to self-built shanties, informal rentals, pirate subdivisions, or the sidewalks. ${ }^{05}$ Since 1970 , urbanization has been outpaced by slum growth everywhere in the global south.

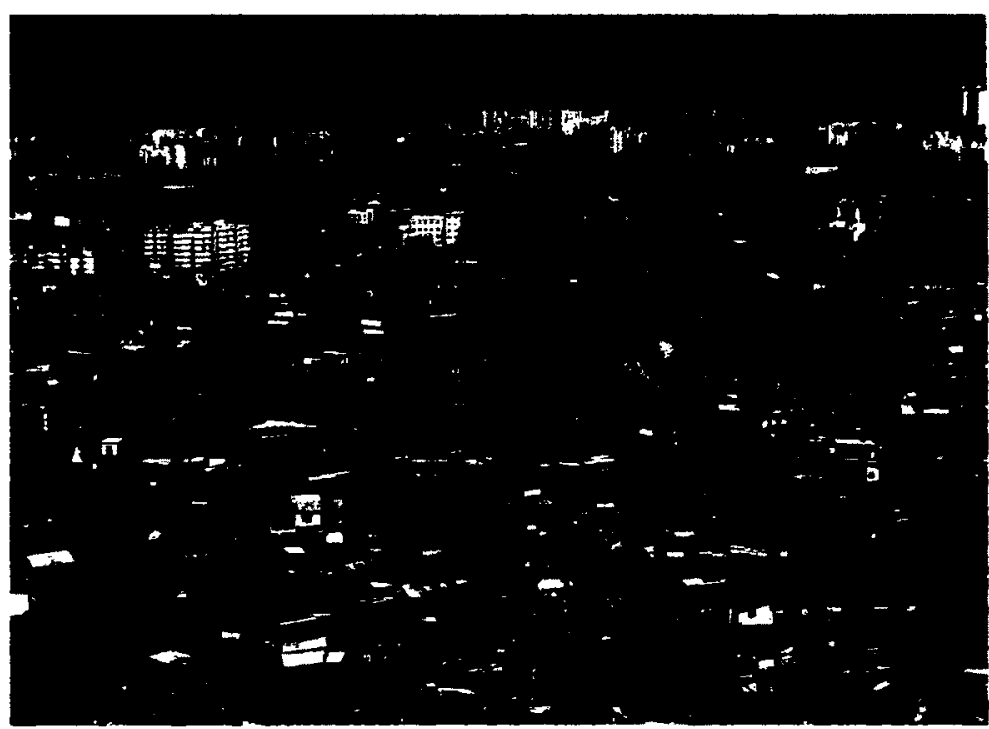

MUMBAI SLUM -Joel Newell

Mike Davis points out in his book 'Planet of the Slums' that Classical social theoreticians such as Karl Marx and Max Weber believed that the great cities of the future would follow in the industrialized footsteps of Manchester, Berlin and Chicago. ${ }^{06}$ Indeed some cities such as Ciudad Juarez and Bangalore have followed this trajectory. However, according to Davis, most cities of the south more closely resemble Victorian Dublin, which was unique amongst the slumdoms produced in the western world of the nineteenth century, being that it was not a product of the industrial
Slums, according to UN-Habitat (2003), are highly congested urban areas marked by deteriorated, unsanitary buildings, poverty, and social disorganization. Squatters settle on land, especially public or unoccupied land, without right or title. Squatters include those who settle on public land under regulation by the government, in order to get title to it. Slums refer to the environmental aspects of the area where a community resides, while squatters refer to the legality of the land ownership and other infrastructure provision. -UN-Habitat (2003), Op. Cit.

05. UN-HABITAT, An urbanising World: Global Report on Human Settlements, Oxford 1996, p. 239.

06. Davis, Mike. Plunet of Slums. London: Verso, 2006. Print., p.16 
revolution. ${ }^{07}$ As Davis notes, the cities of the future are not made out of glass and steel as envisioned by earlier generations of urbanists and theoreticians; instead, they are largely constructed out of crude brick. straw, recycled materials, cement blocks, and scarp wood. ${ }^{08}$ Instead of urban utopias, the current urban third-world squats in rubbish and decay.

Urban migration in the global south has continued despite falling real wages, soaring prices, and growing urban unemployment. This perverse economic boom surprised most experts and contradicted orthodox economic models that predicted that the negative feedback of urban recession would slow migration from the countryside. ${ }^{.9}$ in Africa for example, many urban economies were contracting by 2 to 5 percent annually while the population in those cities was growing 4 to 8 percent. ${ }^{10}$ According to UN-Habitat, Bombay, with 10 to 12 million squatters and tenement-dwellers, is currently the global capital of slumdwelling, followed by Mexico City and Dhaka ( 9 to 10 million each)." Such mega-slums arise when shantytowns and squatter communities merge in continuous belts of informal housing and poverty, usually on the urban periphery. For example, in 1992 Mexico City had an estimated 6.6 million low-income people living in contiguously 348 square kilometers of informal housing. ${ }^{12}$ Mexico City perhaps best epitomizes the struggles of both developed and developing countries, in that along with its vast landscapes of informal settlements it is also characterized by a massive urban sprawl. Such development could eventually incorporate periphery cities into a single megalopolis that could potentially have a population of about 50 million people by mid-twenty-first-century. ${ }^{13}$

07. Davis, Mike, Ibid., p.19

08. Ibid. p. 19

09. Ibid. p.17

10. Ibid. p. 17

11. UN-HABITAT, "Slums of the World: The Face of Urban Poverty in the New Millenium?," Nairobi 2003, annex 3 .

12. Keith Pezzoli, Human Settlements and Planning for Ecological Sustainability: The case of Mexico City, Cambridge 1998, p.13.

13. Gustavo Garza, "Global Economy, Metropolitan Dynamics and Utban Policies in Mexico," Ciries 16:3(1999), p. 154 .

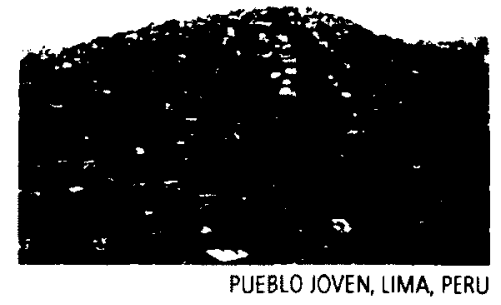

There is no universal name for squatter settlements, in Brasil they are called Favelas, in Turkey, Gecekondu, in Peru, Pueblos Jovenes, in Colombia, Callampas, in Indonesia Permukiman liar, in Mexico Colonias Populares or Paracaidistas and in French colonies they are named Bidonvilles. 
In fact, the majority of the world's urban poor no longer live in inner cities. Since 1970 the larger share of world urban population growth has been absorbed by slum communities on the periphery of Third World cities. Sprawl has ceased to be a distinctively North American phenomenon. The "horizontalization" of poor cities is often as astonishing as their population growth. In sprawling cities of the Third World, "periphery" is a highly relative, time-specific term: today's urban edge may tomorrow become part of a dense metropolitan core. ${ }^{14}$

This collision between the rural and the urban has resulted in a mixed landscape that Gregory Guldin argues may be "a significant new path of human settlement and development... a form neither rural nor urban but a blending of the two wherein a dense web of transactions ties large urban cores to their surrounding regions." ${ }^{15}$ German architect and urban theorist Thomas Sieverts proposes that this diffuse urbanism, which he calls Zwischenstadt ("in-between city"), is rapidly becoming the defining landscape of the twenty-first century countries. ${ }^{16}$

\section{PREVIOUS APPROACHES}

\section{EVICTION}

One reason why squatter settlements have sprawled out from the city core is because, from a politician's point of view, slums damage the public image of a city, leading to continuous evictions to remove them from the public view. Usually these evictions occur under the name of "beautification," "progress," or "social justice". ${ }^{17}$ Governments intervene and forcefully relocate these urban squatters. Some metropolitan governments such as

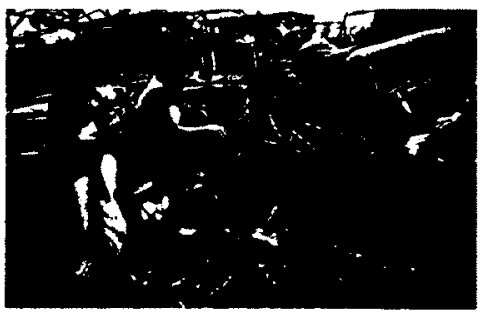

CHARCOAL COLLECTORS - MANILA - Hannah Reyes

In the Philippines fire demolition is the mostcommon technique employed by Filipino landlords, where they chase burning cats or rats into an annoying settlement, setting enough shanties on fire in order to provoke massive destruction before the animal dies. ${ }^{.}$

b. Erhard Berner, Defending a Place in the City: localities and the struggle for urban land in metro Manila. University of Hawaii Pr., 1998. p. 144

\footnotetext{
14. Davis, Mike. Op cit, p. 37

15. Gregory Guidin. What's a peasant to do? , Westview Press, Boulder, 2001, Pp. 14-17.

16. Thomas Sieverts, Cities without cities: an interpretation of the Zwischenstadt, London 2003, p. 3.

17. Davis, Mike. "Haussmann in the Tropics." World-Information. Org. Web. 06 Feb. 2012. <htt: /world-information.org'wio' readme/992003309/1154965269>.
} 
Cairo, Mumbai, Delhi and Mexico City built satellite cities to induce poor residents to relocate to the periphery. In most cases, these new cities only attracted more migration from the adjacent countryside or middleclass commuters. ${ }^{18}$ Such evictions are rarely peaceful. Governments and developers have continuously been guilty of risking the squatters' safety in the attempt to remove them from their community.

\section{PUBLIC HOUSING}

Another common approach to alleviate the problems associated with slums is the implementation of public (social) housing strategies. In Mumbai for example, any squatter family that owns its structure and can prove that it has been there since 1995 , will be given a home at no cost if their community is targeted for a government-aided project. Developers in Mumbai can also qualify for a valuable zoning bonus if they build replacement housing for squatters. Although this "free" housing can be beneficial, it is not always the best approach. When squatters feel secure in their homes, they will invest and improve their neighbourhoods. But if they simply have a small apartment in a high rise building that they don't control, they lose that incentive. Their communities cease to develop. Also, the policy does nothing for the poorest squatters who are only tenants in the squatter communities. If their community elects to participate in one of these plans, they are stuck homeless. ${ }^{19}$

One of the main problems with public housing is that there is rarely room for future expansion. The people in the slums now know that eviction and life in these flats would reduce their means of reproduction and the possibilities for subsistence production. Furthermore, access to work is usually more difficult due to the peripheral location of these flats. Many

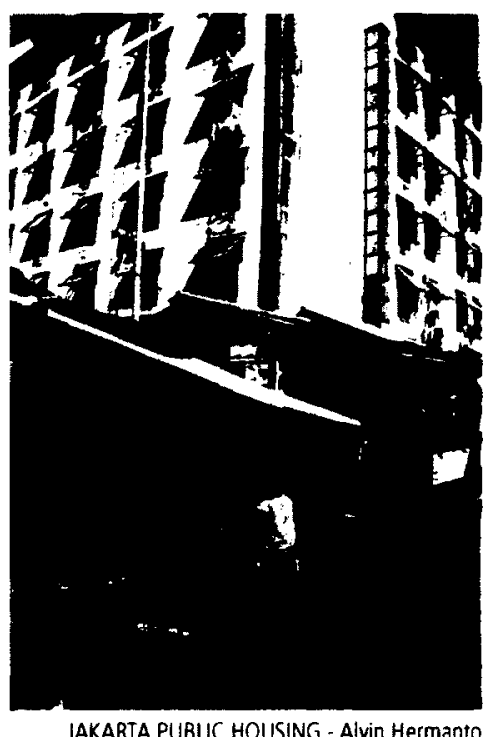

In Jakarta, public housing is unattractive to the huge informal labour force because it provides no space for home workshops. 
slum-dwellers prefer to stay in the slum and are starting to fight against relocation to public housing buildings. For them the slum is the place where production and resilience under deteriorating circumstances is still possible. $^{20}$

Another issue with public- and state-assisted housing in the Third World is that it has primarily benefited the urban middle classes and elites, who expect to pay low taxes while receiving high levels of municipal services. In a comparative study between ten Third World cities, Nick Devas found little evidence of any serious effort to assess and collect property taxes from the affluent. ${ }^{21}$ Likewise, in Egypt, Ahmed Soliman found that "public investment (for housing) has been largely wasted," with the result that "about twenty million people live today in houses that are detrimental to their health and safety".22

\section{TITLING}

Frustrated with the situation of public housing, John Turner, an Architect interested in housing for the urban poor, suggested the best way to improve squatter communities was to let the residents build it themselves. Turner was an effective propagandist who proclaimed that slums were less the problem than the solution and his core program of self-help, incremental construction and legalization of spontaneous urbanization was the programmatic, cost effective approach to the urban crisis that was eventually appropriated by the World Bank with mixed measures of success.

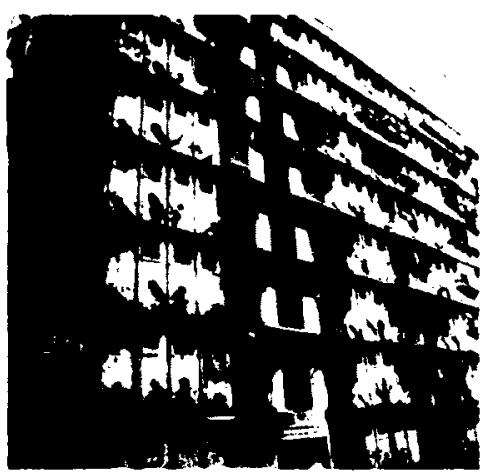

DHARAVI PUBLIC HOUSING, MAHARASHTRA,INDIA

20. Evers and Korff, Southeast Asian Urbanism, p. 168.

21. Nick Devas, "Can City Governments in the South Deliver for the Poor?" International Development and Planning Review 25:1 (2003), pp. 6-7.

22. Soliman, in Ananya Roy and Nezar Al Sayyad (eds), Urban informality: Transnationa! Perspectives from the Middle East, Latin America, and South Asia, Lanham (Md.) 2004, p. 171. 
Despite the lack of profound success of the World Bank programs, Peruvian economist Hernando de Soto agrees with Turner's point of view and is optimistic about the potential that squatter settlements have. De Soto asserts that Third World cities are not so much starved for investment and jobs as suffering an artificial shortage of property rights. ${ }^{23} \mathrm{He}$ argues that the poor aren't really poor; they are just unable to access their wealth or turn it into liquid capital because they do not possess formal deeds or property titles. De Soto claims that by titling, an instant massive equity would be created with little to no cost to the government. This capital would supply micro-entrepreneurs to create new jobs in the slums and shantytowns would provide trillions of dollars if they could find a way to transform assets into capital. ${ }^{24}$

However, de Soto's theory is contested by Geoffrey Payne, a British urban planning consultant who points out that while titling would officially incorporate owners into the city, it would push tenants off the housing ladder altogether because they wouldn't be able to afford the incremental expenses. Titling according to Payne, accelerates social differentiation in the slum and does nothing to aid renters, who are really the worst off. ${ }^{25}$

\section{THE ISSUE OF INEQUALITY}

Perhaps the main argument surrounding squatter developments is related to property rights and titling. The issue lies within the conflict between formal and informal mindsets; squatters don't view land in the same way that the rest of society views it. According to Robert Neuwirth, instead of viewing land as en economic notion, squatters assume that every person has a natural right, simply by the virtue of being born, to have a home,

23. De Soto, Hemando, The mystery of Capital: Why capitalism triumphs in the west and fails everywhere else, New York 2000, pp. 301-310.

24. De Soto, Hernando, ibid. pp. 301-310

25. Alan Gilbert and Ann Varley. Landlord and tentant: Housing the Poor in Urban Mexico, London 1991, p.4

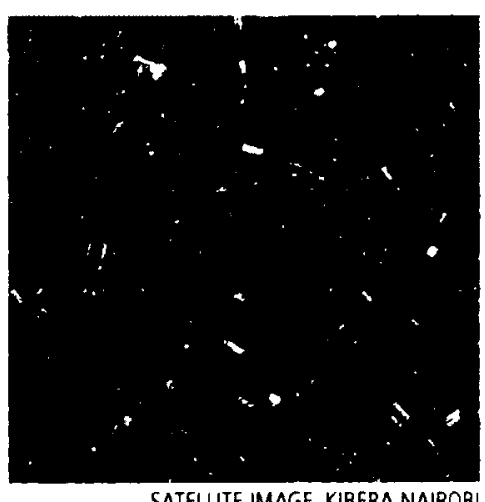

SATELLITE IMAGE, KIBERA NAIROBI

Population density is one of the easiest ways of measuring the inequality that exists in such cities. For example, the suburb of Karen in Nairobi has fewer than 360 inhabitants per square kilometer, while parts of Kibera have more than 80,000 people in the same sized area. In Bombay, according to some researchers, $90 \%$ of the city's land is owned by the rich, while the poor are crushed into the remaining $10 \%$ of land.

- O'Hare, Abbott, and Barke, "A review of $5 /$ um Housing Policies in Mumbai." $p .276$ 
a place a location in the world. Their way of dealing with land questions what really entails socially just city. ${ }^{25}$

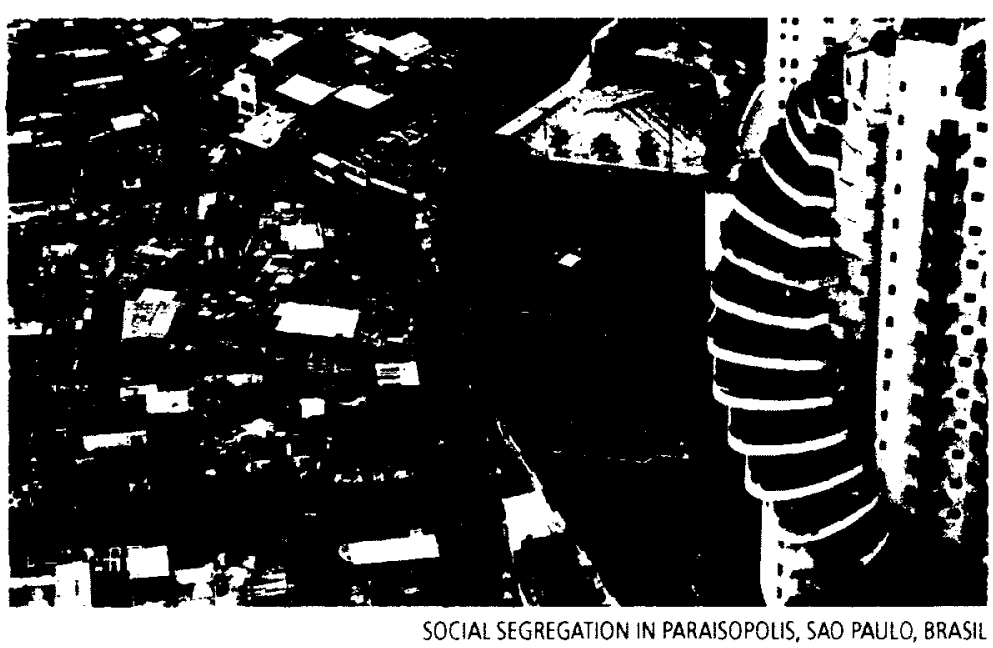

Neuwirth points out that, though property is the basis of the western system that has undeniably grown wealth and comfort; no one has been able to come up with a convincing justification for it. Jean Jacques Rousseau, in the Discourse of the origin of Inequality, published in 1755 , stated the following objection to what was happening at a time when the British aristocracy fenced in and grabbed much of the land that had historically been held in common throughout England.

"The true founder of civil society was the first man who, having enclosed a piece of land, thought of saying, 'This is mine,' and came across people simple enough to believe him. How many crimes, war, murders and how much misery and horror the human race might have been spared if someone had pulled up the stakes or filled in the ditch, and cried out to his fellows: 'Beware of listening to this charlatan. You are lost if you forget that the fruits of the earth belong to all and that the earth itself belongs to no one."'27

\footnotetext{
26. Neuwirth. Robert. Op Cit, p.12

27. Rousseau, Jean-Jacques, and Immanuel Kant. Rousseau: On the Origin of Inequalin: Vol. Part II. Chicago: Great Foundation. Print.
} 
The debate continues. Gita Verma suggests that, indeed, the root cause of urban slumming seems to lie not in urban poverty, but in urban wealth. ${ }^{28}$ Squatters have proven to bring big benefits to landlords and developers. Overcrowded, poorly maintained slum dwellings are often more profitable per square foot than other types of real-estate investment. In Sao Paulo for example, cortico rent price per square meter is around 90 percent higher than in the formal market. ${ }^{29}$ Squatters have also been known to be used by landlords as urban pioneers, they turn barren hillsides and swampy marshes into housing land, and then the owners evict them or raise their rents with the increase in land value. ${ }^{30}$

The sparse amount of land that squatters are able to claim is usually in undesirable, hazardous and health-threatening locations. They trade physical safety and health for security against eviction. According to geographer Kenneth Hewitt, over 100 million homes were destroyed during the twentieth century due to earthquakes, mostly in slums, tenement districts, or poor rural villages. In fact, the term "classquake" was made in order to characterize this biased pattern of destruction. ${ }^{31}$

\section{ENVIRONMENTAL IMPACT}

Squatter settlements have negatively impacted both their immediate ecology and large-scale environments. Third World countries generally pollute, urbanize and destroy the crucial environmental support system of wetlands and agricultural fields surrounding their urban conglomerations. Slums have invaded ecological sanctuaries and protected watersheds, 
poisoning sources of drinking water such as is the case with Mexico City's essential ecological buffer, the Ajusco recharge area. In fact, experts estimate that over 90 percent of Latin America's sewage is dumped untreated in streams and rivers. ${ }^{32}$ Waterborne sewage systems are limited in slums. In India for example, an estimated 700 million people are forced to defecate in the open, and only 17 of 3700 cities have any kind of primary sewage treatment before final disposal..$^{33}$ The health concerns that evolve from this practice are extremely serious. Digestive-tract diseases arising from poor sanitation and the pollution of drinking water are the leading cause of death in the world, affecting mainly infants and small children. ${ }^{34}$

Even though clean water is the cheapest and single most important medicine in the world, public provision of water often competes with powerful private interests. In Nairobi for example, politically connected entrepreneurs resell municipal water in the slums at mushroomed prices. In fact, a study shows that the population of the Kibera slum pays up to five times more for a litre of water than American citizens. ${ }^{35}$

\section{MISCONCEPTIONS}

Robert Neuwirth doesn't see slums as a lost cause. Neuwirth believes that, given the chance, slums will improve themselves and create an economy. According to Neuwirth, the true challenge of such communities should not be to eradicate them, but to stop treating them as horrific, scary and criminal, and instead start treating them as neighbourhoods

\footnotetext{
32. Imparato and Ruster, Slum upgrading and participation, p.61.

33. Davis, op cit. p 139.

34. Nikhil Thapar and Ian Sanderson, "Diarmoea in Children: an Interface between Developing and Developed Countries," The Lancer 363, (February 2004), pp. 641-50 35. Intermediate Technology Development Group (ITDG) East Africa Newsletter (August
2002).
}
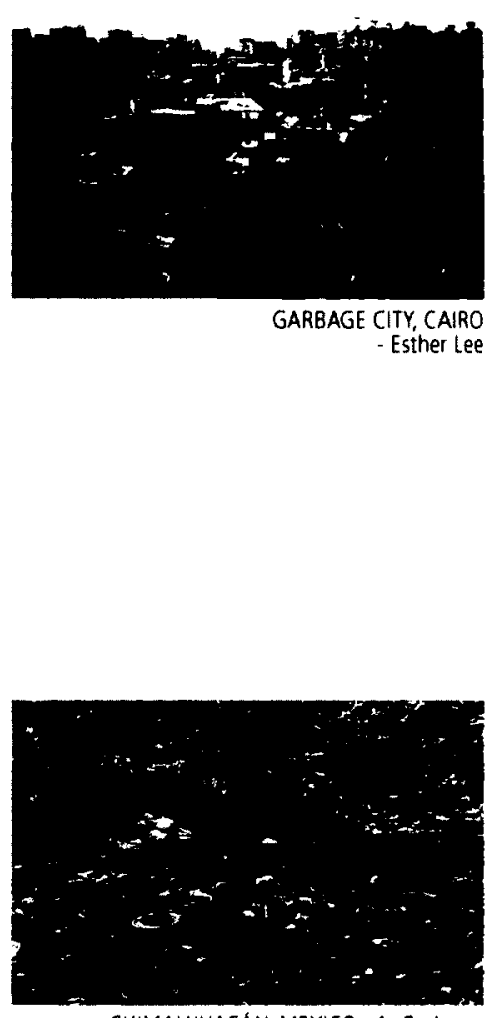

CHIMALHUACAN, MEX|CO-A. Gutierrez Open air garbage pits and clandestine waste sites are a serious environmental concern in Chimalhuacán, Mexico. 
that can be improved. They don't need to be knocked down and built new, because in most cases this will only produce housing that is not affordable to the people who are living there. In order to make a difference in these communities, organizations have to work with the squatters. "Squatters are interested, hard-working, and responsible adults. They can make decisions for their communities. They can define the trade-offs that will be acceptable. And without them, any work to upgrade their communities will be doomed to fail." 36 Unfortunately, there is a wide misconception that squatters are neglectful, criminal and intransigent. Such misconceptions can often interfere with improvement efforts.

The real problem in slums, according to Neuwirth, is corruption. "Communities like Kibera seem to exist principally because of corruption. Anything you want to do in the community, from building a house to making a serious repair, the civil servants from the provincial administration insist on payoffs. If you don't pay them off, they will knock down anything you build or call the police to inspect your business." In Neuwirth's point of view, Kibera is not a mud hut city because of its people. It remains mired in the muck because the system denies the residents control over their future. Corruption and profiteering keep it this way. One resident explained their predicament the following way: "The government claims the land is forest. When they come to ask for votes from the forest, we are suddenly changed from trees to people. But, legally, we are just trees." ${ }^{37}$ According to Neuwirth, many of the non-profit entities that exist around the community are also involved in corruption. There are water purifying organizations that don't purify any water, health clinics that don't have any doctors and schools that teach children in deplorable conditions while making a large profit off of them. Many people can get rich by forming a non-profit. The income comes first, the doing well is secondary. These

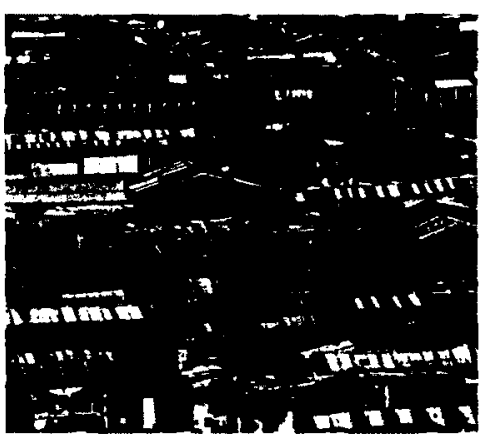

ROOFTOPS OF KIBERA, NAIROBI - 5. HenNY 
stories of corruption are part of the everyday life of these communities.

UN-Habitat's global report on human settlements 'The Challenge of the Slums' summarized the current urban situation with the following: "Instead of being a focus for growth and prosperity, cities have become a dumping ground for a surplus population working in unskilled, unprotected and low-wage informal service industries and trade." 38 According to UN-Habitat, informal workers constitute about two-fifths of the economically active population of the developing world. ${ }^{39}$

However, despite the many serious problems that come tied to this unprecedented slum growth, there are many positive aspects that can be found in the midst of squatter settlements. Squatter communities are the most dynamic parts of the fastest-growing cities in the world. They are self-built, self-designed, and self-motivated..$^{40}$ Though there are generally few formal jobs throughout squatter communities, everybody works in one way or another, and although squatters are supposed to have no money, some squatter cities such as the favelas in Brasil or certain colonias paracaidistas in Mexico City have thrived and local businesses and legal services have sprouted within these illegal communities.

It is possible that slums will never be eradicated and will remain to be a problem for future generations to come. However, when looking at squatter settlements that have resiliently overcome their greatest problems and now provide a permanent shelter and an economy to sustain themselves and their families, slum improvement through the means of architectural agency and community activism seems achievable.

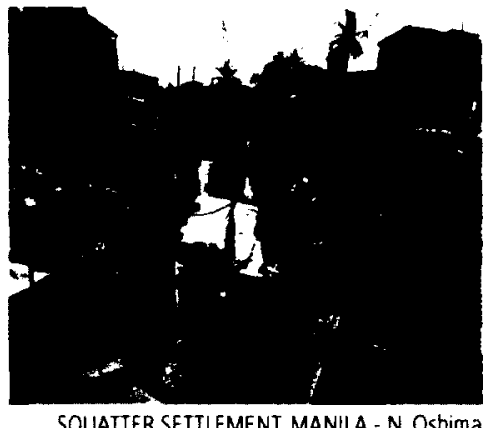

SQUATTER SETTLEMENT, MANILA - N. OShima

38. UN Habitat. The Challenge of Slums: Global Report on Human Setlements, 2003. London: Earthscan, 2003. 40-46, Print.

39. UN Habitat. Op cit.

40. UN Habitat. Op cit. 


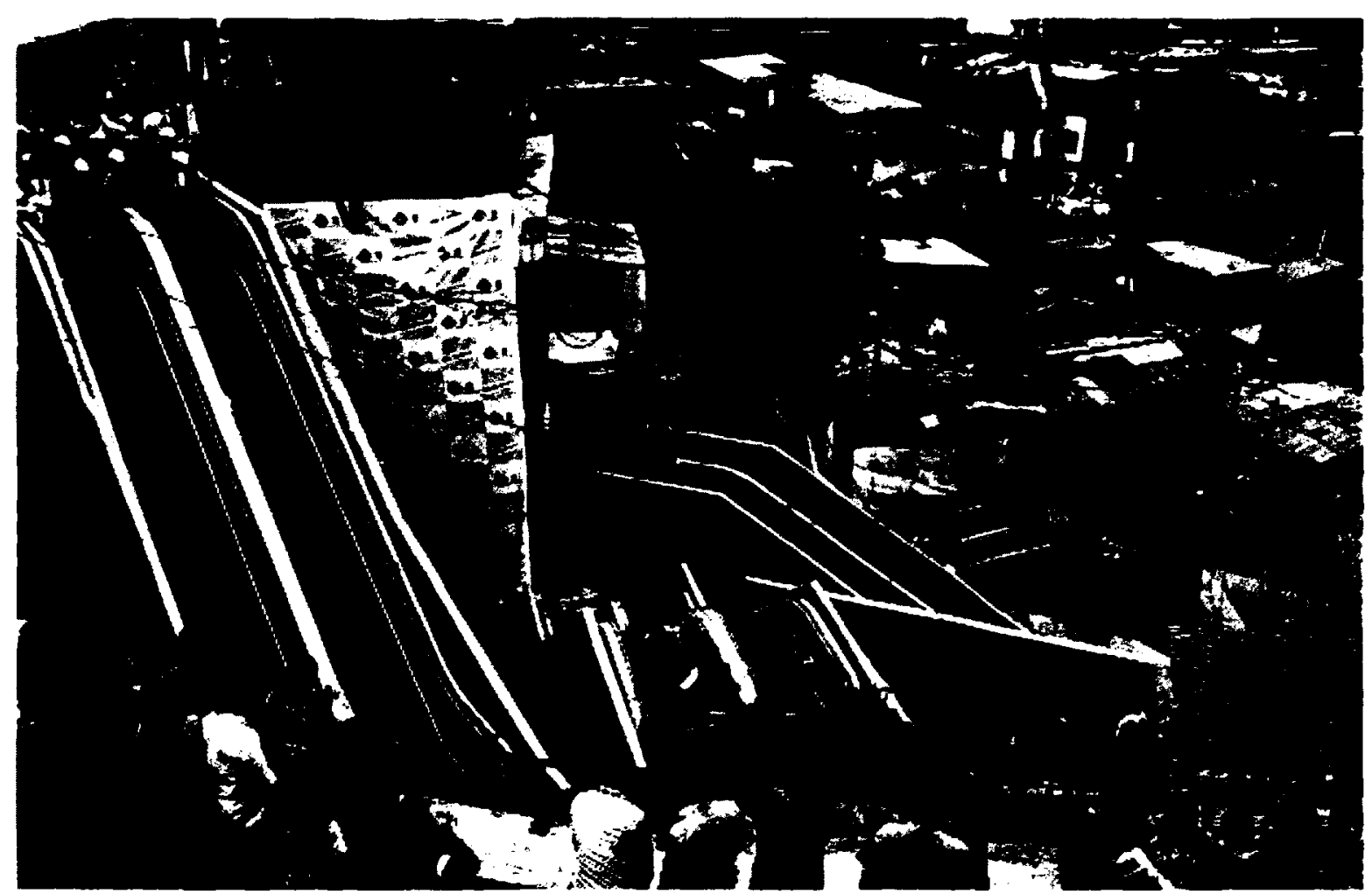

ELECTRIC STAIRS IN MEDELLIN, COLOMBIA, 2012 - G. Restreppo

A new electric stairway project that communicates the Comuna 13 slum in Medellin, Colombia with the rest of the city has been well received by local residents since it vastly improves transportation efficiency and communication within the hillside settlement. 


\section{SLUM ARCHITECTURE}
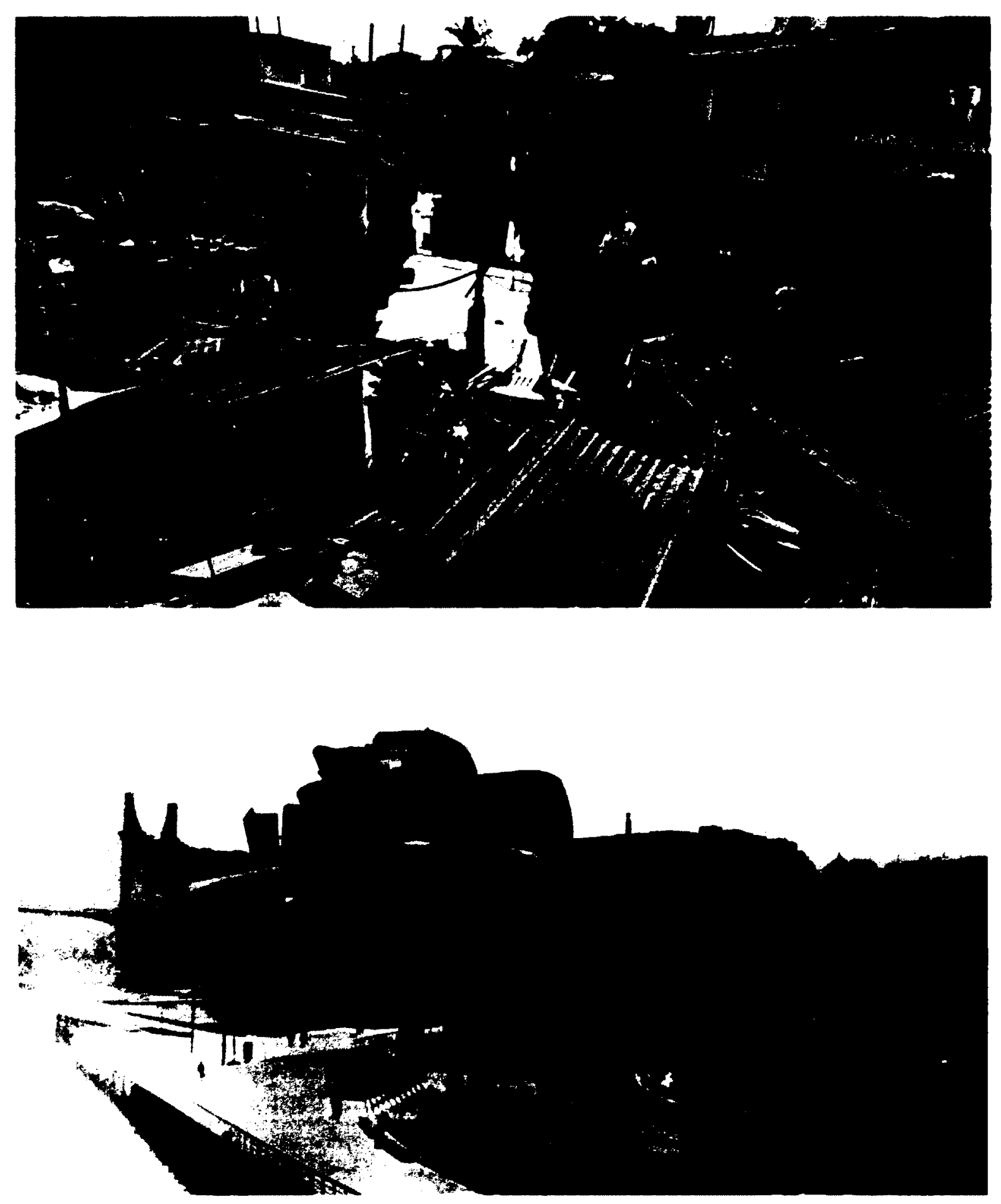

HYPER AESTHETICS 


\section{SLUM ARCHITECTURE / HYPER AESTHETICS}

"We are living in the waning hours of the mythology of the architect. By definition, the architect is an agent of change. Architecture can never be passive and there is strong intolerance for our profession when we cannot provide any answers - and perhaps worse, when we do not even claim any answers."

- Rem Koolhaas ${ }^{0}$

Despite the ever-increasing global social disparity, architects continue to act with little regards to an extended social agenda. Instead, as Teddy Cruz describes, architects are engaged in a practice of self-referential apolitical formalism leaving the poor to provide their own architecture and plan their own infrastructure and public spaces. ${ }^{01}$

Though it is difficult to determine a specific figure, the advocacy treatise 'Expanding Architecture: Design as Activism' suggests that approximately $98 \%$ of the buildings worldwide are designed and built without an architect. ${ }^{02}$ Perhaps the most compelling evidence of this phenomenon of disparity within the architectural realm is encountered through the inception of the 'starchitect' neologism - an awkward fusion of a star and an architect. This celebrity status is a direct product of the commercialization of architecture to a system of economic excess, which has created cities such as Dubai, considered by some as more a montage than an honest metropolis. ${ }^{03}$ This self-referential disconnect in the architectural profession has resulted in the creation of architecture for the sake of architecture and, as Teddy Cruz describes, hyper-aesthetics for the sake of aesthetics, which continues to press the notion of the avantgarde as an autonomous discourse. ${ }^{04}$

\footnotetext{
0. Koolhaas, Rem. "In Search of Authenticity." The Endless City: The Urban Age Project By Richard Burdett and Deyan Sudjic. London: Phaidon, 2007. Print.

01. Cruz, Teddy. "Design Ops." Architecture at the Edge of Everthing Else. Ed. Esther Choi and Marrikka Trotter. Cambridge. MA: Work. 2010. 74-84. Print.

02. Bell, Bryan, and Katie Wakeford. Expanding Archirecnure: Design as Acrivism. New York Metropolis, 2008. Print.

03. Prat. Ramon. "Dubai: Global City Guaranteed?" Verb Crisis. Barcelona: Actar, 2008. Print

04. Cruz, Teddy. "Design Ops." Op. Cit.. 74-84.
}

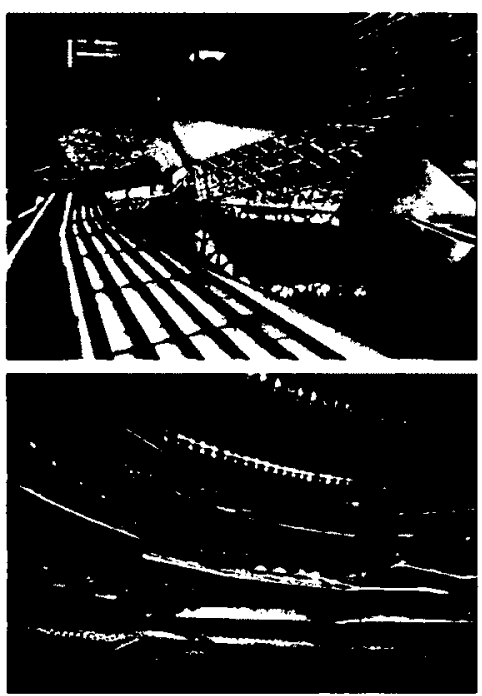

GUANZHOU OPERA HOUSE - Christian Richters

Zaha Hadid's Guanzhou Opera House, an example of the search for pure architecture and a detached formal experimintation. 
Michael J. Lewis considers the emergence of this international celebrity culture as "the most important development in the architectural profession in a generation, and we have scarcely begun to take its measure." 05 Lewis' viewpoint is deeply alarming considering that this generation has also experienced an unprecedented urban flux that is straining third-word sustainability, whilst being overly concerned with formal and technical experimentation.

Patrick Coulombel, director of Architectes de L'Urgence, believes that it is "ethically appalling" that architects remain uninterested in, and out of touch, with building for the most vulnerable and impoverished people... "We must not forget that the foundation of our métier is to provide all people with a decent place to live. Too few among us (and I am thinking particularly of the "star" architects who command the world's attention) have taken the time to consider the questions and challenges of emergency architecture." 06

The archetype of the celebrity status, Frank Lloyd Wright, was once asked by a young student for a book recommendation. The answer: "Read Emerson's essay on 'Self-Reliance."' The student, embarrassed that the elderly architect had misunderstood him, clarified that he was asking specifically for an architectural book. This time the answer was testy: "Read Emerson's essay on 'Self-Reliance." ${ }^{\text {"07 }}$ Ralph Emerson's doctrine of self-reliance and individualism is indeed a clear reflection of Wright's career. Emerson's radical conception of selfhood that called for liberation not only from religious doctrine, but also from established tradition and hierarchy, is also an epigram of the contemporary architectural practice and its retreat to an autonomous and disinterested realm.

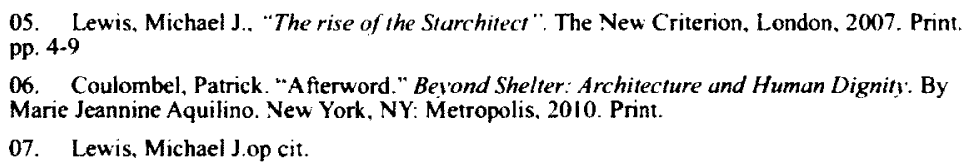

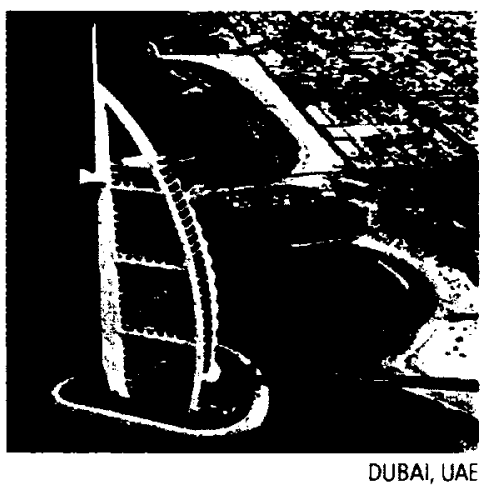

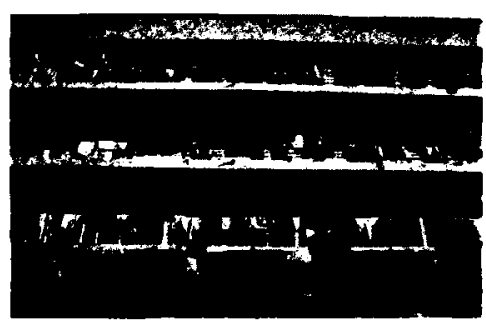

SONAPUR LABOUR CAMP, DUBAI -Matilde Gattoni

Architecture has been used as a symbol of power and economic excess in Dubai. However, the star-architect designed buildings are built by the hands of millions of migrant workers that work 14 hour days in the desert heat and live in labour camps such as Sonapur, where over 300,000 men pile up in a rubble-strewn patchwork of identical concrete buildings. Most of these construction workers can't leave Dubai because they were initially conned into coming to the country with promises of high salaries and good living conditions. They took up debt with their employers and loansharks they can't payoff, and their passports are taken upon arrival by the construction companies.

$h t t p: / / w w w$ independent.co.uk/opinion/commentators/ johann-hari/the-dark-side-of-dubai-1664368.htm! 
According to Jeremy Till, the autonomy of architecture allows architects to detach themselves as humans (social, political, and ethical beings) and then look through the wrong end of the telescope, and so to see the world as an abstraction. "One might think that an abstracted world can be ordered, beautified and perfected, but in the end the real world will come back to bite you. Any permanent detachment is deluded. Purity is a myth." ${ }^{08}$ Till argues that architecture is defined by contingency, yet, the profession and practice does everything to resist and deny the dependency of their discipline. "Architects", Till claims, "feel more comfortable in a world of certain predictions, in a linear method, in the pursuit of perfection." ${ }^{09}$ This 'pursuit of perfection' was epitomized during modernism, when cleanliness was appropriated and beauty was associated with pure forms, elimination of decoration, and white walls. This cleanliness was often associated with a moral order made possible by the actions of the architect. ${ }^{10}$ As Le Corbusier described: "we would perform a moral act: to love purity... whitewash is extremely moral."

If visual purity is a direct association to social morality, does this mean that the supposed immoral, such as squatters and slum dwellers, should be cast aside because of their threat to order and formal perfection? In agreement with Le Corbusier, in Civilization and Its Discontents, Sigmund Freud identifies beauty, cleanliness, and order as occupying "a special position among the requirements of civilization" 11 - does this mean that the dirty and the disordered fail to merit an accepted position among the rest of civilization?

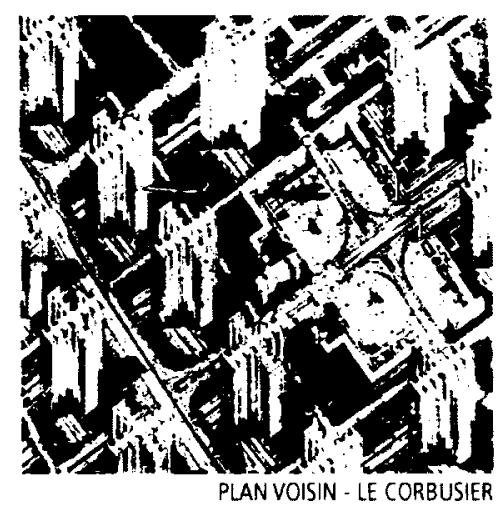

Plan Voisin, an unrealised project by Le Corbusier meant to house three million inhabitants in a development that would abloish the human street and destroy the social elements of a city that produce change in time. This dystopia became reality in various ways. The Plan's building type has shaped public and social housing around the World in housing estates for the poor that resemble warehouses.
08. Till. Jeremy. Architecture Depends. Cambridge. MA: MIT, 2009. Print.

09. Till, Jeremy, lbid.

10. Ibid. (Till)

11. Freud. Sigmund. Civilization and lts Discontents. New York: W.W. Norton, 1962. Print. 
Lebbeus Woods argues that even though the elevation of the architect to a role of an autonomous creator may have been innocent and admirable during Modernism, it is no longer so in contemporary architecture practice. "Aware of the history of the past hundred years and the turbulent character of the present, such an attitude can only seem arrogant and self-indulgent." Woods argues that many present day architects, including many whose buildings will go down in architectural history as masterpieces, are "utterly oblivious to the uncertain and conflicted human condition of today which is unprecedented in history." Woods continues in his argument to suggest that what is urgently needed now is the very antithesis of utopian purity, what he defines as 'Masterpieces of Imperfection'. ${ }^{12}$

\section{MASTERPIECES OF IMPERFECTION}

Is it possible that these 'Masterpieces of Imperfection' already exist in the form of slums and squatter settlements? Slums exemplify many of the textbook qualities that make up strong urban environments: low-rise, high-density, mixed use. They are home to well-functioning public spaces, heterogeneous communities and aesthetically complex and interesting spaces created by a layered palimpsest of an informally built urban morphology.

In an age where sustainability is the keyword, slums are "green" in their efficient use and reuse of materials for construction and livelihood activities. They are highly walkable, often represent optimal utilization of space and are easily adaptable to changing user needs. Despite the common misperception of slums being unsafe, slums actually promote safety by channeling "eyes on the street." ${ }^{13}$

\footnotetext{
12. "Zaha's way" Lebbeus Woods. Web. 06 Feb. 2012. <http:/1ebbeuswoods.wordpress. com/2011/03/27/zahas-way/>.

13. "Slumchitecture." Where. Web. 18 Jan. 2012. <http:/thewhereblog.blogspot.com $/ 2009 / 04$ slumchitecture.html>
}

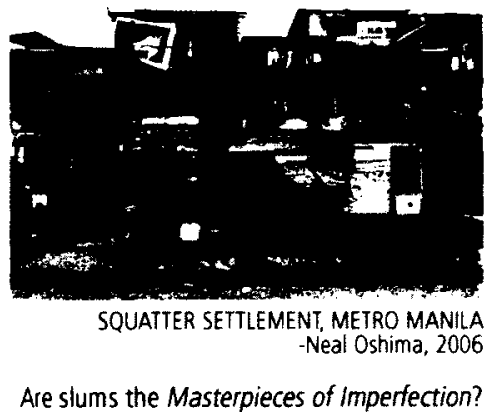


Perhaps slums can be considered as the new utopian landscapes - and they couldn't be more different than the neat segmentation and uniformity of the previous generation's suburban and modernist dreams. ${ }^{14}$ Upon returning from a trip to Dharavi, Prince Charles described his experience in the following manner: "it may be the case that in a few years' times such communities [as Dharavi] will be perceived as best equipped to face the challenges that confront us because they have a built-in resilience and genuinely durable ways of living." The Prince noted that the district's use of local materials, its walkable neighbourhoods, and mix of employment and housing add up to "an underlying intuitive grammar of design that is totally absent from the faceless slab blocks that are still being built around the world to 'warehouse' the poor". ${ }^{15}$ He concluded by warning that a soaring urban population - rising from $50 \%$ of the entire world's inhabitants today to $70 \%$ by 2050 - could only be accommodated without disastrous social and environmental consequences by developing local urban design rather than "a single monoculture of globalisation" - the primary answer that the architectural field has provided since modernism.

Slums are far from perfect; the scent of a slum isn't sterile, the walls aren't very white. There is dirt on the street and sewage runs through the alleyways. There is no grid to organize, control and categorize the slum occupants, and the buildings are contingent and never quite finished. Yet they are often cleaned with utmost pride. Slums are resilient and independent. Furthermore, slums enable a sense of community that modernist architects disregarded and contemporary architects are perhaps too preoccupied with formal exercises to engage. Therefore, as architects, it is time - as Teddy Cruz aptly described - "to put Marcel Duchamp's urinal back on the wall". ${ }^{16}$

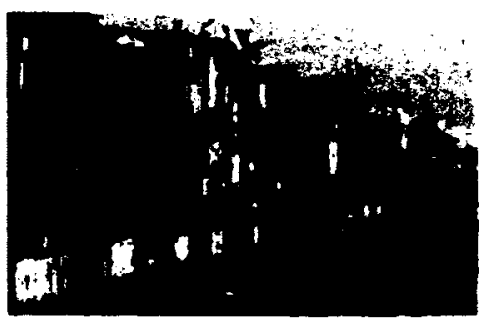

DHARAVI SLUM, MUMBAI -Scott Eells

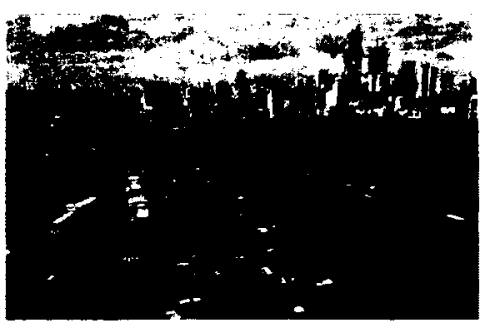

DHARAVI SLUM, MUMBAI -Scott Eells

14. "Slumchitecture." ibid

15. Booth, Robert. "Charles Declares Mumbai Shanty Town Model for the World : The Guardian." The Guardian. Chttp:/Www.guardian.co.uk/artanddesign/2009/feb/06/princecharles-slum-comments".

16. "MAS Context." Urban Think Tank Mas Context. Web. (44 Apr. 2012. <hrtp:/www. 
Despite their resilience and the 'success' many slums have had as not only surviving, but thriving as communities, they are still plagued with deep social and sustainability concerns that have been described in the previous chapter. This is where, in the global south, we will suggest that the architect has the opportunity to engage in the role of an 'agent of change' As Jeremy Till puts it, "We need more people who dare to eschew the greats and the specials, and look to the everyday, the social, and the economic as forces that shape architecture." 17

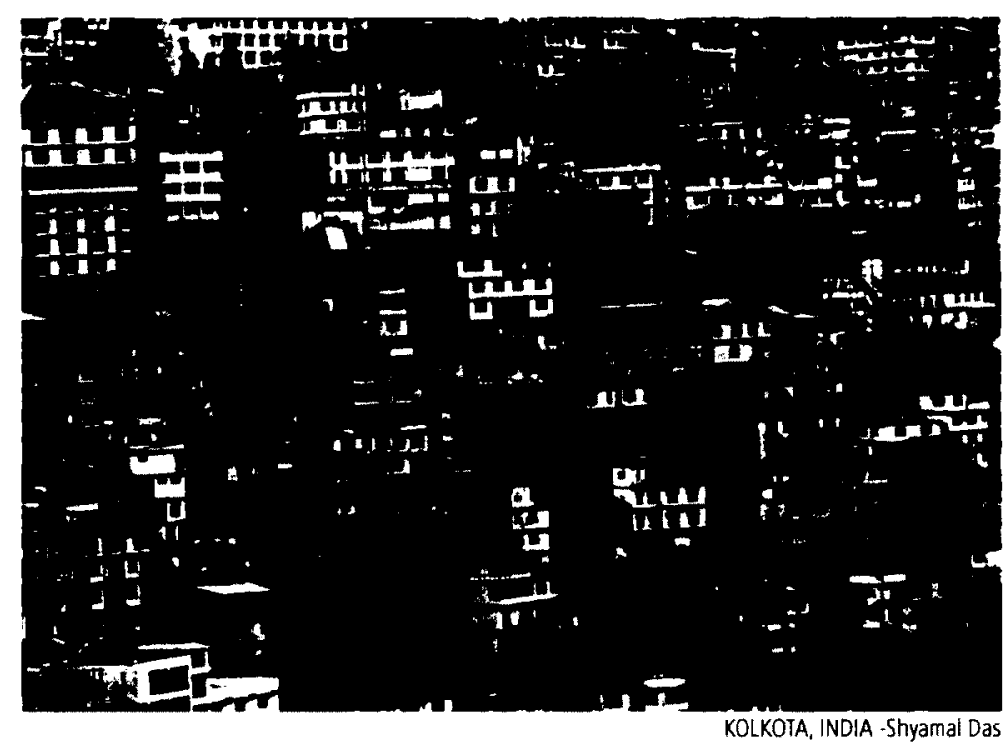




\section{SQUATTER AGENCY}

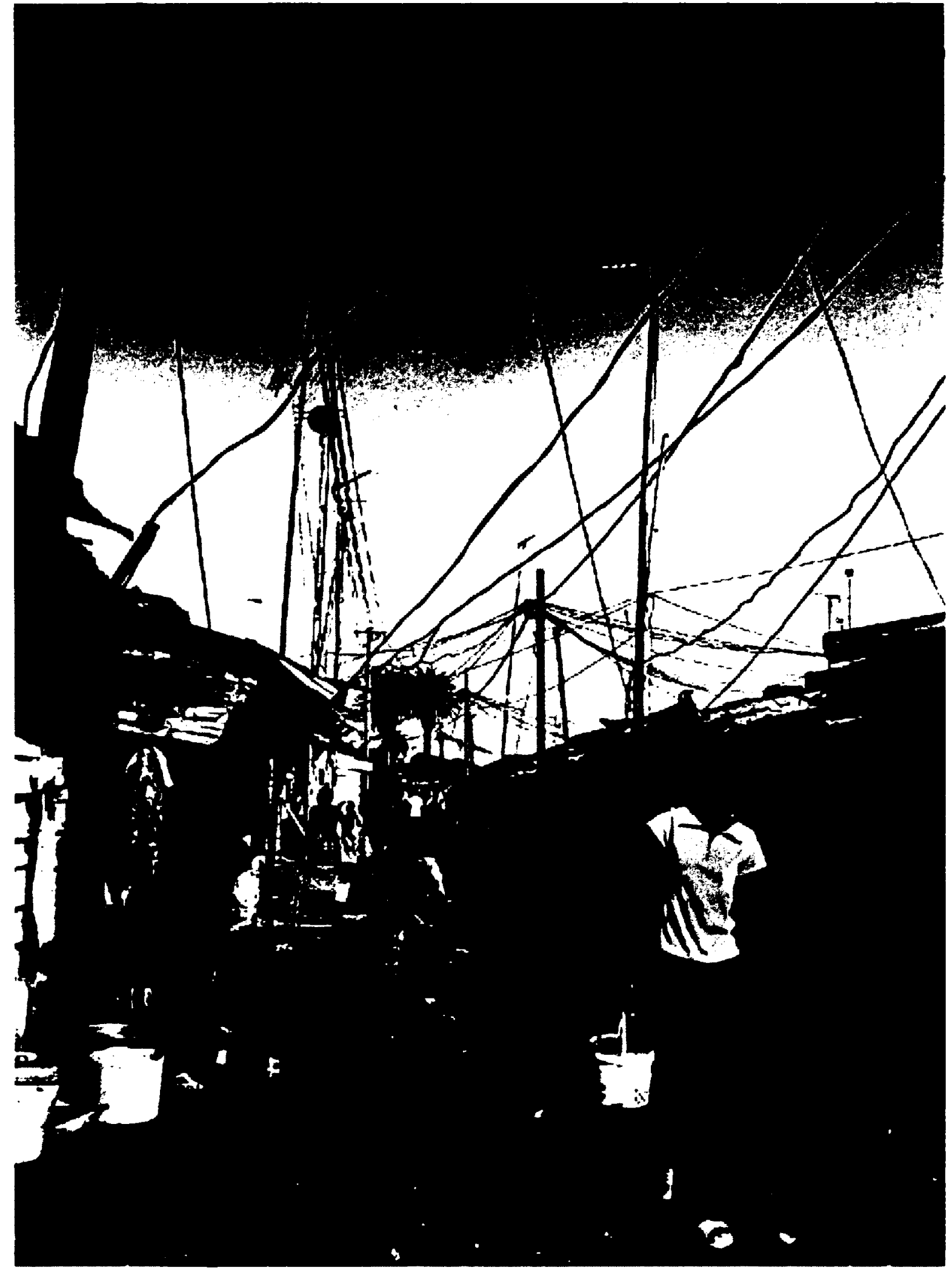




\section{SQUATTER AGENCY}

"Architecture performs as an edification mechanism which empowers citizens: allows communities to have a sense of cohesion and allows disparate parts of communities to find some sense of direction within the idea of a city." A

-David Adjaye

The preceding chapters proposed that the future of developing cities and, therefore, the future of humanity - depends to a large extent on decisions that are taken now with respect to the organization of upcoming city growth. ${ }^{01}$ With regards to slums, it is clear that existing approaches taken by governments are generally ineffective and unsustainable. Slum removal simply relocates the problem at a high human cost, postponing the day when it must be dealt with more humanely, and on a more enduring basis. On the other hand, forceful 'urban renewal' approaches - where slums are demolished and transformed into large-scale housing projects - have also generally failed. ${ }^{02}$ A slum, however misunderstood, has social structures and human value that cannot be replaced by public housing projects that treat developed settlements as a tabula rasa.

Intervention that is imposed by external forces rarely results in an adequate or positive solution to a problem. Many third-world countries that are now confronted with an unsustainable slum growth were at one point subjugated to external colonisers. In fact, The British were arguably the greatest slum-builders of all time. In India, Burma and Ceylon, their refusal to improve sanitation or provide minimal infrastructure to native neighbourhoods ensured homelessness and huge death tolls from epidemics such as plague, cholera and influenza. ${ }^{03}$

A. Burdett, Richard, and Deyan Sudjic. The Endless City: The Urban Age Project by the London School of Economics and Deutsche Bank's Alfred Herthausen Society. London: Phaidon, 2007. 484-87. Print

01. Martine, George. Op Cit., p. 2

02. "SLUMS: What to Do?" Lebbeus Woods. Web. 16 Feb. 2012. <http://lebbeuswoods. wordpress.com $/ 2008 / 01 / 28 /$ slums-what-to-do $>$.

03. Davis, Mike, Op cit., p. 52

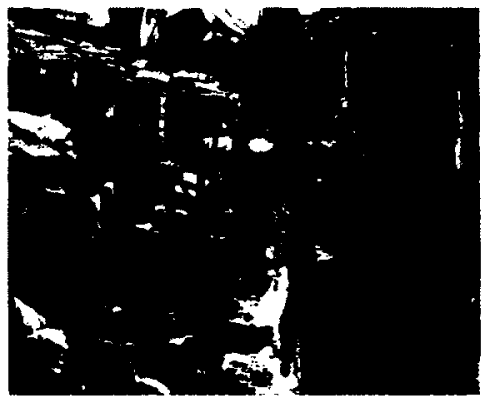

STREETS OF DHARAVI, INDIA - Jonas Bendiksen 
Likewise, in order to affirm their dominance over the indigenous people, Spanish colonisers raised their new capital on the ruins of Tenochitlan (modern day Mexico City). Tenochitlan was an amphibious city, built on a lake with complex hydraulic systems that maintained safe water levels to avoid floods, communicated the region through canals, and supplied clean water throughout the city. ${ }^{04}$ The Spanish colonisers viewed the lake as a nuisance instead of an asset and opted to drain the lakes so that they could distribute and occupy the land. ${ }^{55}$ The consequences of their actions are suffered to this day by low-income settlers of Mexico City that are paradoxically affected by perennial floods and the lack of potable water in the region.

In general, the postcolonial state has comprehensively betrayed its original promise to the urban poor. The neoliberal, top-down approaches to slum elimination and improvement have failed to produce a viable solution to this pressing issue, and likewise, architecture has yet to play a significant role in slum improvement. So how can architecture enable positive change within informal settlements without falling into the mistakes of the past? Perhaps the solution isn't found outside of the slum at all. Perhaps the solution lies within the slum, with the slum-dwellers that have resiliently managed to survive and, in many cases, thrive despite their adverse situation.

Lebbeus Woods believes the solution can be found through architectural interventions (which he conceives as capsules) that are aimed at empowering slum dwellers to find or invent the ways to transform their own conditions. "After all", proposes Woods, "they (the slum dwellers) understand these conditions better than anyone, where they work
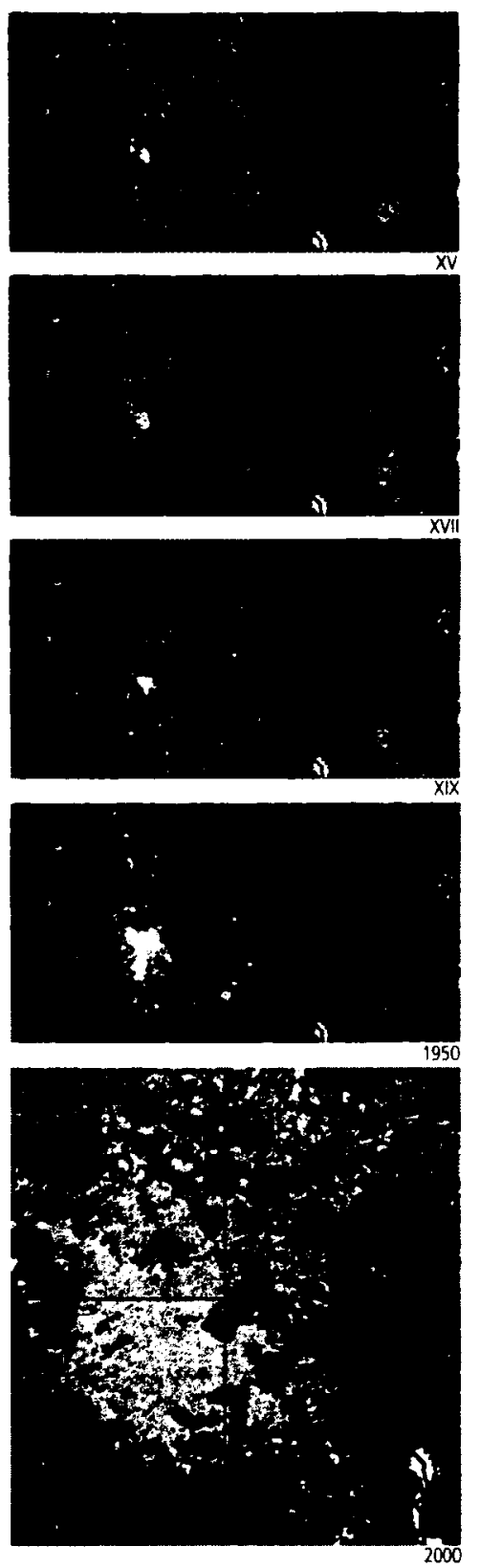

MEXICO CITY URBAN GROWTH OVER TIME - A. Kalach

04. Kalach, Alberto, and Lipkau. Gustavo, México: Ciudad Futura. Barcelona: RM Verlag 2010. Print. P.48.

05. Kalach \& Lipkau, /bid., P.67. 
for them and where they do not. If the slum dwellers have admirable ingenuity in surviving under the most terrible of conditions, why should this same ingenuity not be the key to transforming slums and eventually eliminating them?"06

According to Woods, the biggest task is to address the problem of changing the terrible physical conditions of slums. Such a task will require new ideas about how to effect changes in conditions from within. ${ }^{07}$ Woods warns that the interventions might seem like an unwelcome intrusion from outside, just another hasty remedy imposed by the economically advantaged on the poor. Because of this, it is especially important that the interventions enable slum-dwellers to achieve their goals, serving their values, and do not reduce them to the subjects of their designers' will. "Inevitably, the values, prejudices, perspectives and aspirations of the designers and makers will be imbedded in the capsule and what it does. Therefore the slum-dwellers should, in the first place, have the right to refusal. Also, they must have the right to modify the capsule and its effects as they see fit... The implication of these freedoms is that the capsule, whatever its capabilities, could be used to work against the intentions of its designers and makers." ${ }^{08}$

This type of grassroots approach - where change is initiated from within the slum, and where the contingency of a project is embraced instead of being rejected - detaches the architect from the traditional figure of 'individual hero' and instead, attempts a more collaborative approach, where the architect acts with, and on behalf of, the slum dwellers.

Architecture is rarely delivered through a single individual; but, as Tatjana

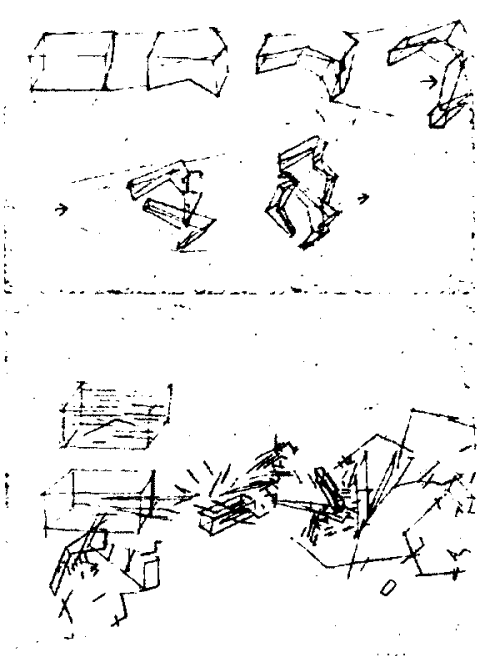

SLUM INTERVENTION CAPSULES - L.Woods

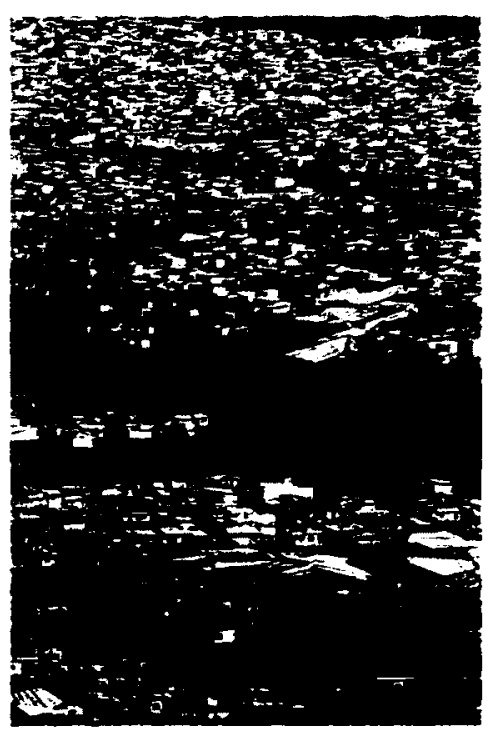

SLUM INTERVENTION CAPSULES - L.WOods

\footnotetext{
06. Woods, "SLUMS: What to Do?" Op Cit.

07. Woods, "SLUMS: What to Do? Ibid.

08. Ibid. (Woods)
} 
Schneider and Jeremy Till expressed in a 2009 article in Footprint journal regarding agency in architecture ${ }^{09}$, the mythology of the sole architect as hero-author is played out through the figures of prominent architects that disguise the reality of how little of the built environment is associated with any architect-author whatsoever. This new role of architectural agency is where the architect acts instead as anti-hero: someone who coauthors from the beginning, someone who actively and knowingly gives up authority, someone who doesn't work in the foreground, but instead takes a step back and someone who is part of the process, but not always the initiator of the project. ${ }^{10}$

Agency is intractably tied to power, as the Oxford English Dictionary defines it as: 'one who exerts power or produces an effect.' Therefore, the agent - which can be both architects and their buildings - is one who effects change through the empowerment of others. Empowerment happens when others 'take control' over their environment. ${ }^{11}$ According to Schneider, empowerment is not about the transfer of decision-making power from 'influential' sectors to those previously disadvantaged or 'other' sections of society, but about these 'others' taking control and initiating different or 'alternative' spatial processes including, but not restricted to, the making of buildings.

So much architectural social production has been solely focused on the design and delivery of social buildings that are commissioned by sectors of influence. The intent of 'Squatter Agency' is to open up a more dynamic continuity that exceeds, without excluding, the design of buildings. Agency within a squatter settlement is about empowering its residents to take control over their community that so often falls victim to external forces that attempt to regulate the conditions of a slum. Such regulation,

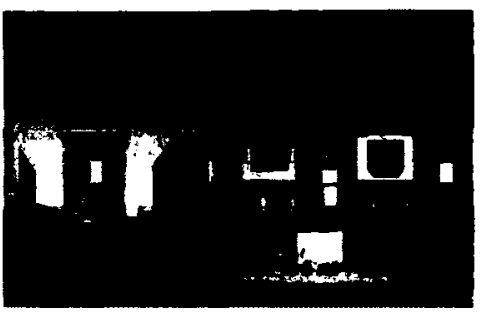

IQUIQUE HOUSING PROJECT BY ELEMENTAL

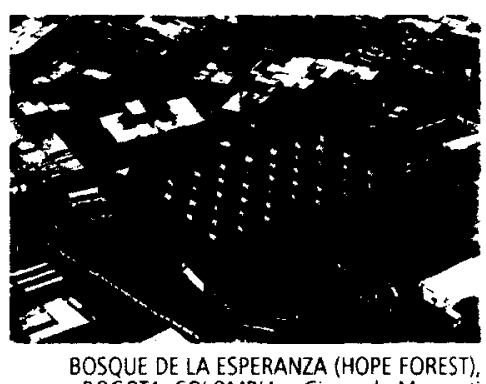
BOSQUE DE LA ESPERANZA (HOPE FOREST),
BOGOTA, COLOMBIA - Giancarlo Mazzanti

09. Schneider, Tatjana, and Jeremy Till. "Beyond Discourse: Notes on Spatial Agency."FOOTPRINT 4 (2009): 97-112. Print

10. Ibid. (Schneider \& Till)

11. Ibid. (Schneider \& Till) 
though often well intentioned, can destroy the bottom-up community organization and independence that slum-dwellers had achieved within their informality. Squatter agency should not seek to exclude exterior forces from acting within an informal settlement; proper infrastructure, sturdy structures, reliable services and social inclusion are all important benefits that are a consequence of external intervention. Squatter agency instead should propose alternative, participatory approaches that involve both interests and where, as Anthony Giddens formulates, there is the capability of 'acting otherwise'. 12

Urban space provides the opportunity for democratic engagement. When the city operates as an open system it becomes democratic, not in a legal sense, but as a physical experience. Democracy is no longer an issue of formal governance but instead, a focus of citizenship and participatory issues that can be influenced by the physical city and its design. According to the sociology professor Richard Sennett, "The slums that abound in most developing country cities are evidence of a lack of urban democracy. Even when there is abundant land suitable for urbanization, the poor are forced to locate on steep slopes prone to landslides and other risks, or on low lands that are often flooded. Though over time poor neighborhood may solve the worst flooding risks and end up getting water supplies, and other basic necessities, they are never cured of their lack of public space." ${ }^{13}$ So how can design influence this democratic engagement? How and where can architecture introduce urban democracy into an informal settlement?

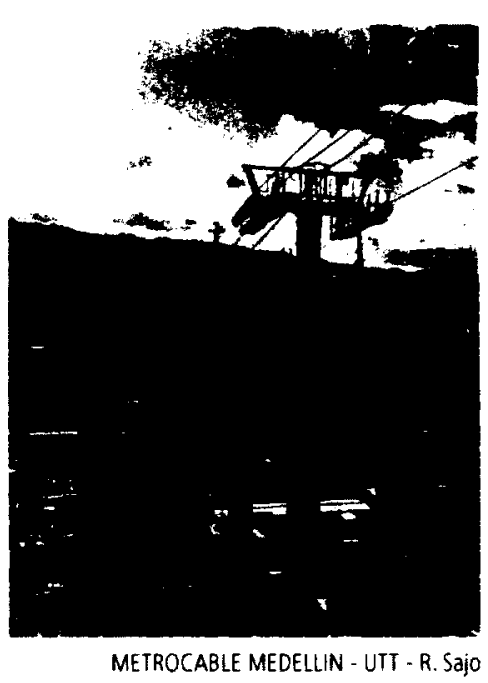

METROCABLE MEDELLIN - UTT - R. Sajo

12. Giddens, Anthony, Social Theory and Wodern Siciologi: p. 216.

13. Sennet, Richard, The Endless Cin: The Urban Age Project by the London School of Economics and Deutsche Bank's Alfred Herrhausen Societn: By Richard Burdett and Deyan Sudjic. London: Phaidon. 2007. Print. P.296. 
The places where architects can exert influence within a slum are manifold. The conflicts that exist between the formal and the informal worlds can seem like daunting challenges, but they can also be seen a place where opportunities for new hybrid models can emerge. Buckminster Fuller proposed that to change something, we must build a new model that makes the existing model obsolete. These new models, or 'capsules' as Lebbeus Woods proposed, can be the product of an ongoing negotiation between the conflicting positions of the formal and the informal - wealth vs. poverty, top-down approaches vs. bottom-up approaches, competitive vs. cooperative, private vs. communal, urban vs. peri-urban, etc. Hence, the architect can act as a mediator of these conflicting positions and, through his interpretation, provide alternatives that satisfy formal requirements, while empowering informal settlers to democratically define their own communities.

One method of empowerment is through knowledge. This is what the following project - the parachutists' alternative - is based upon. The intention of this pamphlet isn't to provide a comprehensive study of proper methods of slum improvement or intervention, but instead, an introductory guide to alternative processes of spatial production within a specific setting.

When squatters arrive to a city, they are usually confronted with the daunting task of adapting to an unreceptive territory with little knowledge of city life. They are very much dependent on the acts of government and rarely have much influence over the seemingly standardized regularization process that is imposed through top-down urbanization procedures.

Providing squatters with knowledge of alternative solutions of spatial production is a type of agency that will better empower squatters to negotiate their development. Information and knowledge are often taken

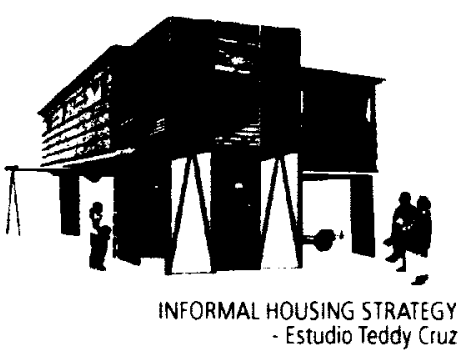


for granted by affluent sectors of society and professional fields since it is so easily accessible and obtainable. For squatters on the other hand, information can be a luxury: it is not easily obtainable and it is often used against them. By providing squatters with alternative information and examples of how to build their community, they can be better empowered to provide their own spaces, and to leverage their political clout to transform their communities.

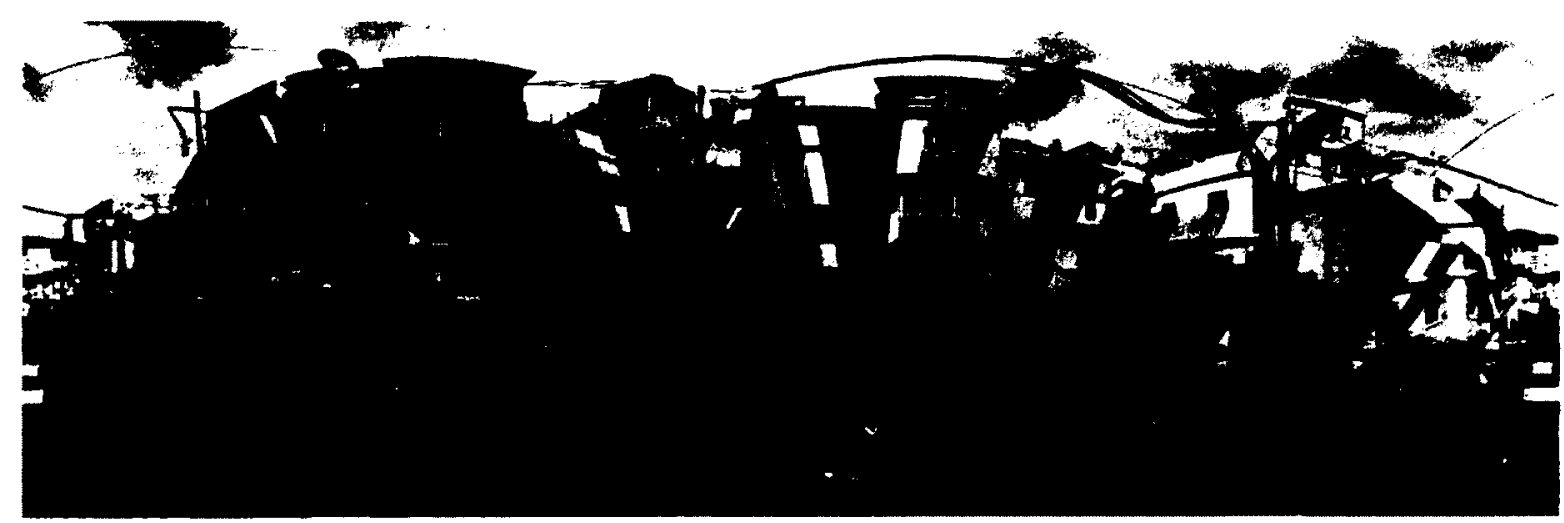

FAVELA PAINTING IN SANTA MARIA, RIO DE JANEIRO - Jeroen Koolhaas and Dre Urhahn 


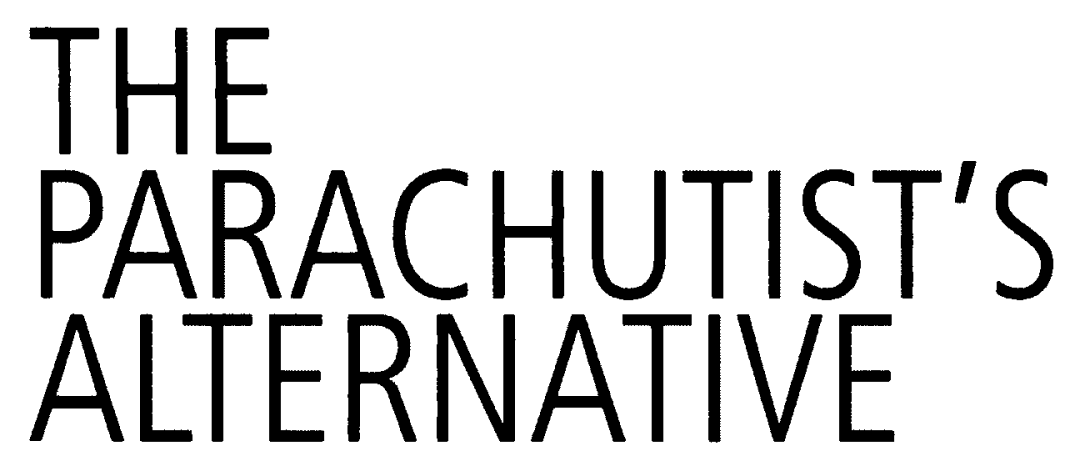

ALTERNATIVE SOLUTIONS TO EFFECTIVE INTERVENTION IN THE CHIMALHUACAN SQUATTER SETTLEMENT
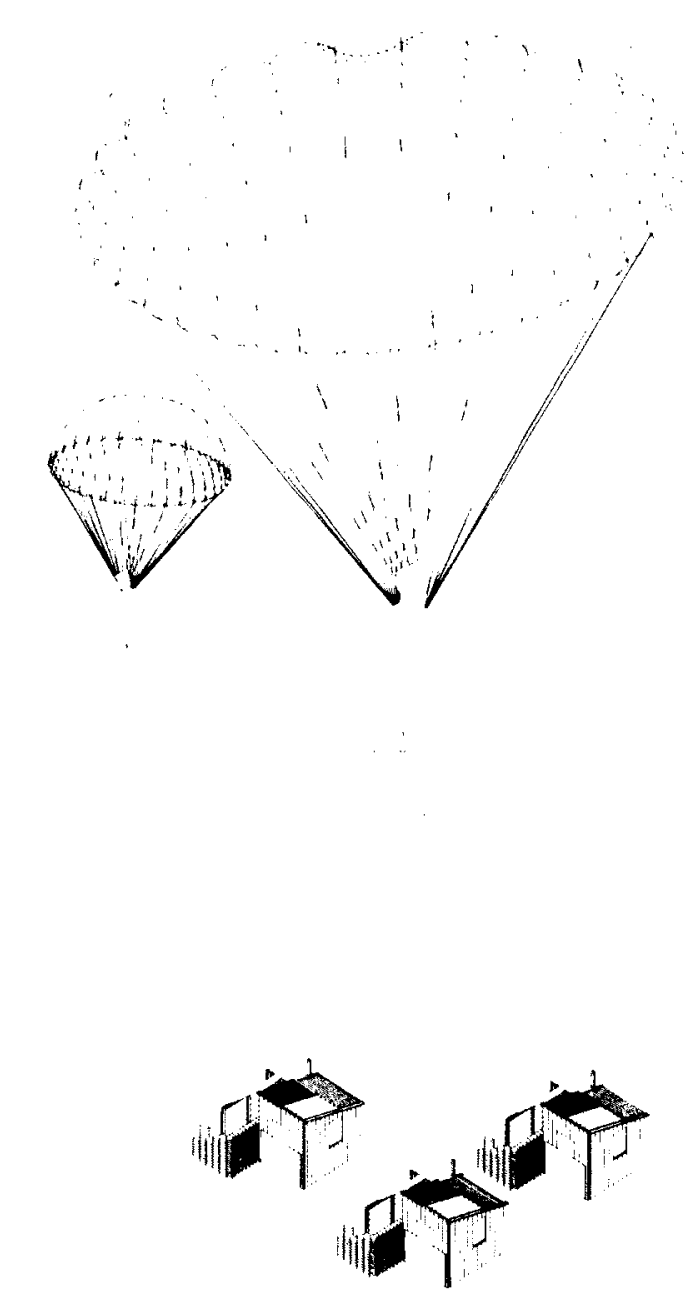

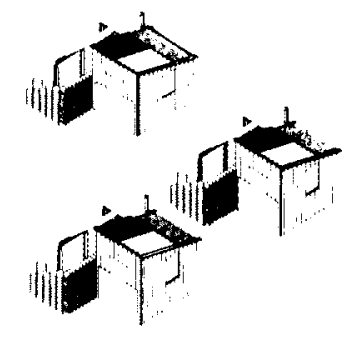


The Parachutist's Alternative is intended to serve as a practical guide to alternative methods of spatial intervention within Mexico City's informal settlements. This pamphlet is written for parachutists, activists, and informal community organizers that proactively seek to improve the architectural context of their settlement, or who reactively seek to protect their settlements from intrusive processes of governmental regularization by proposing less invasive and more favourable alternatives to their social, spatial and environmental problems.

Parachutists (from the Spanish term 'Paracaidista') will be understood as those who descended onto the city and out of need took-over unused and/or undesirable land for their personal use in order to forge a home for their families and their communities. It is also understood that the Parachutists may not be first generation parachutists since the process of Mexico City's urbanisation began decades ago, but instead, may be a descending generation of parachutists that appreciate the sacrifice and resilience of the preceding generation, and now seek to improve and consolidate their settlements.

The intention of this pamphlet isn't to act as a guide of how architecture should be built in an informal settlement, rather, it is an alternative example of how architecture could be built and appropriated by the parachutists.
The purpose of this project is to provide inspiration for further grassroots projects that come out of the informal settlement that can be viable alternatives to government- and developer-driven processes of regularization.

Each informal settlement has its own unique characteristics and problems. The Parachutists Alternative seeks to address the specific situation of the Chimalhuacán municipality in eastern Mexico City. The pamphlet will provide basic speculative examples of alternative approaches that deal with housing, waste-management, and community involvement spaces. Though the information in this pamphlet is intended for Chimalhuacán, the approaches can be adapted and repeated in other irregular settlements in and around Mexico City. 


\section{PROJECT CONTEXT}

Mexico City is a sprawling and fragmented megalopolis with a metropolitan population of over 20 million people ${ }^{01}$. The city is currently confronted with the challenge of integrating its mosaic of segregated settlements to the existing urban network, while at the same time controlling its ever-expanding urban sprawl. ${ }^{02}$

Colonial land use and topography have historically segregated Mexico City; higher social classes settled in the higher areas to the West and South of the city that are relatively safe from flooding and have enjoyed more immediate access to water supplies, while lower classes have settled on the saline flat lands to the East that are more prone to flooding when it rains, and dust storms in the dry season. ${ }^{03}$ Intensive industrialization and concurrent urbanization after 1940 further segregated the population with the creation of peripherally located asentamientos irregulares or colonias populares - irregular or 'popular' settlements comprised of self-built and mainly owner-occupied dwellings - that emerged as the leading housing option for lower income families. ${ }^{04}$ The urban researcher Priscilla Connolly explains that

O1. "Censo De Poblacion Y Vivienda 2010.Resultados Preliminares." Censo De Poblacion Y Vinienda 2010. Resultudos Preliminures. Web. 04 Mar. 2012. <http:/www.inegi. org.mx/sistemas/TabuladosBasicos/

02. "Mexico City: Growth at the Limit?"' Urban Age. Web. 04 Mar. 2012. Chttp://urban-age.net/03 conferences/conf_mexico(ity.htmls.

03. Connolly, Priscilla. Urban Slums Report: The Case of Mexico City: Mexico. Rep. London: Development Planning Unit, University College London, 2003. Print. P.4 04. Connolly. Priscilla. "Understanding Slums: Case Studies for the Global Report 2003." UN Habitat. Web.
04 Mar. 2012. <htip:/www.uclac.uk/dpu-projects/Global_Repor/cities'mexico.htm>.

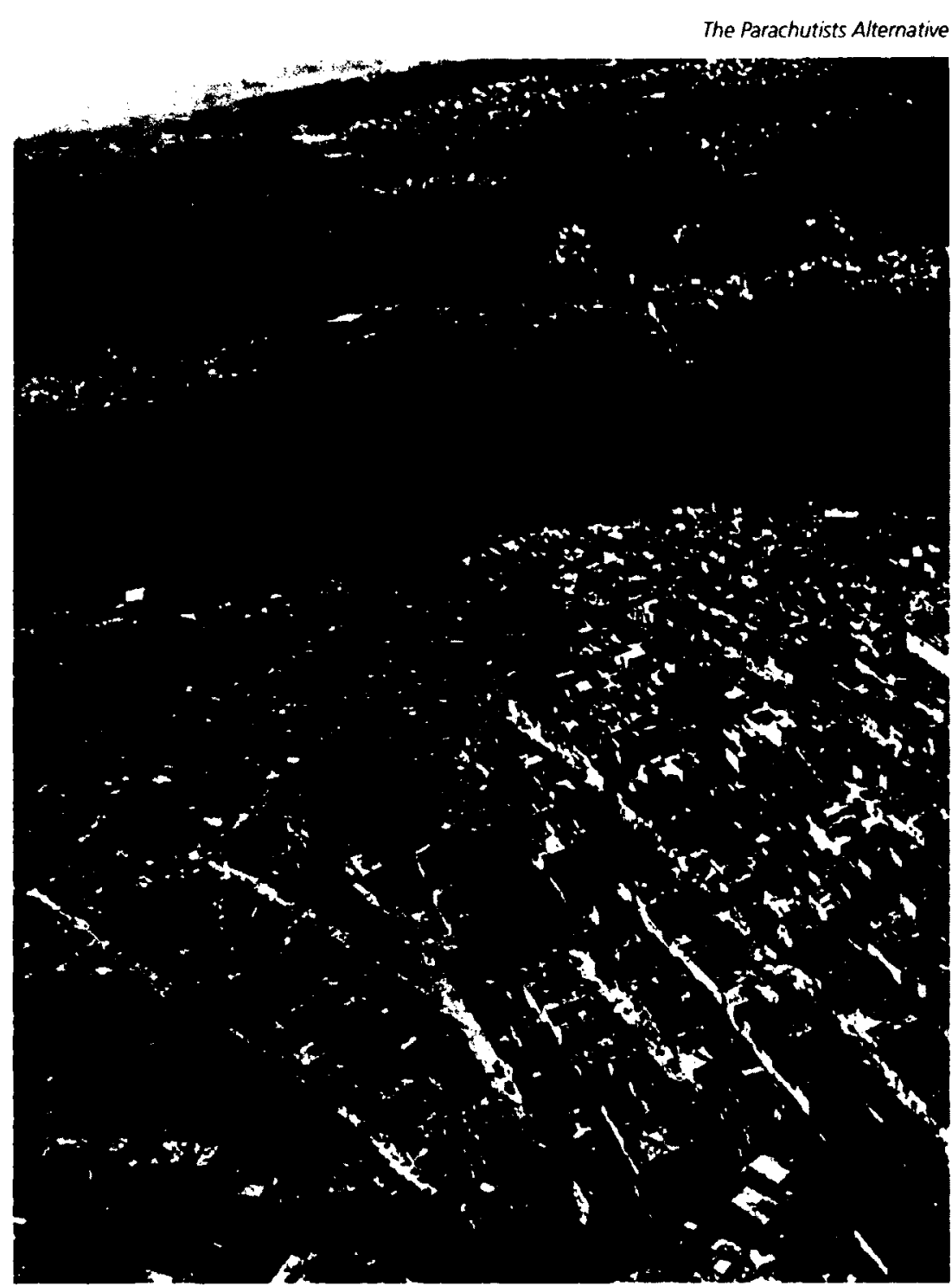

MEXICO CITY URBAN SPRAWL - PABLO LOPEZ LUZ 
popular denotes "not well to do" though not necessarily "poor" or "extremely poor" and "irregular" means that they were not legally developed. "The causes of their illegality, however, have included a variety of closely interlinked conditions: unauthorised land development, non-fulfilment and inexistence of building permits, initial and sometimes permanent lack of urban services, high risk of flooding and other hazards, and in this case (Mexico City), agrarian communal property law, with all its ambiguities and contradictions." ${ }^{\text {05 }}$ Connolly notes that most of these settlements have been regularised to a varying degree - as land titles were devised and distributed, infrastructure and services put in, improvements to housing, and mixed uses installed. Nevertheless, except in the very few cases where blanket gentrification has occurred, colonias populares never become completely regular. ${ }^{06}$ Most of these settlements were established irregularly on drained lakebeds and the steep hillsides surrounding Mexico City's extinct lakes which are undesirable for most conventional building uses, and hence, provide a cheap alternative for unauthorised settlement. Some of these hills have been mined for building materials, adding subsoil collapse to the existing hazard of high gradients and permanent lack of services. ${ }^{07}$

05. Priscilla Connolly. Op.cit., p. 12
06. Ibid. (Connolly)

07. Priscilla Connolly. Op.cit., p.5.

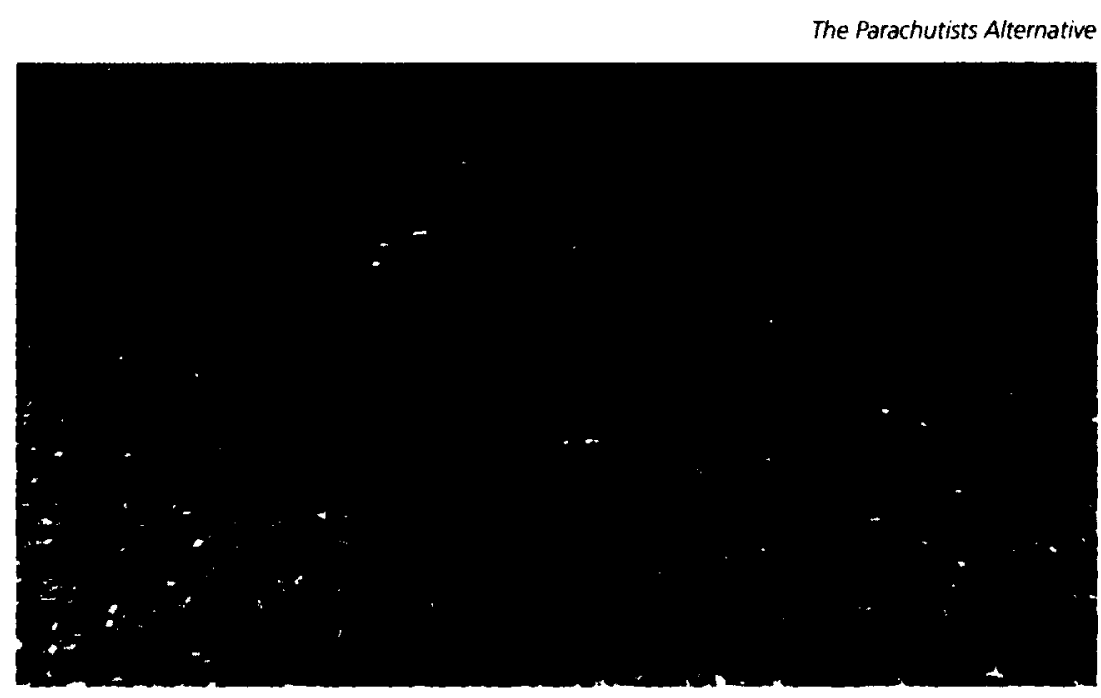

CIUDAD NEZAHUALCOYOTL, MEXICO CITY

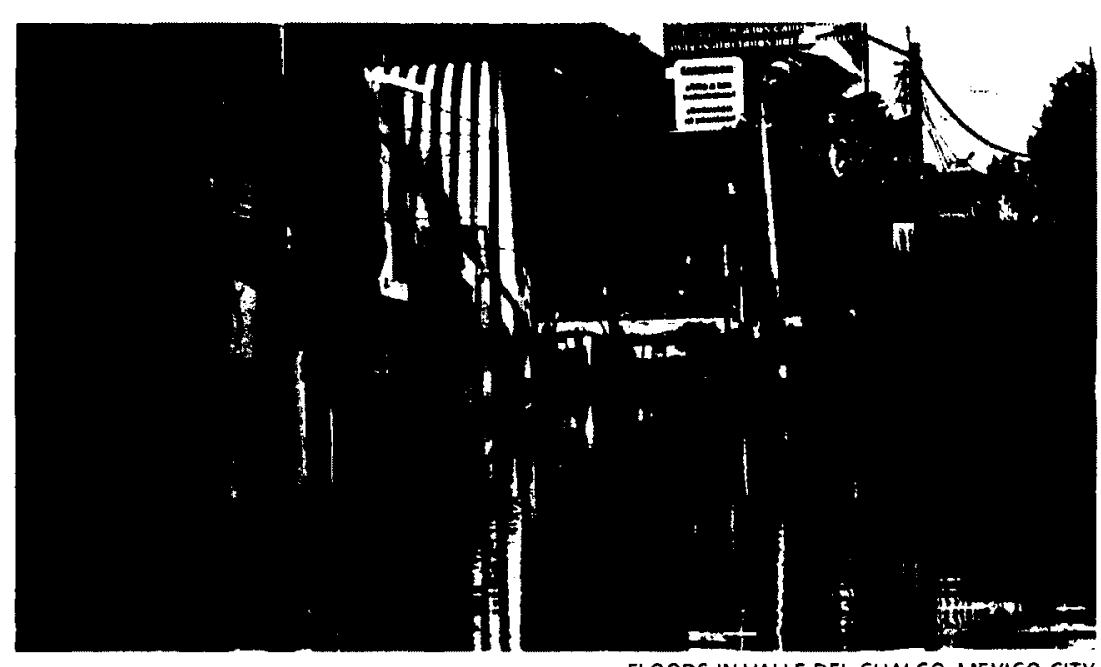

FLOODS IN VALLE DEL CHALCO, MEXICO CITY

PAGE 45 
Today, over $60 \%$ of the total population in the Mexico City metropolitan area live in such "popular" settlements. ${ }^{08}$ However, it is important to point out that not all of these residents should be considered 'slum-dwellers', in fact most colonias contain a degree of social heterogeneity despite being mainly inhabited by lower-income segments of the population. ${ }^{09}$

The concept of marginality has evolved throughout Mexico City's urban influx. Irregular settlements that were established decades ago on the city's edge are no longer on the periphery and have undergone a process of consolidation. Most of these settlements are now experiencing a densification process, mainly through additions to existing housing units that are usually self-built and implemented without technical guidance or regards to healthy design principles such as privacy, ventilation and lighting. ${ }^{10}$ On the other hand, a large amount of low-income residents of Mexico City's centre are being forced out because of rising prices and are settling in massive subdivisions of low quality affordable housing that is being built by both formal and informal developers in peripheral areas. "The concentration

08. "Mexico City: Growth at the Limit?" Op cit.

09. Connolly. Priscilla. Op cit. p.6

10. "Mexico City: Growth at the Limit?" Urhun Age. Web. 04 Mar. 2012. Chttp:/urban-age.net/03 conferences/conf_mexicoC'ity.homls.

11. "Mexico City: Growth at the Limit?"Op cit.

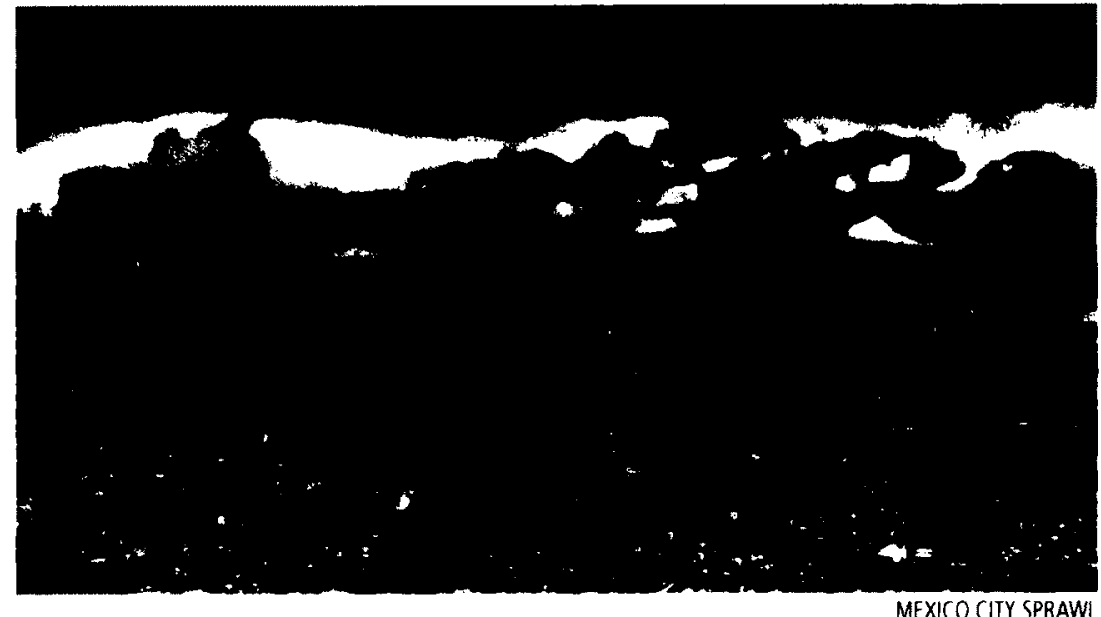

MEXICO CITY STATISTICS

- Average Daily Commute in Mexico City: 2h 30 min.

- $55 \%$ of journeys are made by minibus or collective taxis.

- $76 \%$ of Mexico's population live in Urban Areas.

- $200 \mathrm{~km}$ of Underground metro compared to $408 \mathrm{~km}$ in London.

- Federal District: 1,484km2, Metropolitan Zone: 4,979km2.

- $22 \%$ of Mexico's GDP is contributed to Mexico City.

- $7.5 \%$ of Land used for recreation in the Metropolitan Zone.

- $60 \%$ of Construction is done by the informal sector.

The Endless Ciry: The Urban Age Project by the tondon School of Economics and Deutsche Bank's Affred Herchausen Socient By Richard Burdett and Deyan Sudjic London: Phaidon, 2007 . Print 
of affordable housing units and their isolation from other uses and public spaces accentuate the city's fragmented urban structure and social segregation.

According to Wolfgang Nowak, Mexico City epitomizes the tensions between spatial and social order. "The city's endless low-rise spread, with 60 per cent of its over 20 million inhabitants living in illegal and informal housing, conceals a fastdeveloping landscape of difference exacerbated by the dominance of the car in a city where petrol is cheaper than mineral water". Nowak argues that investment in two-tier motorways instead of public transportation is pulling the city further apart, lengthening commuting times for its workers and pushing the poor to the far fringes of the seemingly limitless city. Nowak summarizes the Mexico City's social segregation in the following way: "In Mexico City, the rich seek protection in golf-course residential typologies within armed and gated communities or in the emerging vertical ghettos of Santa Fe that overlook the organic but wellestablished Shanty-towns, where a vibrant informal sector constitutes 60 per cent of the city's economy." 12

According to Geetam Tiwari, much of this economy is hidden - "an unofficial system of squatter landlords and squatter tenants, squatter merchants and squatter consumers, squatter builders and squatter labourers, squatter investors

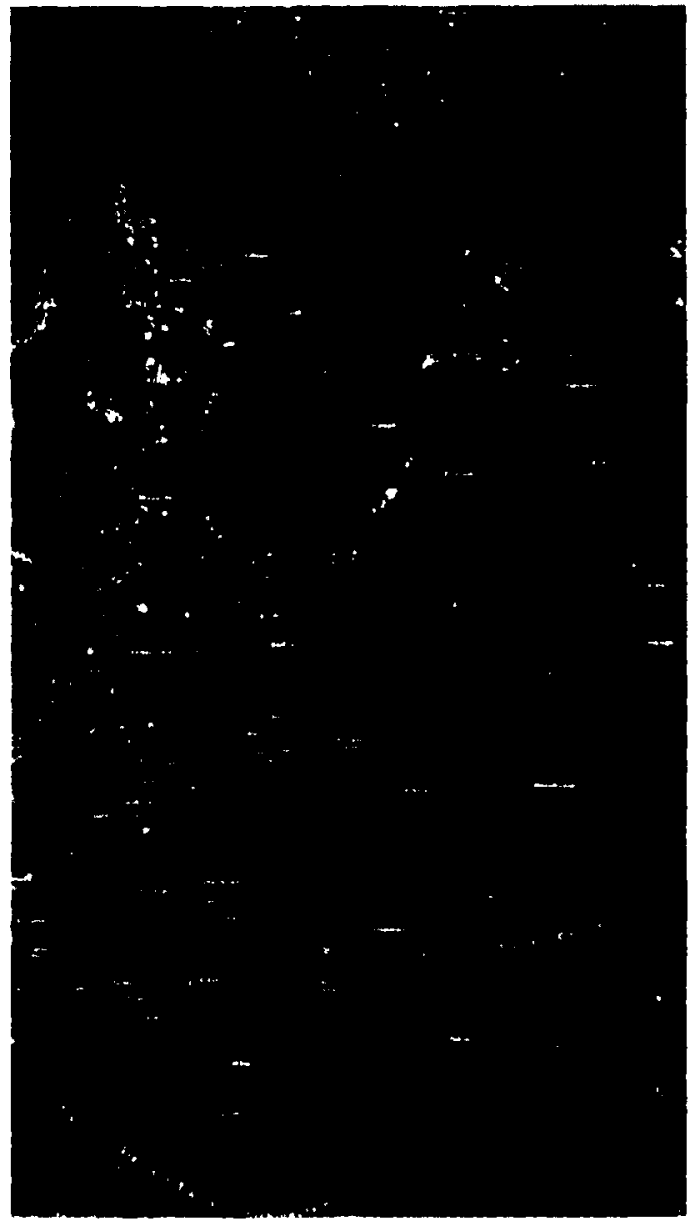

MEXICO CITY AND THE FORMER LAKEBED - Observatorio Panamericano 
and squatter brokers." Informal venders occupy areas planned for pedestrian or vehicle circulation because urban design doesn't include spaces for these vendors. This is why, when hawkers appear around planned developments such as Santa Fe in Mexico City, the police force has to be deployed to evict them in an attempt to 'reclaim' public spaces. Tiwari proposes that "If planners accept the heterogeneous labour market and the need for planning heterogeneous housing, public spaces and mobility solutions, the management of informal processes in urban spaces may improve., ${ }^{13}$

Despite the problems of irregular settlements, government and private initiatives have also generally failed to provide an adequate solution for low-income citizens. According to Connolly, many public housing projects throughout Mexico City are becoming slums. "Inadequate self-administration of these projects has led to lack of maintenance, invasion and degradation of public space, structurally dangerous alterations and bad neighbourhood relations." According to Connolly, "All of this is aggravated by the original cheap construction, low space standards and the increasing impoverishment of their working-class occupants, smitten by unemployment, alcohol and drug dependency, social violence and high crime

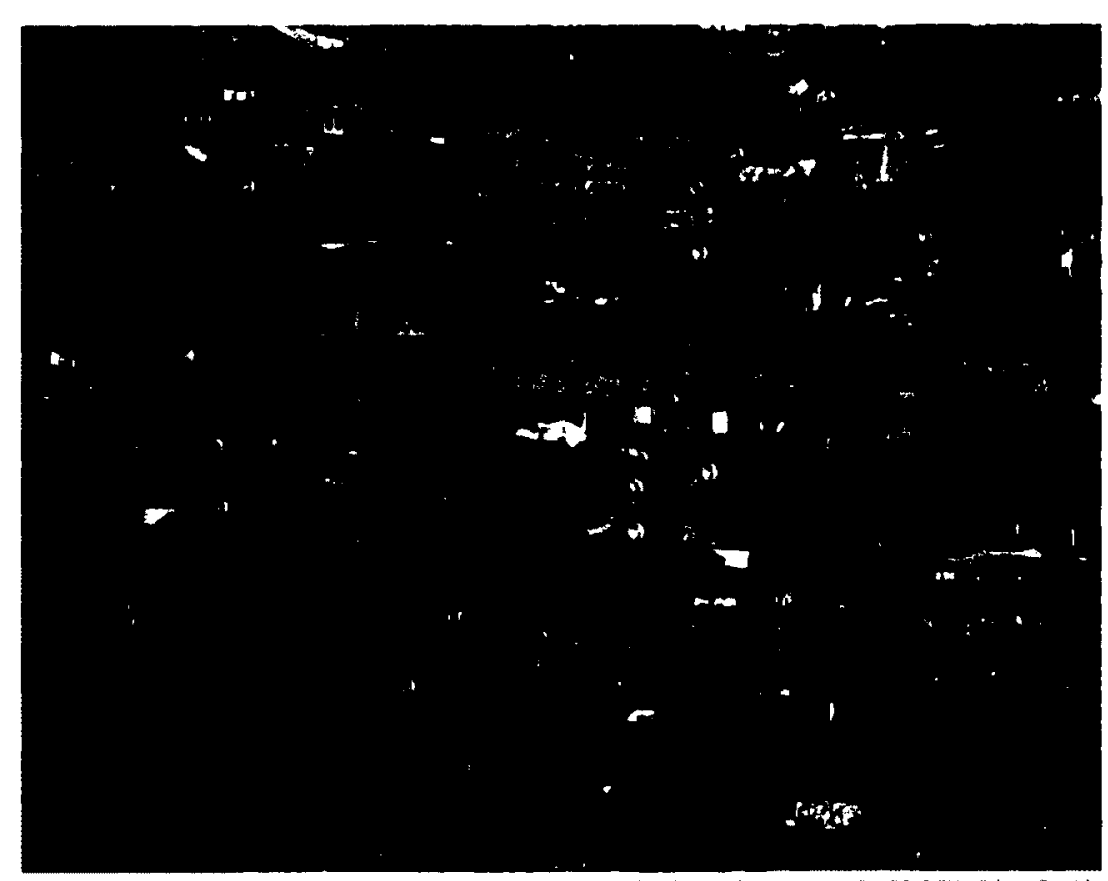

COLONIA POPULAR IN MEXICO CIYY - Edgar Garrido 
rates." ${ }^{14}$ As a result much of the housing that was conceived as viviendas dignas (decent homes) is deteriorating into slums. New housing projects are being built by comprehensive developers on a massive scale - up to six thousand units at a time - mostly on the extreme periphery, for people with access to the credit systems. Connolly describes the houses and individual plots as "miniscule", with developers focusing instead on public space such as roads - implying long walking distances to services and public transportation. "And, of course," describes Connolly, "there is a parking space for each house: a foresight into the car-dependent future this kind of urbanisation is creating". ${ }^{15}$

In contrast, the advantages that informal settlements offer in comparison to such public housing projects are flexibility and relatively large plots that accommodate extended families and second or third generations, a crucial consideration in Mexico's family-focused society. In addition, irregular settlements provide a social heterogeneity which is both the cause and effect of spontaneous neighborhood improvement. ${ }^{16}$

In general, the response of various levels of government to irregular settlements in Mexico City has been more supportive than repressive. Local government policy has been mainly laissez faire or even encouraging, with some notable exceptions of mass evictions. According to Connolly, "Once established, a colonia popular will normally encounter few problems in obtaining electricity, although basic infrastructure may take longer depending on the settlement's location, terrain and other localized factors." 17 The costs of such developments are covered by the inhabitants and the local governments with federal subsidies for certain items in the case of some upgrading programs. This supportive policy is due both to the inability of local governments to prevent unauthorised land occupations, and to the political and economic benefits that the clientelistic culture fostered by irregular land possession has for governments and politicians. ${ }^{18}$

Connolly. Priscilla. "Understanding Slums: Case Studies for the Global Repon 2003." Op cit

18. Connolly. Priscilla. ibid. 


\section{CHIMALHUACAN}

A prime example of this irregular urban growth is Chimalhuacán, a municipality located in eastern Mexico City. Chimalhuacan has endured higher demographic growth during the last four decades (an average of $9.85 \%$ annually) than any other nucleus in the country. In most cases this accelerated growth has settled illegally and irregularly in places unfit for human development. ${ }^{19}$ According to the Panamerican Observatory- a non-profit organization that has promoted territorial research in Chimalhuacán- such irregular growth has led to an important shortage of basic infrastructure, facilities, green areas and public spaces, and has "unbalanced the urban and territorial sustainability of the municipality, sentencing its own capacity for economic growth and leading to irreversible ecological deterioration of the territory and an important decline in the quality of life of the inhabitants". ${ }^{20}$

Chimalhuacán was founded during the archaeological Aztec Phase II (1259) on the shores of Lake Texcoco, at the foot of the Chimalhuachi hills. After the Spanish conquest, the new colonizers found no use for the existing lagoon and drained most of the lake, coming to an end during the last third of the $20^{\text {th }}$ century. ${ }^{21}$

19. "Inegi.gob.mx - Instituto Nacional De Estadistica Y Geografia (INEGI)." INEGI. Web. 04 Mar. 2012. <http:/'www.inegi.gob.mx>.

20. Chimalhuacan, Mexico: How to Regenerate a Urban Fabric Resulting from Accelerated and Irregular Settlement Processes. Publication. Observatorio Panamericano Paisaje Territorio Arquitectura. 2011. Print.

21. "Lago De Texcoco." Los Dicciomurion Y Las Enciclopedias Sohre El Academico. Web. 12 Mar. 2012.

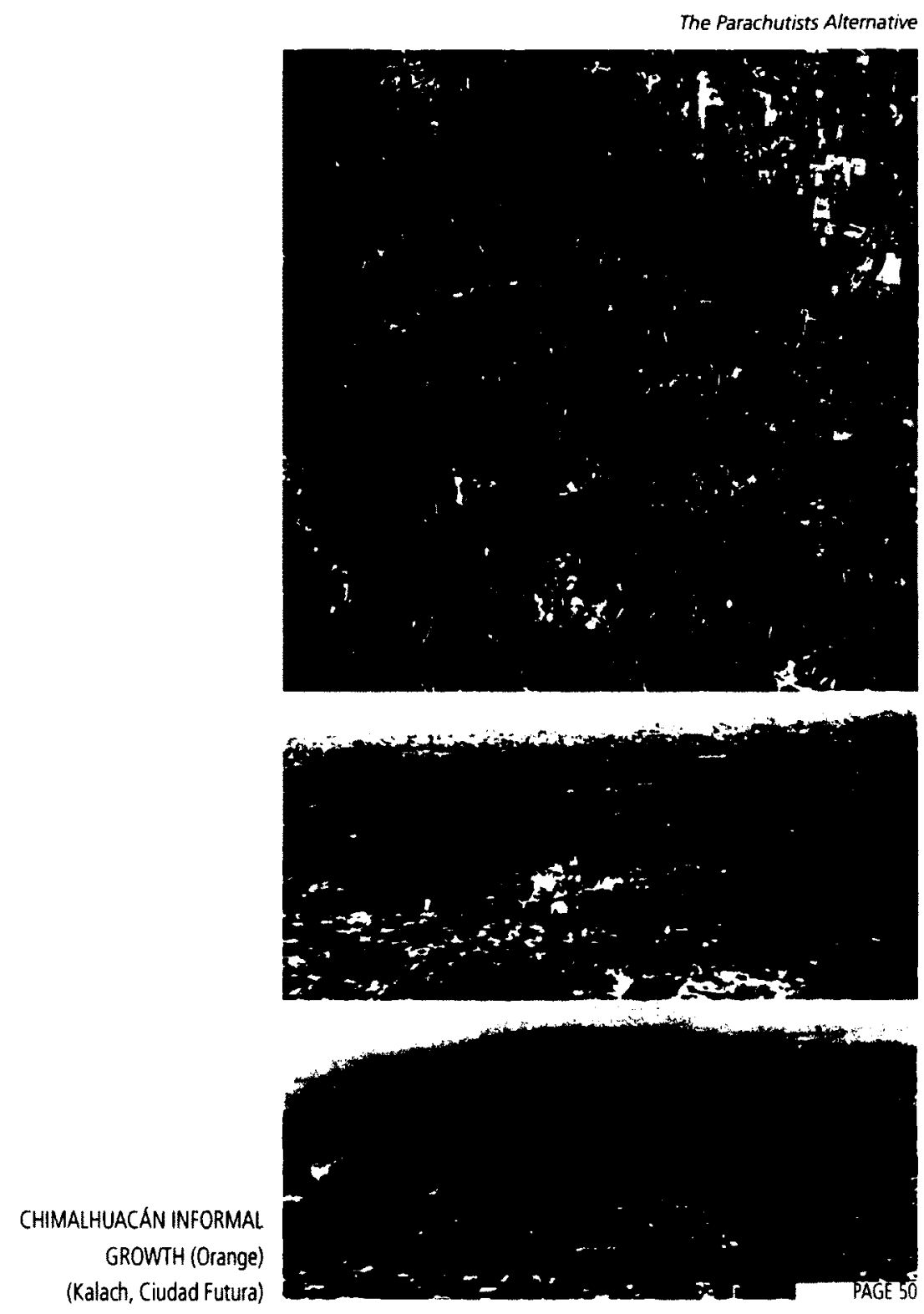


CHIMALHUACAN LAND USE

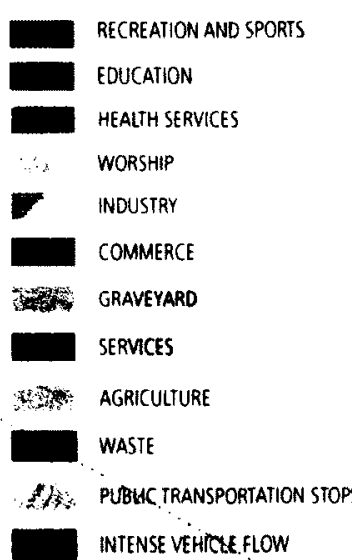

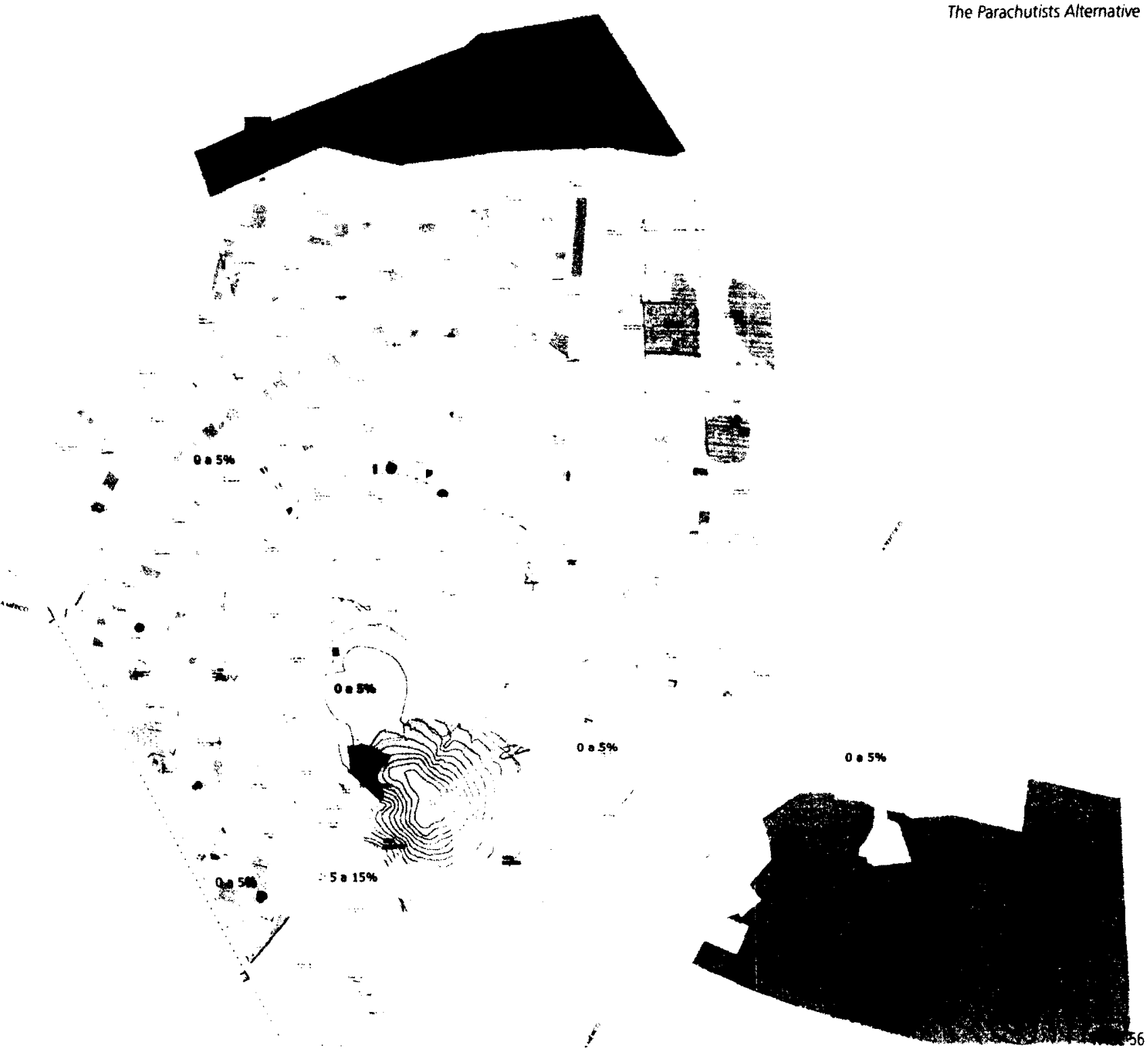

The Parachutists Alternative FLOOD PRONE AREA BODV OF WATER Iith AgRiCULIURAL LAND

GROWTH LMMITS

TOPOGRAPHY

COnflictarea

pastureland

want PARK

CANAL

$0.5 \%$ SLOPE

5-15\% SLOPE

$15.25 \%$ SLOPE

$+25 \%$ SLOPE

SUPPIY

HIGHWAY 
CHIMALHUACAN'S GROWTH OVER TIME
PLATFORM FOR URBAN INUESTIGATION MEXICO
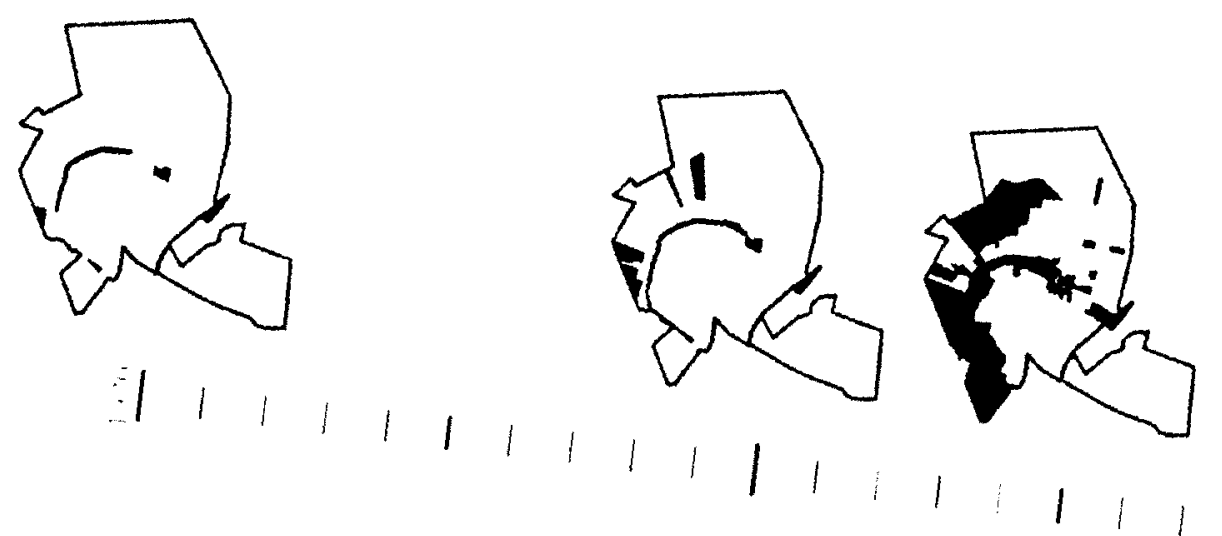

The Parachutists Aftemative
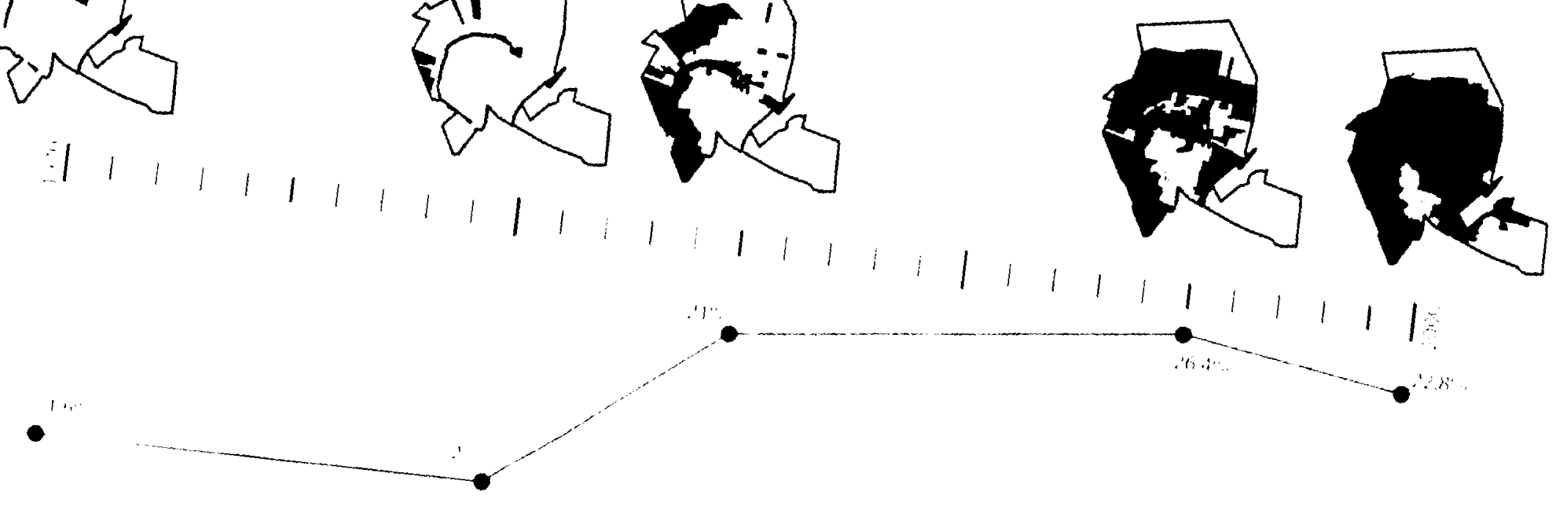


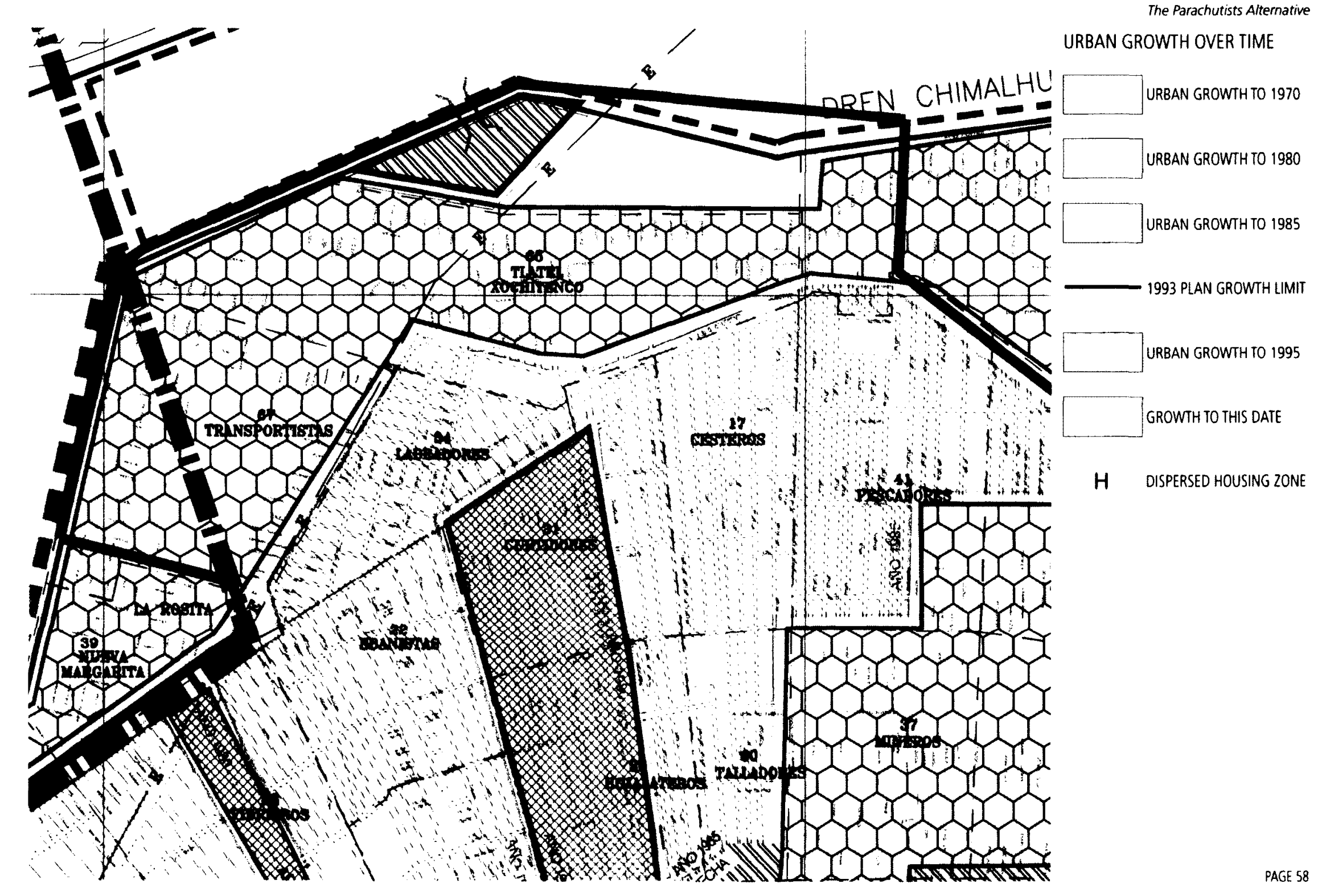




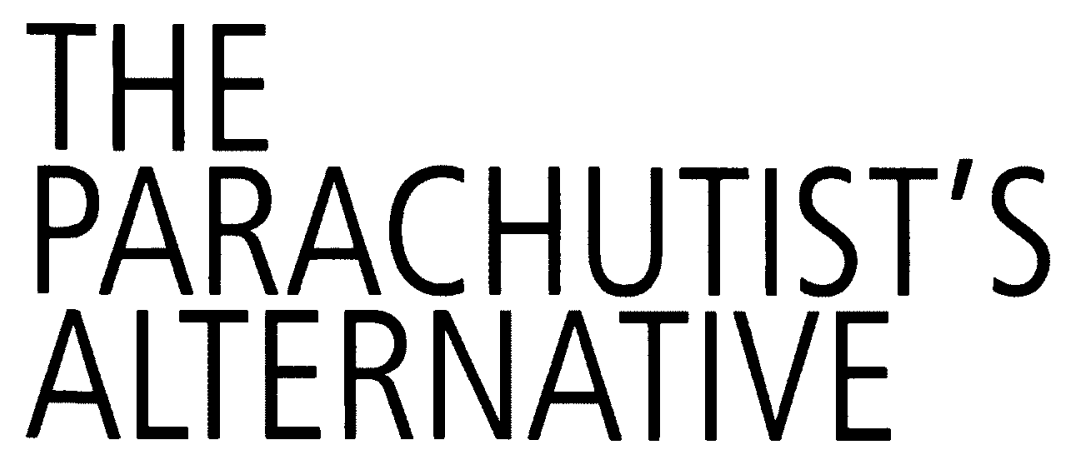

PORTFOLIO
The following project will be an urban intervention, based on a series of urban acupunctures, that will address some of the essential problems in Colonia "La Loba" (Also known as Tlatel Xochitenco) in Chimalhuacán.

"La Loba" developed irregularly over the last couple decades on the former Texcoco lakebed. The colonia is very underdeveloped - lacking basic services and infrastructure such as sewage and paved streets - and it is located on the periphery of Chimalhuacan's largest open-air dump. In order for the colonia to develop adequately over time, proposals for housing, waste-management and green community involvement spaces will be essential for a sustainable growth. 


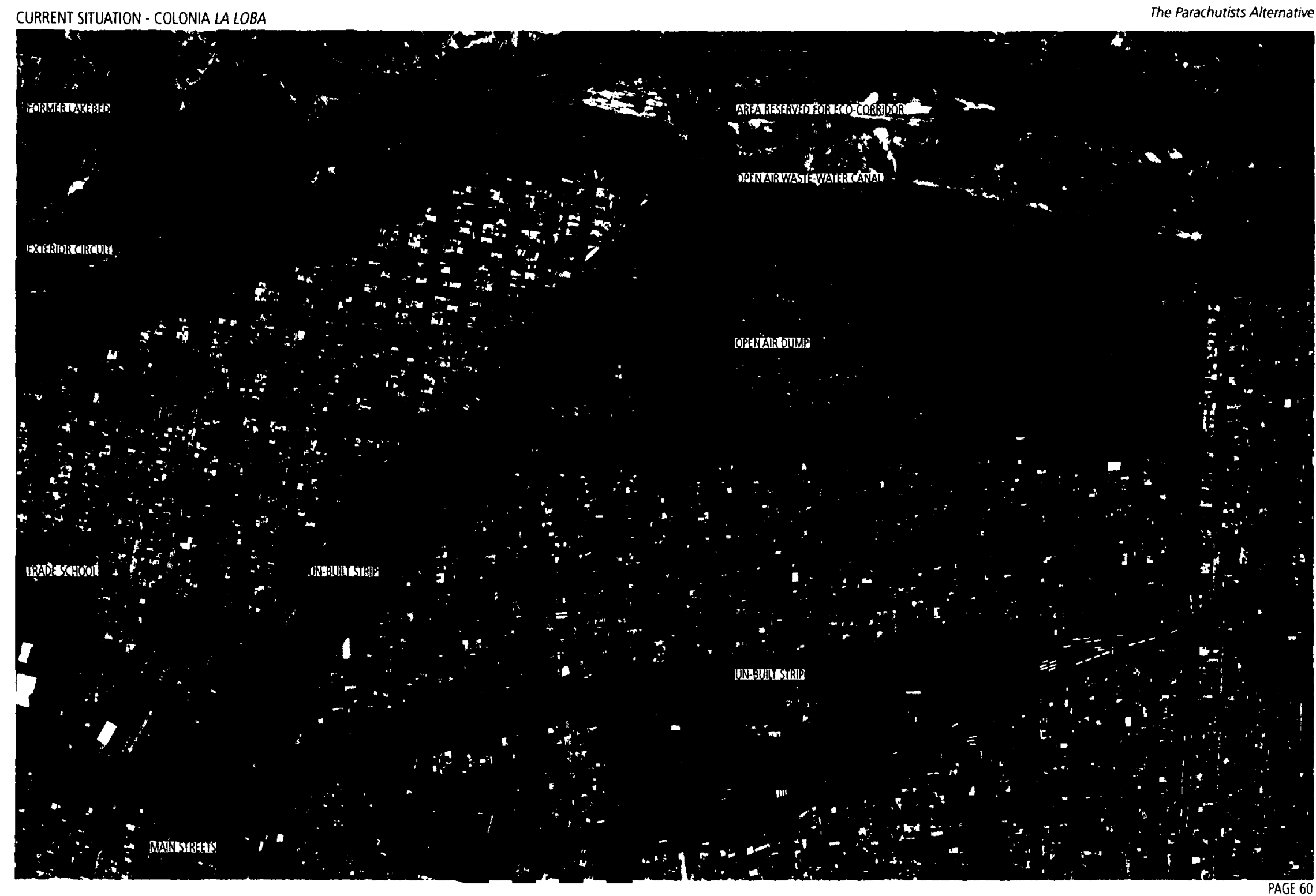


SITE PICTURES - COLONIA LA LOBA

LAKE TEXCOCO

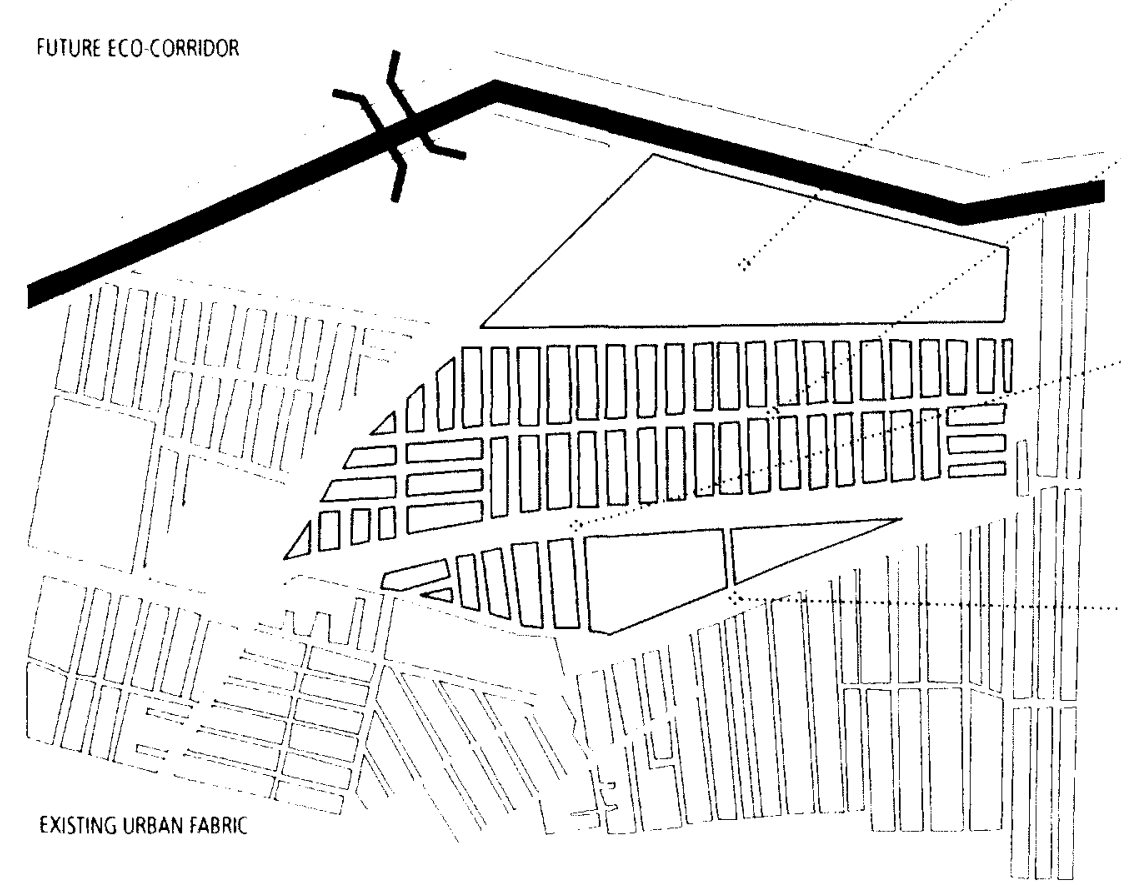

The Parachutists Alternative
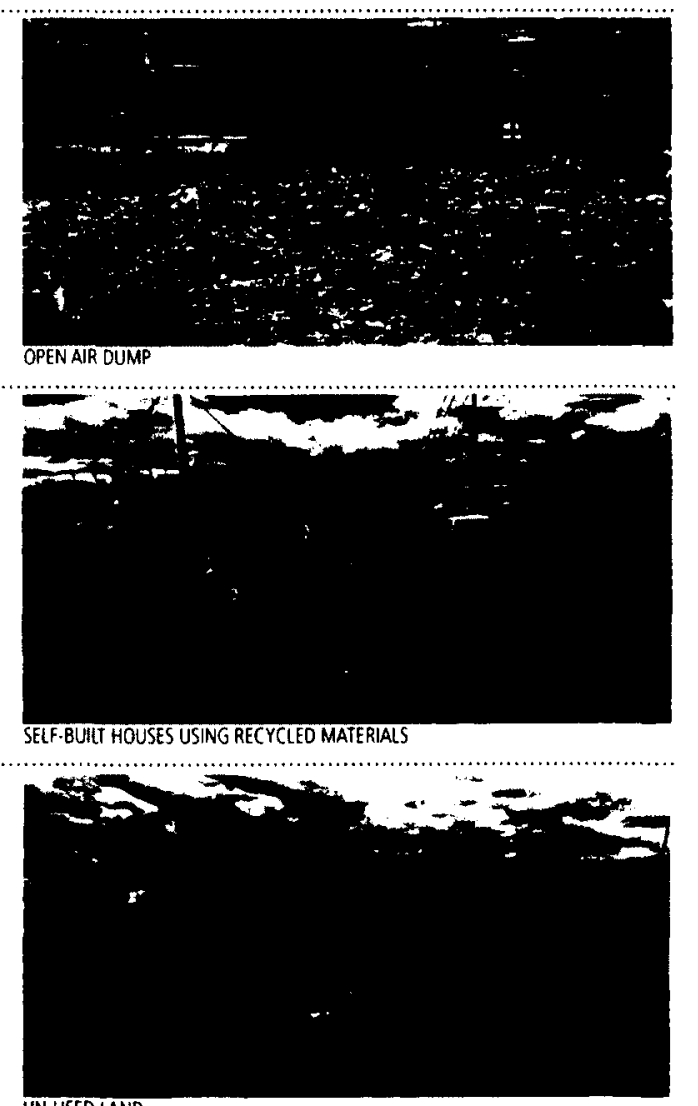

UN.USED LAND

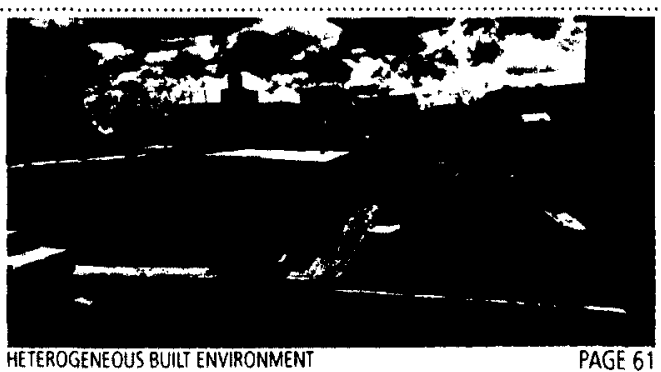




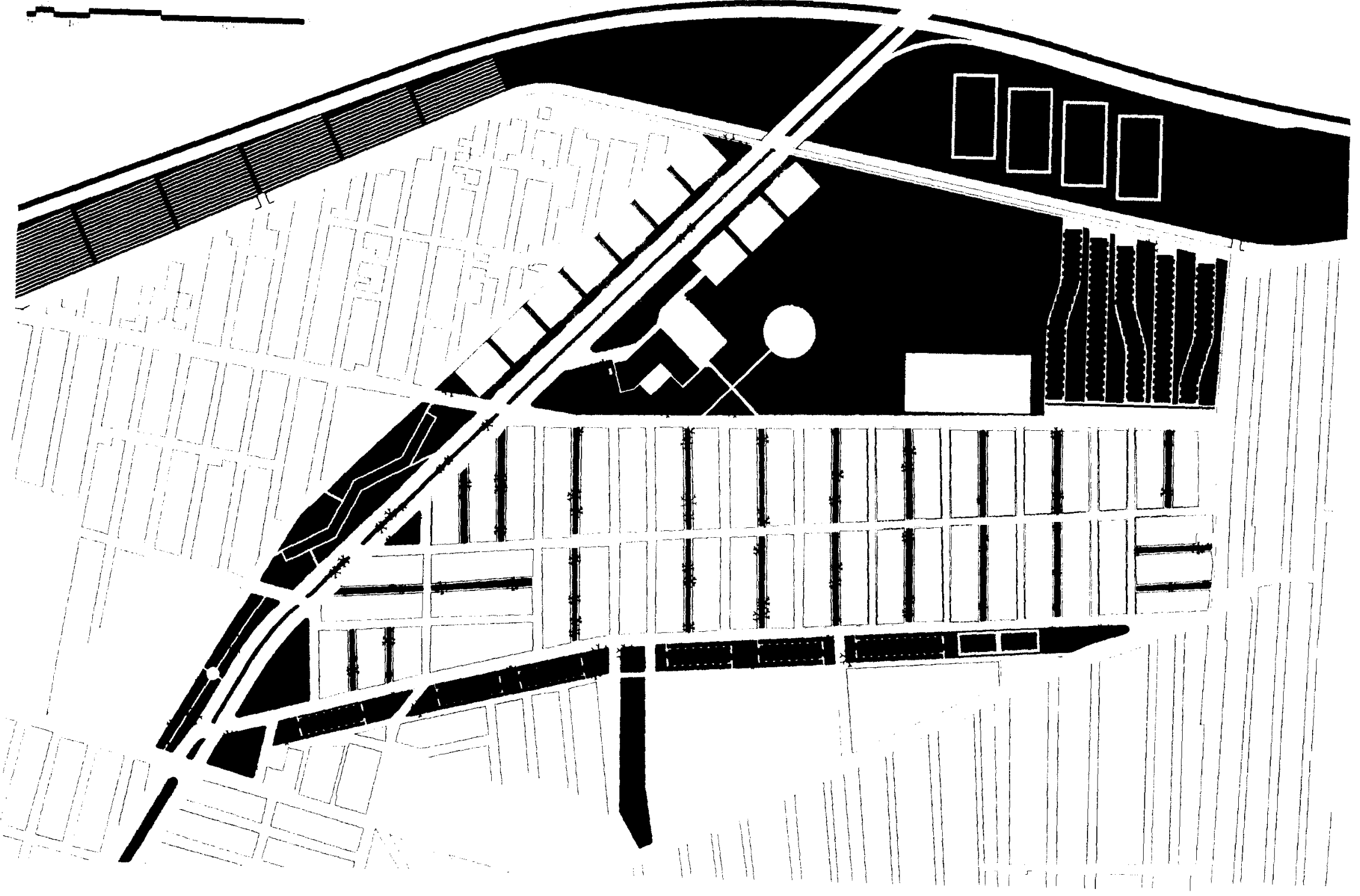




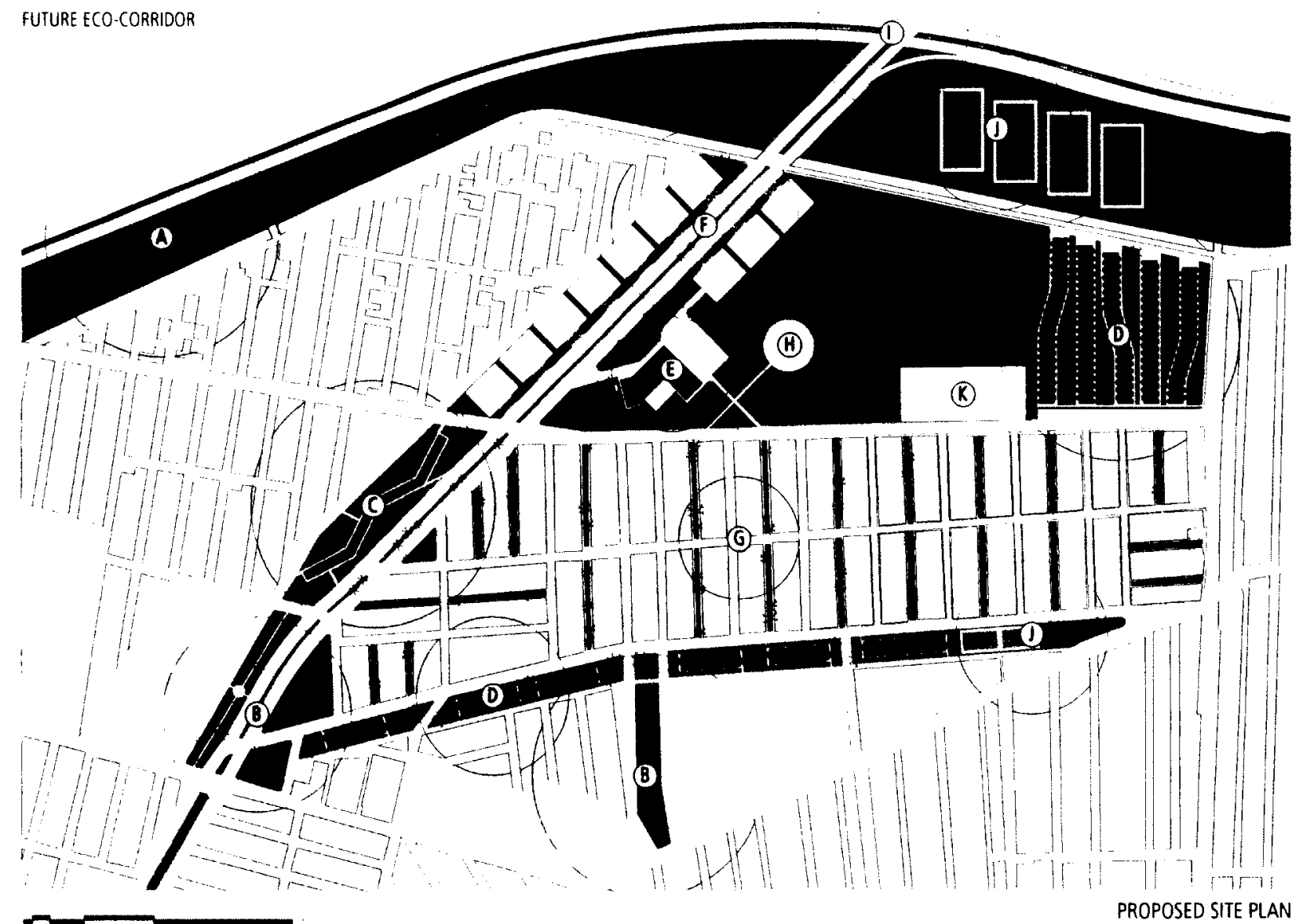

NEW PROGRAMMING + INFRASTRUCTURE

(A) AGRICULTURAL CO-OP

(B) IMPROVED ROAD INFRASTRUCTURE AND NEW

GREEN PUBLIC SPACE

(C) TIANGUIS (INFORMAL MARKET)

(D) NEW HOUSING (PROPOSED MODEL)

(E) WASTE TO ENERGY CENTRE + COMMUNITY

F SMALINDUSTRY

(6) TRANSFORM ROADS INTO PEDESTRIAN SIREETS

AND PUBLIC COURTYARDS

(H) PALENQUE (COCKPIT)

(1) NEW ROAD TO CONNECI WITH HIGHWAY

(1) SPORTS FACILIIIES AND GREEN AREAS

(R) PRIMARY SCHOOL

GREEN PUBLIC SPACE - UNMAINTAINED

GREEN PUBLIC SPACE - MAINTAINED

EXISTING BUILDINGS

PROPOSED BUILDINGS 


\section{HOUSING}

Similar to the rest of Chimalhuacán, the housing situation in colonia La Loba is very complex. The Colonia takes name after Guadalupe Buendia Torres (La Loba), who for decades was the most important cacique (political boss) in Chimalhuacán. ${ }^{11}$ Buendia greatly influenced the shaping of Chimalhuacán's current image; she developed many informal settlements in the lower parts of Chimalhuacán such as Colonia La Loba, and controlled the vote of her followers in order to influence political leaders. Buendia was incarcerated in 2000 for murder charges, and since then her family's control over sectors of Chimalhuacán has been diminishing with changes in government and the political system..$^{02}$

The colonia La Loba was established without any basic public services such as drinking water, sewage, lighting, etc. indicating that it was developed without municipal authorization. The lots were sold by the informal developers - even though they lacked basic public services and the legality of the settlement was unclear - for prices ranging from 25,000 to 50,000 pesos. New inhabitants would give a down payment of 5,000 pesos and pay an additional 500 to 1000 pesos a month for their lots. If people fell behind on their payments, the lot would be taken

01. "Sociedad Y Poder." Sociedad Y Poder. Web. 31 Mar. 2012. <http://sociedad.wordpress. com/2005/12/10/la-loba-retrato-de-un-sistema-corrompido-2/s.

02. "Arqueologia De La llegalidad." Arqueologia De La llegalidad. Web. 31 Mar. 2012. <http://www. etraslibres.com/revista/convivio/arqueologia-de-la-ilegalidad>. away and resold to another buyer. ${ }^{03}$

Many of the inhabitants of this colonia work in the dump sites as informal garbage sorters (pepenadores) - another industry that was informally controlled by Buendia. These people build their homes mainly out of recycled materials scavenged in the dumps, creating unsafe and unsanitary living conditions for these families. However, there have been some residents of the colonia that have been able to build more permanent structures, creating a heterogeneous urban fabric within the colonia.

The proposed building solution will act as a canvas - a frame which will provide structural integrity while allowing and encouraging future contingency. The housing proposal will empower the informal settlers - allowing them to alter, expand and appropriate their dwellings. In addition, the housing scheme isn't viewed as individual units, rather, it is viewed as a community of dwellings that can collectively reduce building costs and provide collective neighborhood spaces such as community kitchen/dining areas and collective laundry facilities. The proposed housing units will be located in unused sections of the settlement and on the lower parts of the new landfill. The housing proposals can also be incorporated into the existing urban fabric in places that are underdeveloped due to decades of corruption and a lack of personal resources.

03. "La Jornada." Defraudadas Por La Laba Y Hostigadas Por Ex Comuneros Sobreviven Cientos De Familias. Web. 31 Mar. 2012 <http://www.jornada unam. mx/2006/11/30/index.php?section=estados $>$. 
HOUSING

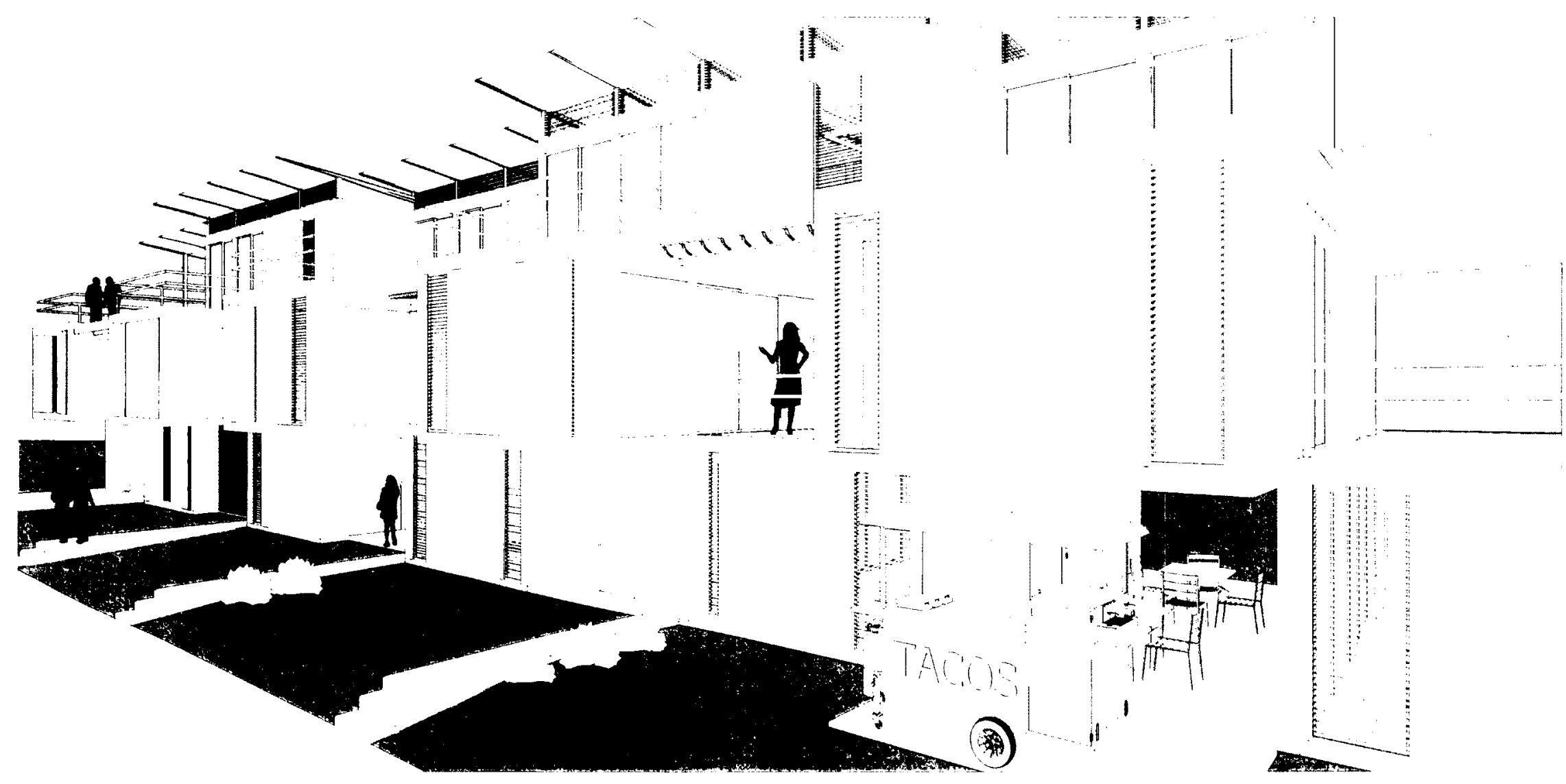


PARACHUTIST HOUSING

The housing situation in Chimalhuacán is heterogeneous; some of the existing houses have developed over time and have become safe and sturdy structures. On the other hand, there is a vast amount of dwellings that lack basic services, and their makeshift structure is assembled out of scavenged materials. These houses are highly prone to structural failure and natural disasters.

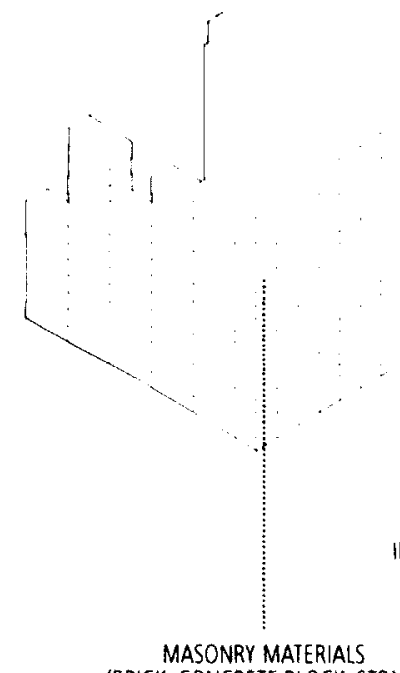
(BRICK, CONCRETE BLOCK, STONE)

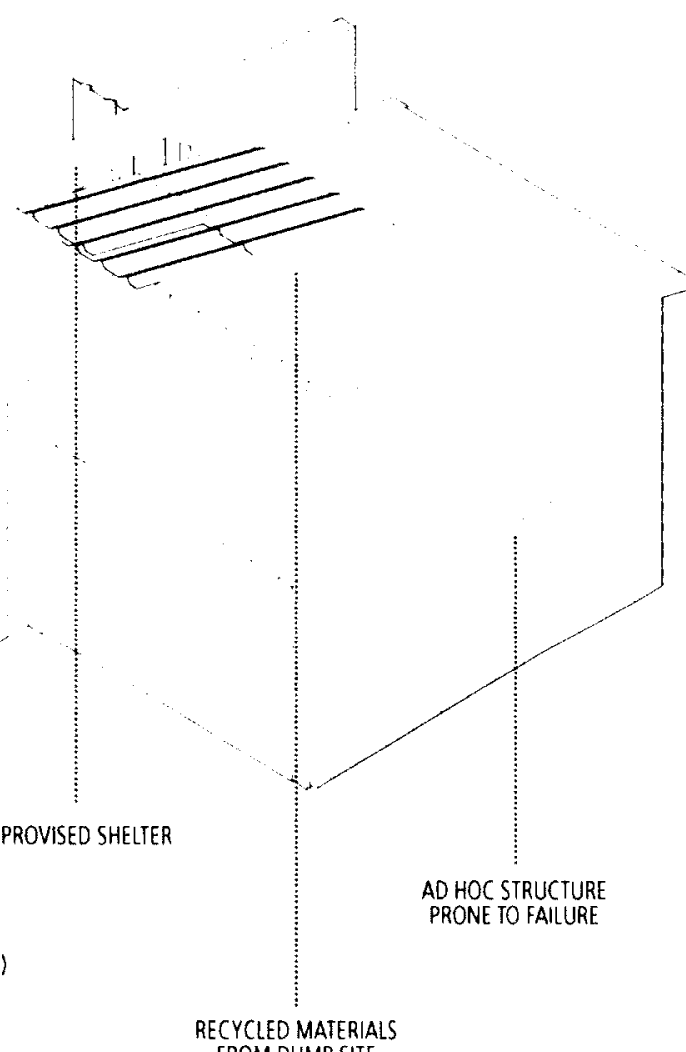

EXISTING PARACHUTIST HOUSING IN CHIMALHUACAN
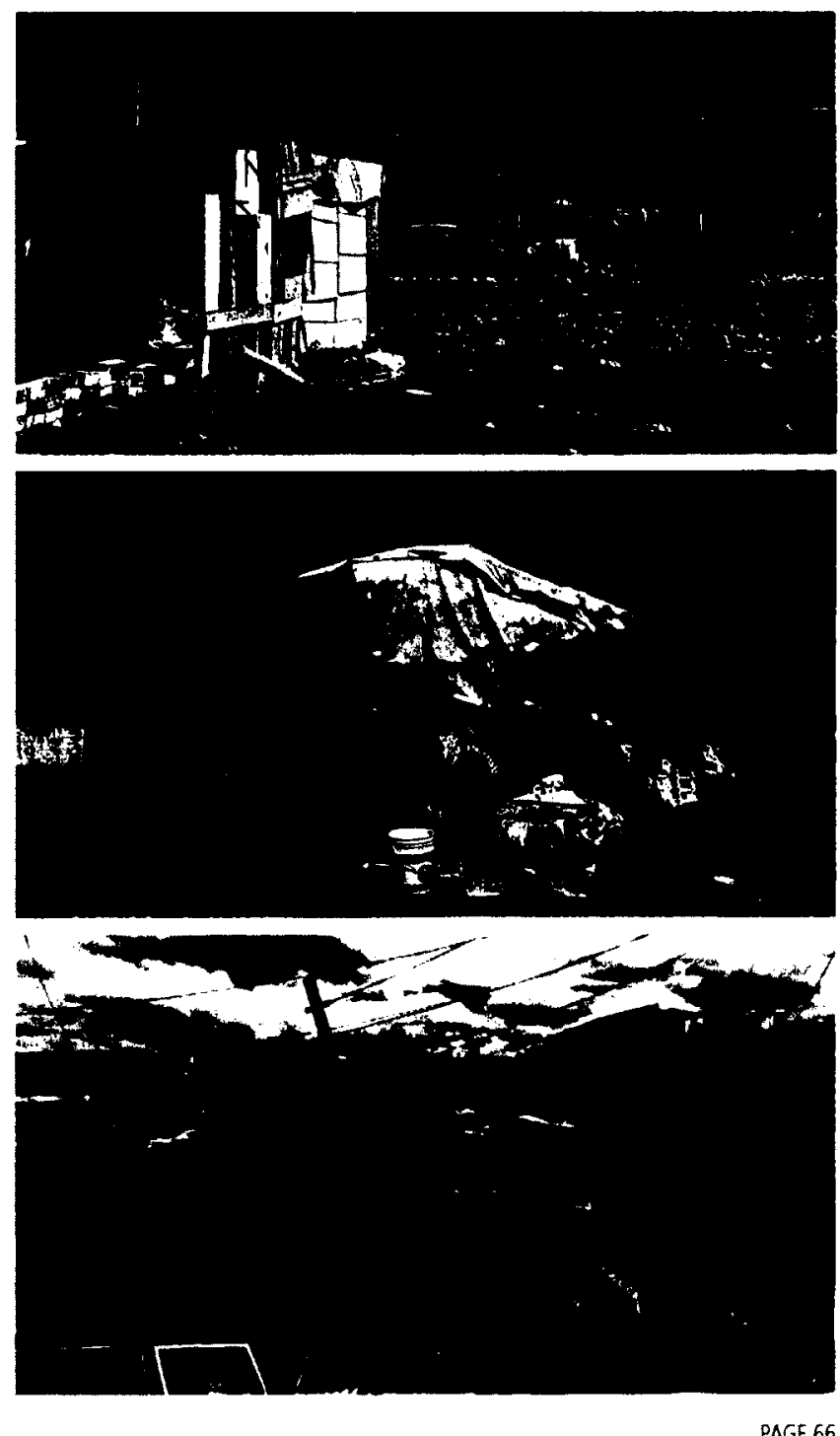
Housing is a highly political issue in Mexico and the government often engages in the housing market by providing credits and and stimulus to build low-income housing. However, quantity is often prioritized over quality in these developments resulting in serious problems such as re-settlement in marginalized locations, poor quality building materials, unstable structures and lack of public green areas. These housing options tend to offer minimal space inside the house, and future growth is expensive and unrealistic. Additionally, the housing units are built in in massive blocks and there is no unique or distinctive quality to these houses that can provide a sense of identity to their inhabitants.

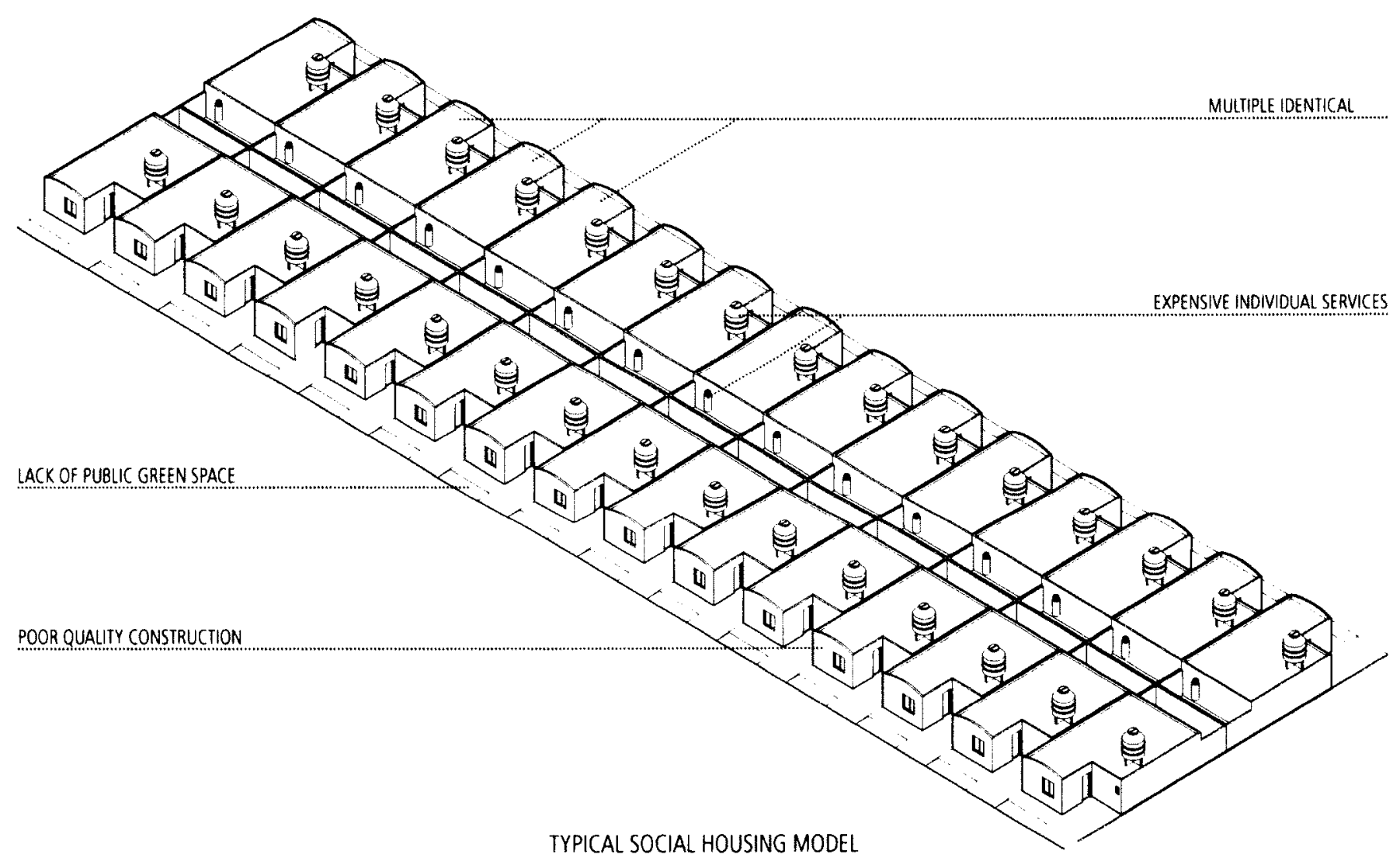




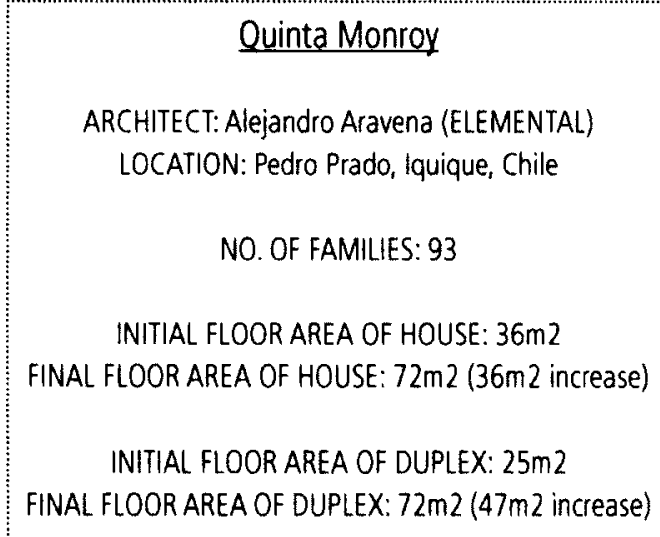

NO. OF FAMILIES: 93

INITIAL FLOOR AREA OF HOUSE: $36 \mathrm{~m} 2$ FINAL FLOOR AREA OF HOUSE: $72 \mathrm{~m} 2$ (36m2 increase)

INITIAL FLOOR AREA OF DUPLEX: $25 \mathrm{~m} 2$ FINAL FLOOR AREA OF DUPLEX: $72 \mathrm{~m} 2$ ( $47 \mathrm{~m} 2$ increase)

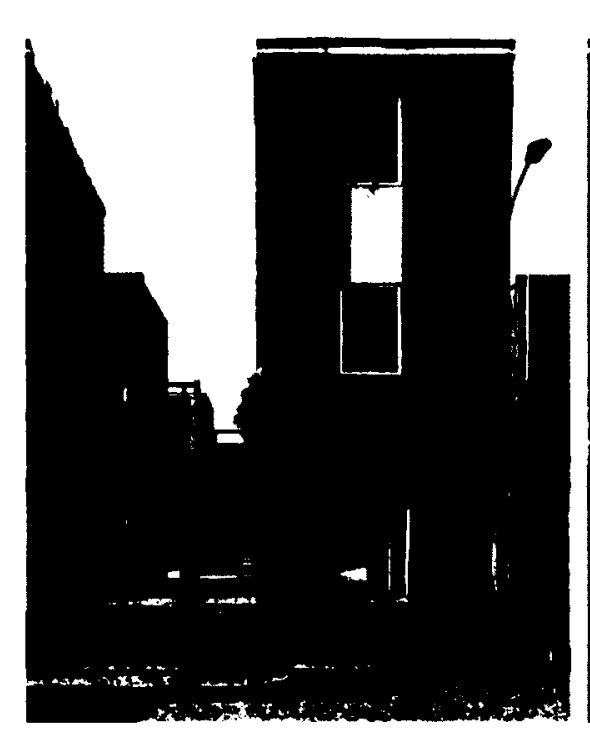

QUINTA MONROY GROWTH OVER TIME
The housing component of this thesis is influenced by ELEMENTAL's Quinta Monry social housing scheme in Iquique, Chile. Quinta Monroy's housing scheme consists of units with an initial surface area of $36 \mathrm{~m} 2$ (ensuring the project would fall withing the budget); and each home would be left unfinished to allow for furture additions in accordance with the needs of each family. This would guarantee the diversity and individualization program and the social structure of the design.

An important thing about Quinta Monry is that it successfully addresses the problem with social housing - its inability to grow in value. A year after the reoccupation of Quinta Monroy, the land price per square meter rose from 1.2 UF to 4UF. Simply through the revaluation of the land, wealth has been transferred into the hand of the families and the social housing strategy is seen as an investment and not as a cost.
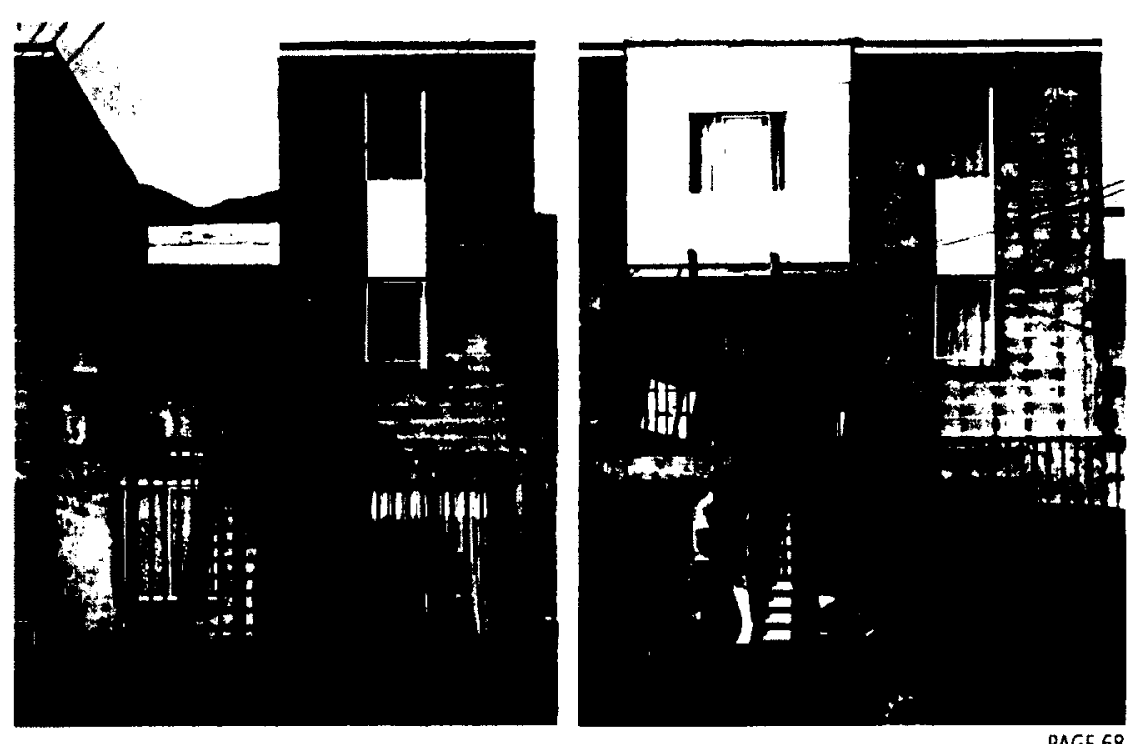
CASE STUDY - ELEMENTAL QUINTA MONROY
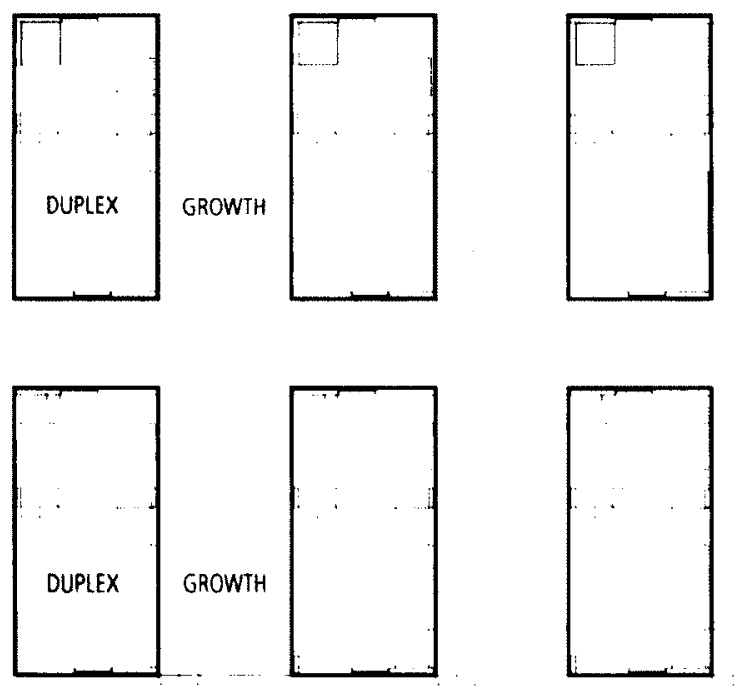

$\infty$

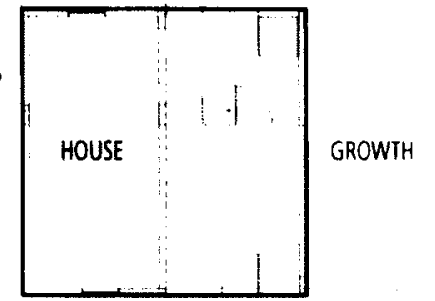

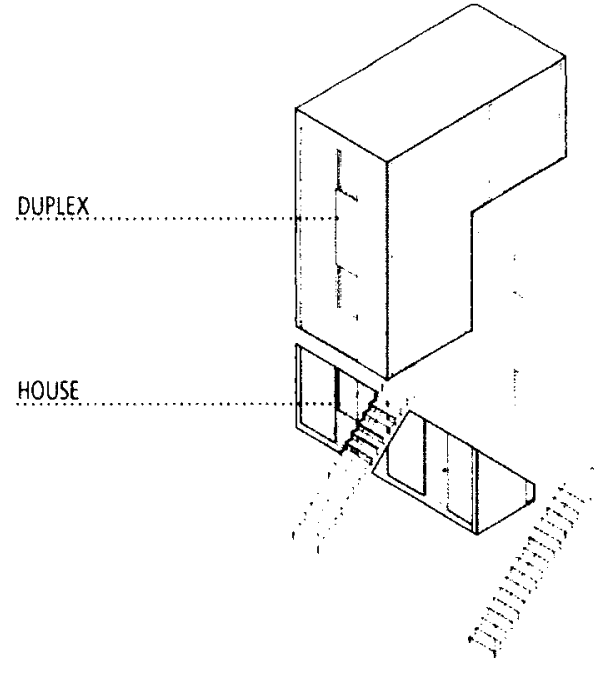

UNITS
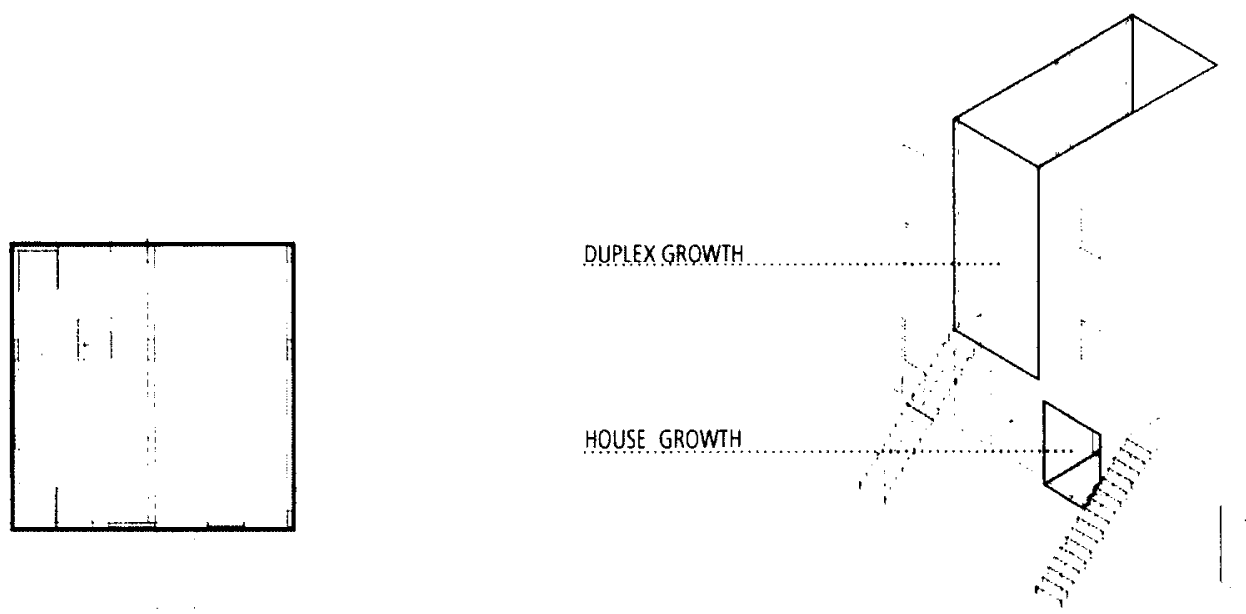

UNIT GROWTH

The Parachutists Alternative

FLOOR PLANS 
HOUSING PROPOSAL

The proposed housing scheme in Chimalhuacán consists of three units stacked on top of each other. Each unit will have an initial average floor area of $40 \mathrm{~m} 2$ and this area can easily double in size with the addition of non-loadbearing walls. The initial units will consist of a wet core that includes a washroom and a kitchenette, and a large room that can be divided into living and sleeping spaces. These initial units will be built by building professionals, while the additions can easily be done by the homeowners to customize the units to their individual needs, which may include additional bedrooms, larger living spaces, or a small business.

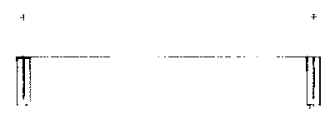

.

UNIT O1. EMPTY TERRACE

$9.0 \quad 11$$$
\text { T. }
$$

4.5

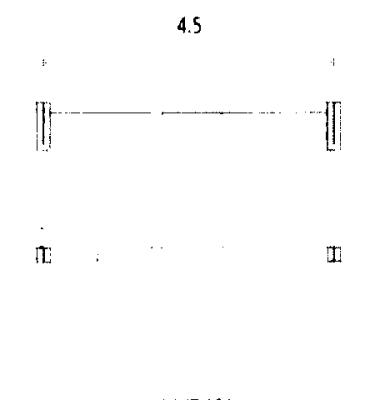

UNIT 101 - GROWTH

UNIT 10

9.0

I

th

$\|$


PROPOSED HOUSING SCHEME - FLOORPLANS

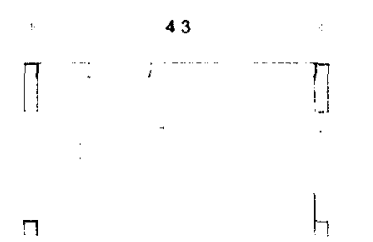

$90 \quad$ UNIT 200- EMPTY

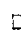

1

7

$\square$

$\Gamma$

UNIT 300

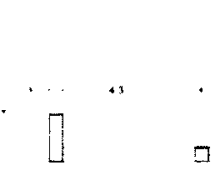

UNII 300. EMPTY

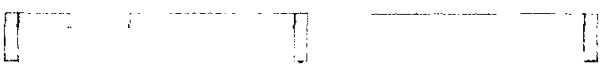

$\square$

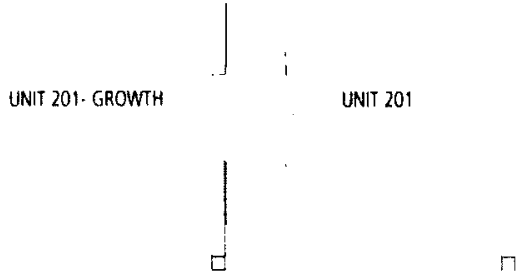

$\prod$
SECOND FLOOR PLAN

The Parachutists Alternative

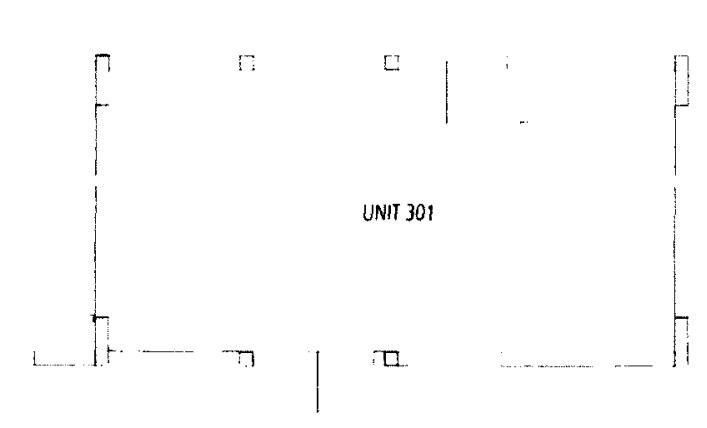

UNIT 301-GROWTH BALCONY 

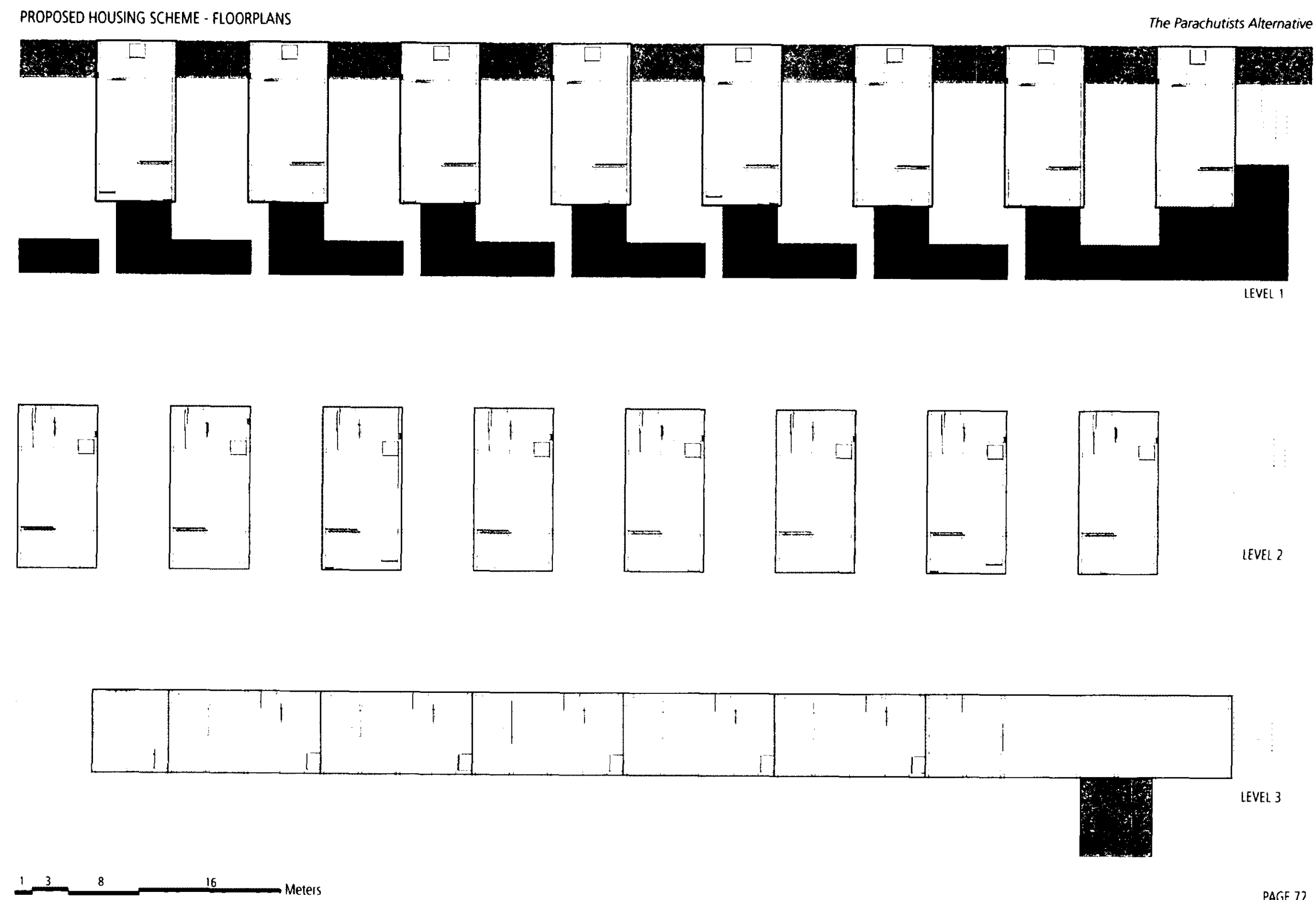
1 UNIT
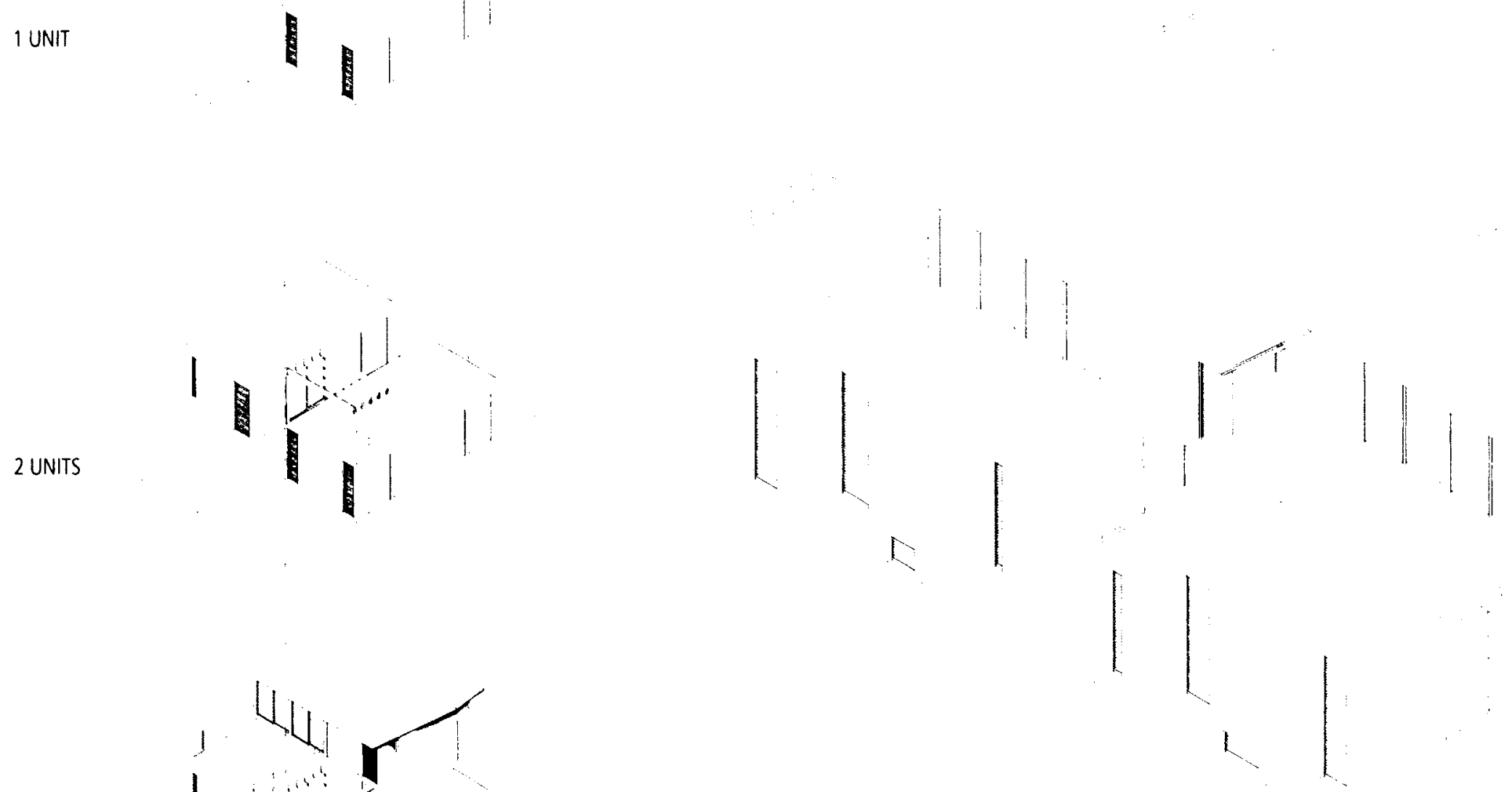

3 UNITS

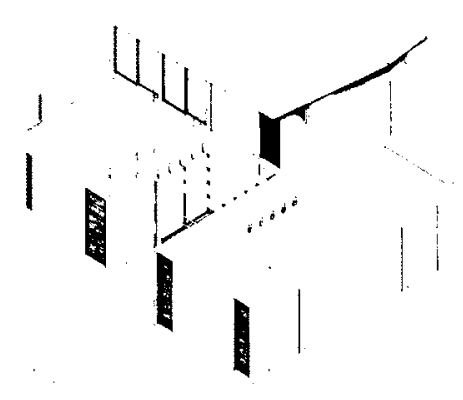




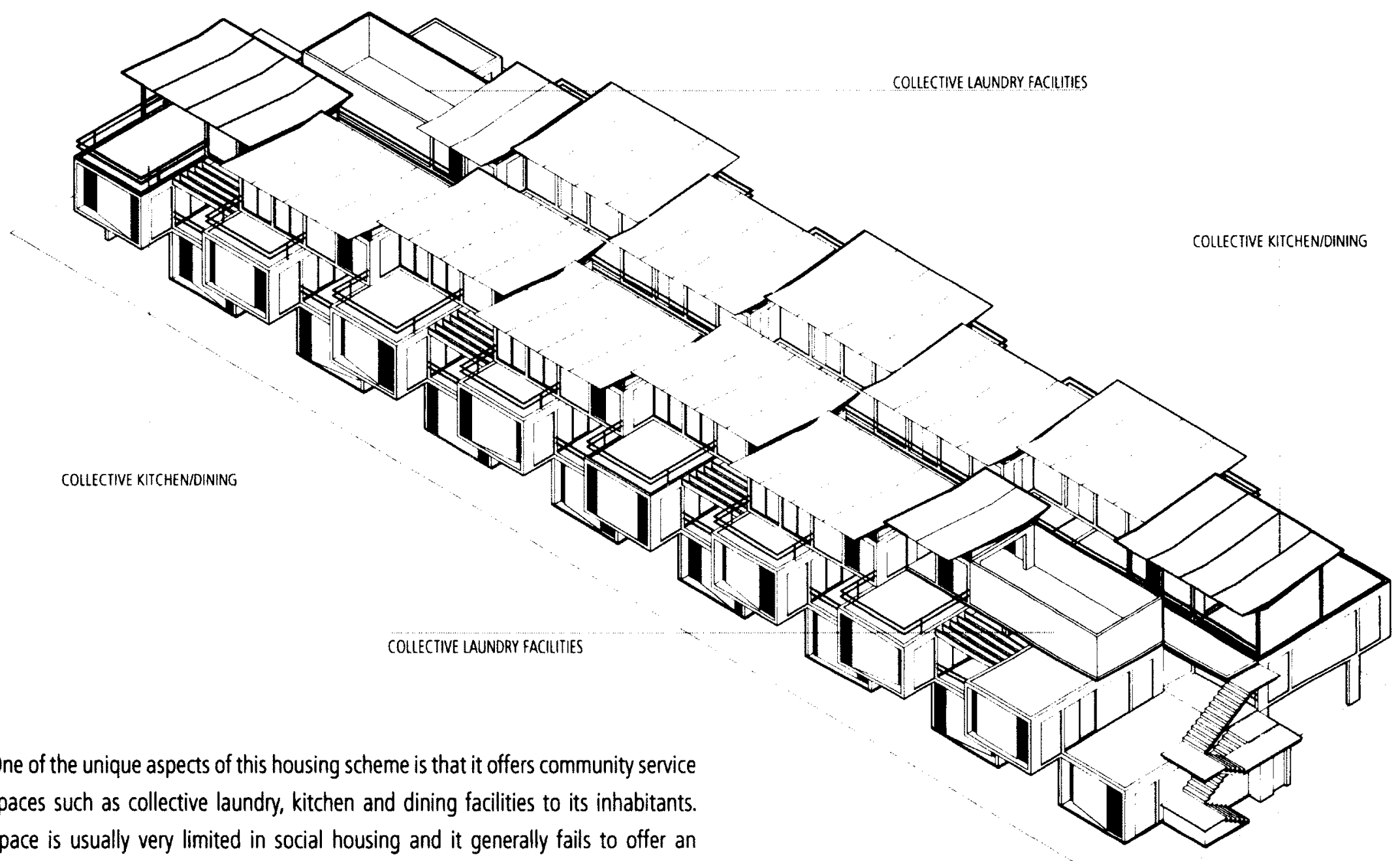
adequate solution for these types of services. Though families have basic services provided in their units, these collective spaces will provide extended space for laundry, meeting, socializing and family events. 

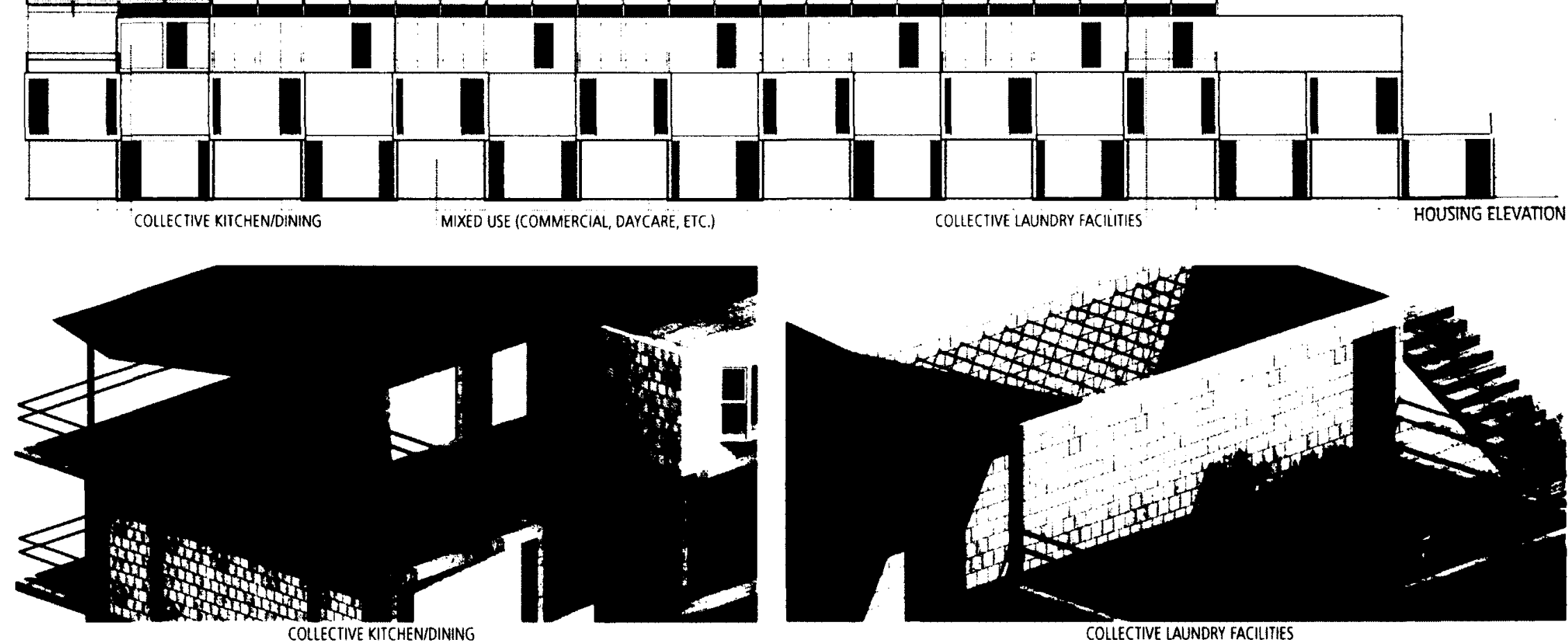
COLLECTIVE KITCHEN/DINING
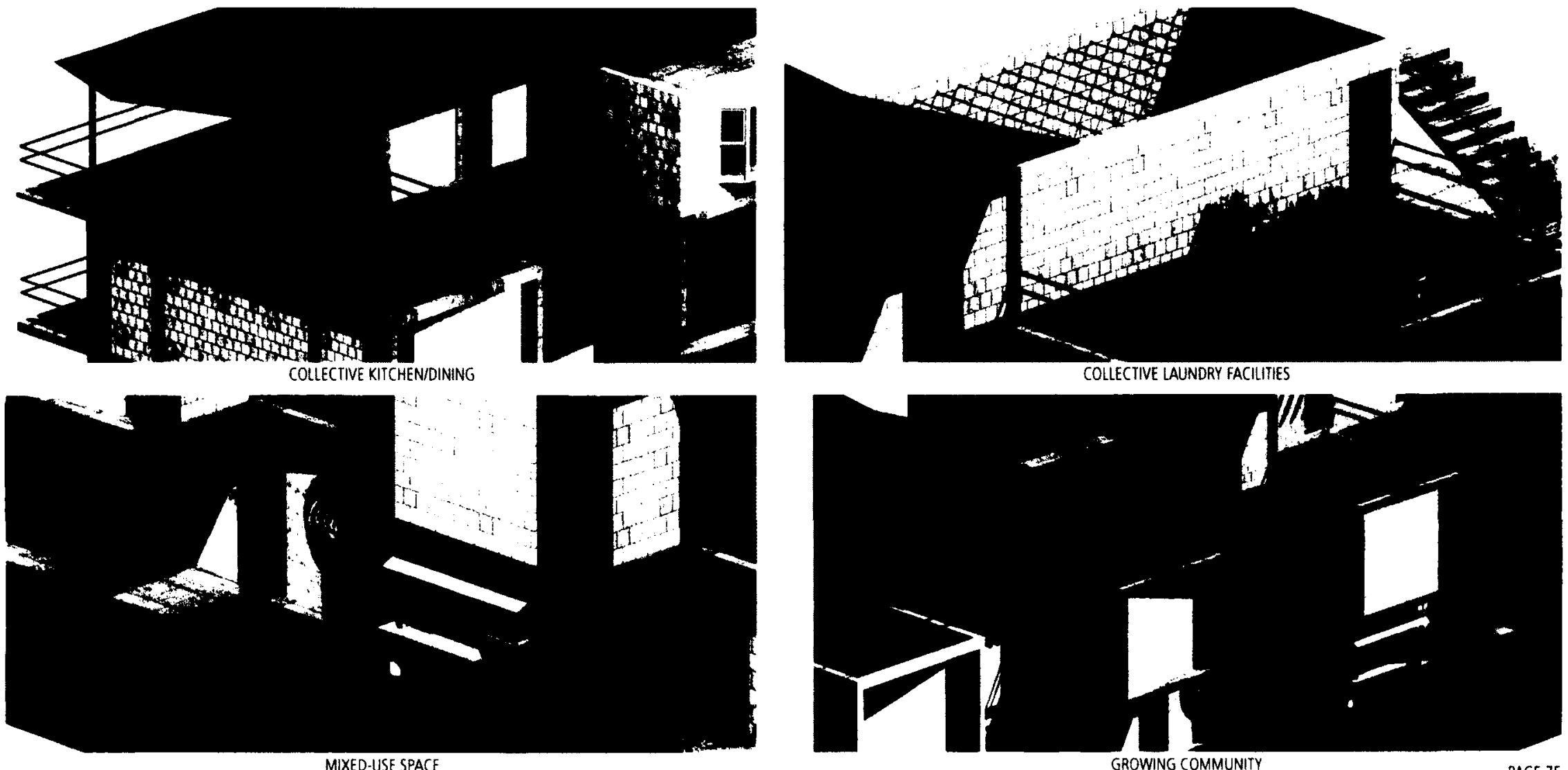


\section{ADAPTABILITY}

Parachutist settlements such as Chimalhuacán are usually located on undesirable and inhospitable sites where they can settle without being removed. These sites can present problems such as difficult topographies, weak soil and flood prone areas. Therefore, social housing solutions must be adaptable to these conditions.

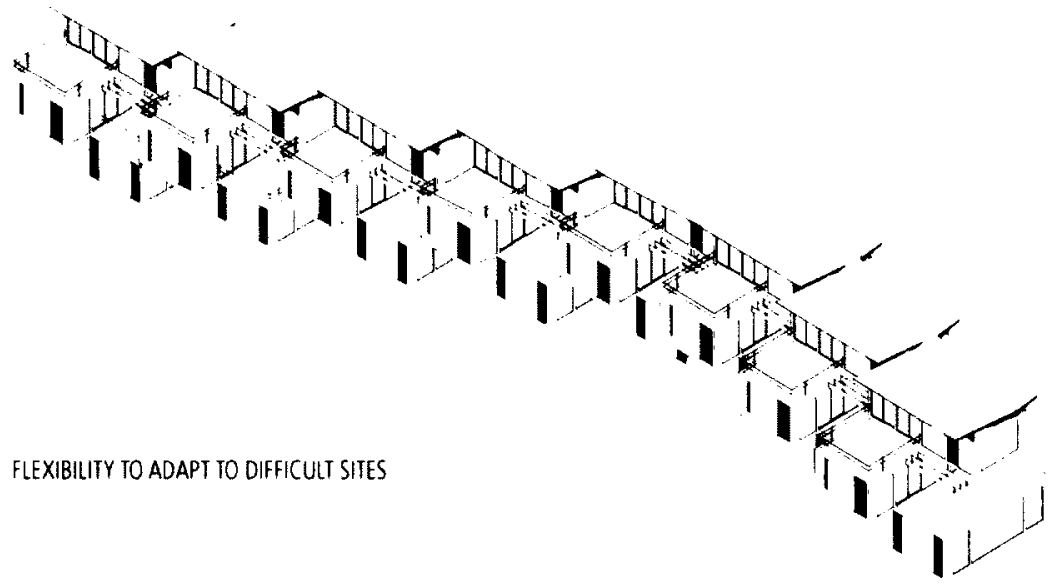

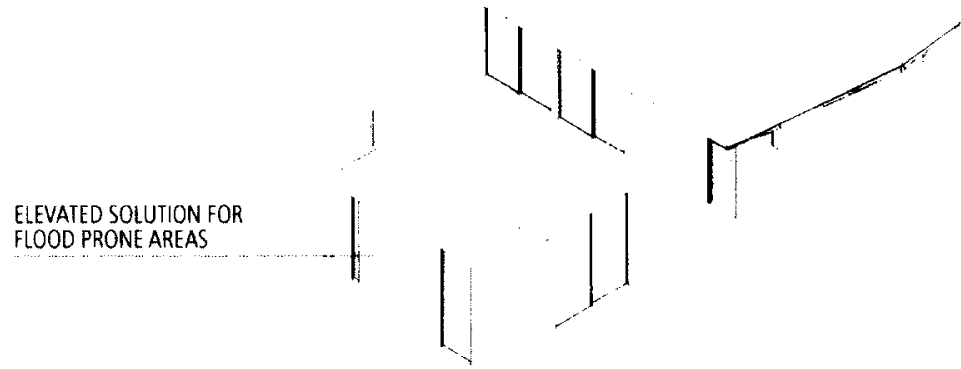

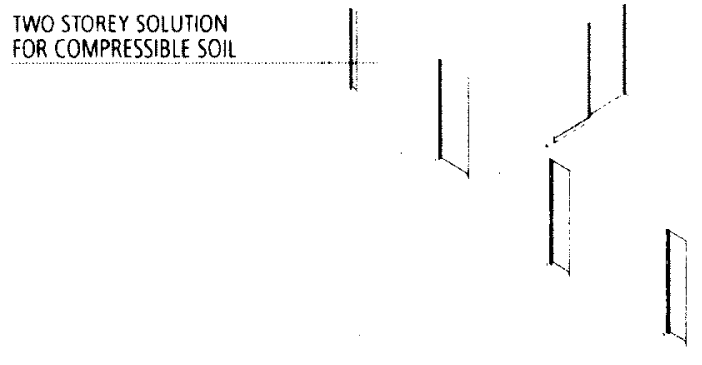




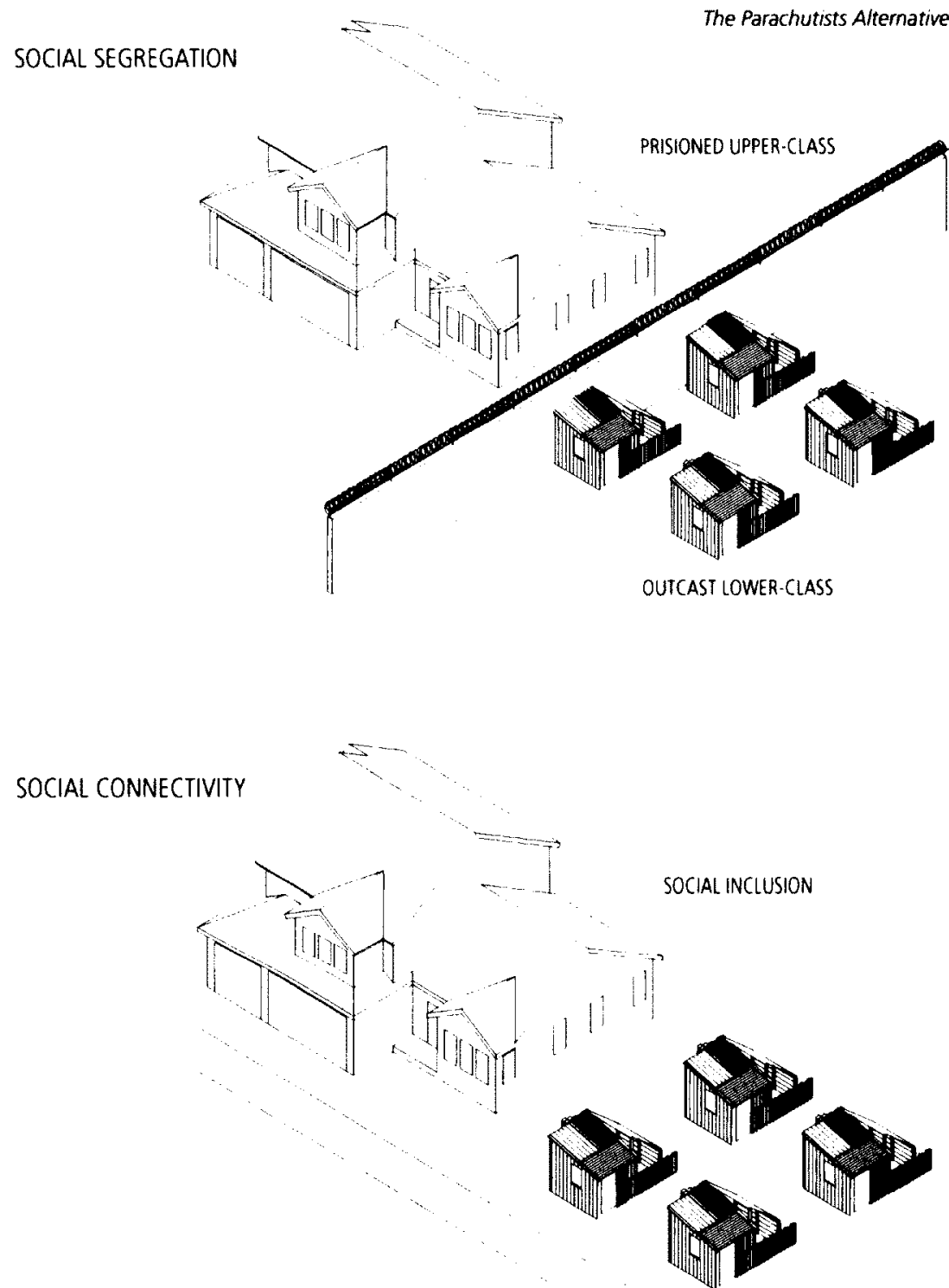




\section{TYPOLOGY COMPARISION}

TRADITIONAL TYPOLOGY (GOVERNMENT - DEVELOPER)

NUMBER OF UNITS: 30 UNITS

AVERAGE BUILT FLOOR AREA PER UNIT: $45 \mathrm{~m} 2$

AVERAGE BUILT AREA PIUNIT AFTER SIMPLE EXPANSION: Non-Existent

COMMUNITY SERVICE SPACES: Non-Existent

PUBLIC GREEN SPACE: Non-Existent

CONSTRUCTION COST PER M2: $\$ 3,638.00^{*}$

TOTAL BUILT AREA: $1350 \mathrm{~m} 2$

APROXIMATE CONSTRUCTION COST: $\$ 4^{\prime} 911,300.00$

COST PER UNIT: $\$ 163,710.00$

ALTERNATIVE TYPOLOGY

NUMBER OF UNITS: 42 UNITS

AVERAGE BUILT FLOOR AREA PER UNIT: $40 \mathrm{~m} 2$

AVERAGE BUILT AREA PIUNIT AFTER SIMPLE EXPANSION: $80 \mathrm{~m} 2$

COMMUNITY SERVICE SPACES:

(2) COLLECTIVE KITCHEN + DINING

(2) COLLECTIVE LAUNDRY

PUBLIC GREEN SPACE: $3,402 \mathrm{~m} 2$

CONSTRUCTION COST PER M2: $\$ 4,307.00^{*}$

TOTAL BUILT AREA: $1003 \mathrm{~m} 2$

APROXIMATE CONSTRUCTION COST: $\$ 4$ 4328,535.00

COST PER UNIT: $\$ 103,060.00$

*http://www.cmicmty.org.mx/documentos/socios/MIC.pdf

* All prices shown are in Mexican Pesos. 1 CAD: 12.9 MXN (03/05/2012
TRADITIONAL TYPOLOGY (GOVERNMENT - DEVELOPER)
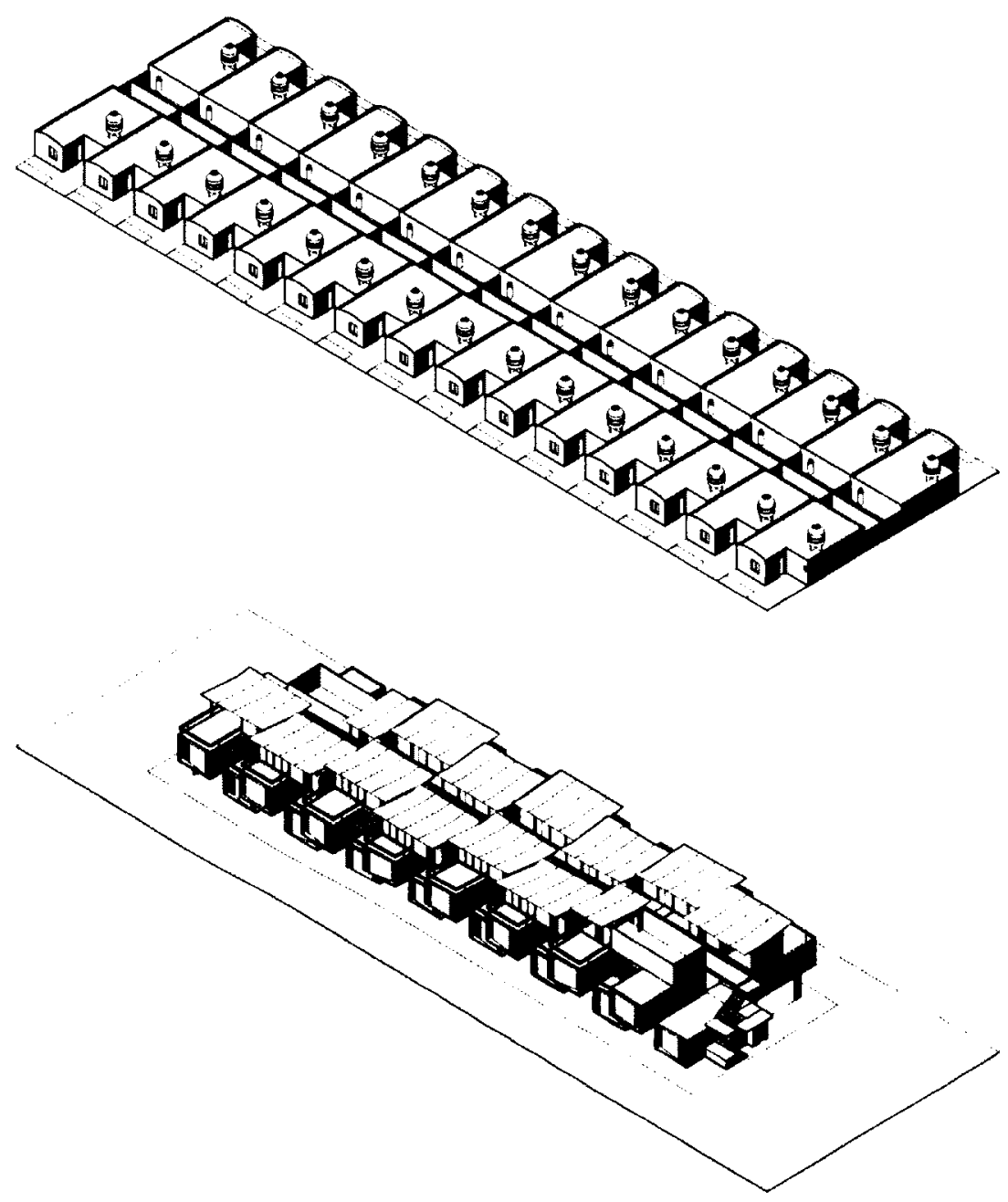

ALTERNATIVE TYPOLOGY 


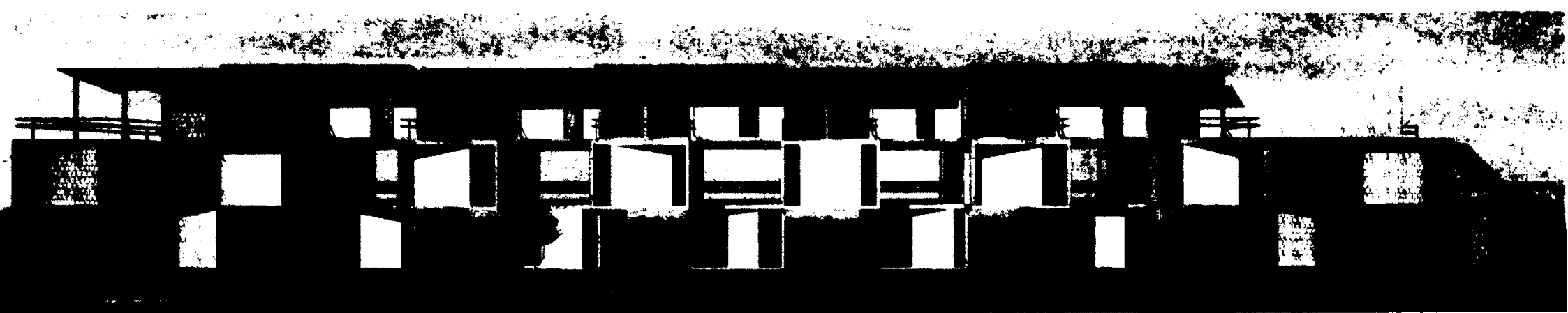

UPON CONSTRUCTION - EMPTY CANVAS

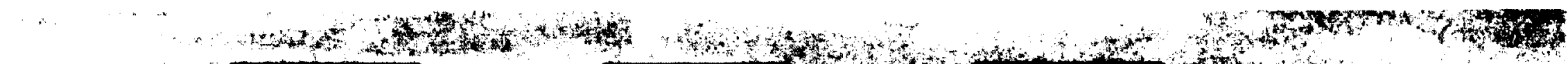

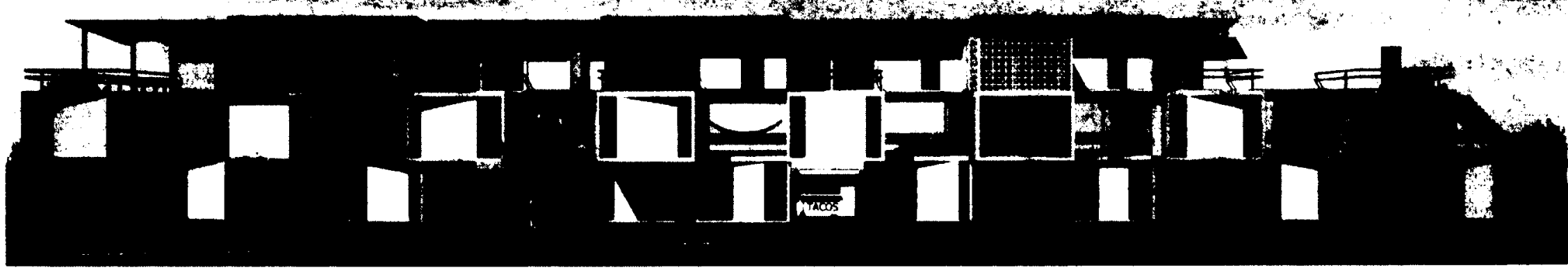

5 YEARS AFTER CONSTRUCTION

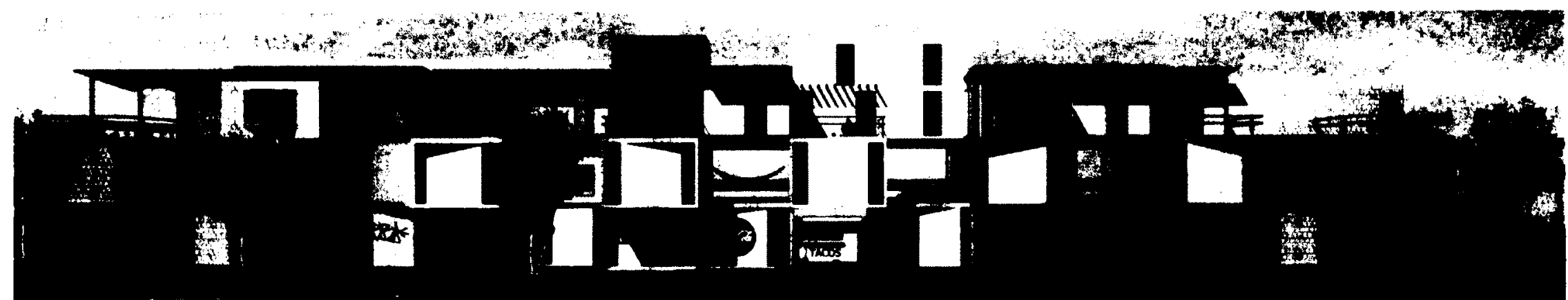

10 YEARS AFTER CONSTRUCTION 

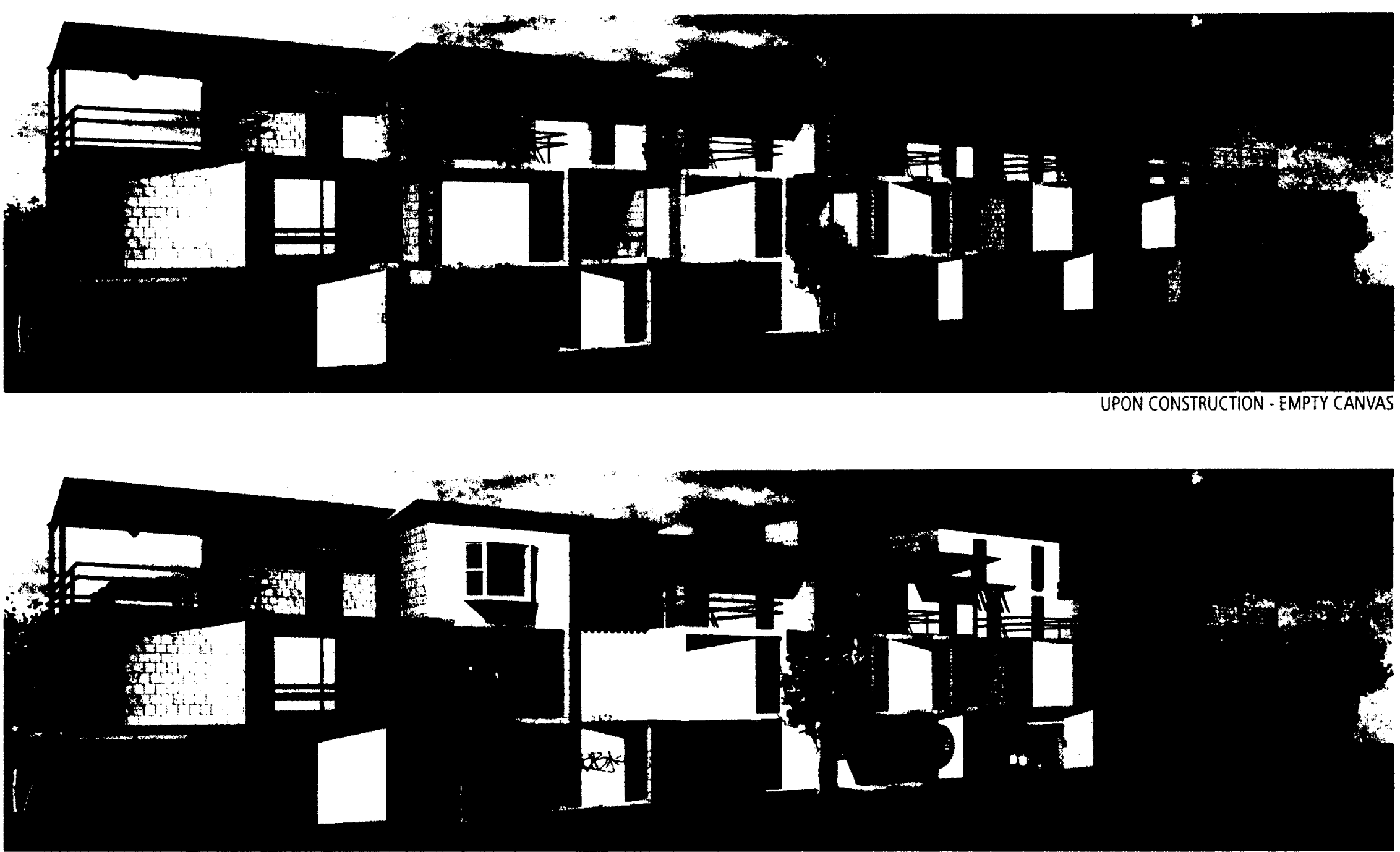
The Parachutists Alternative

WASTE MANAGEMENT

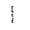

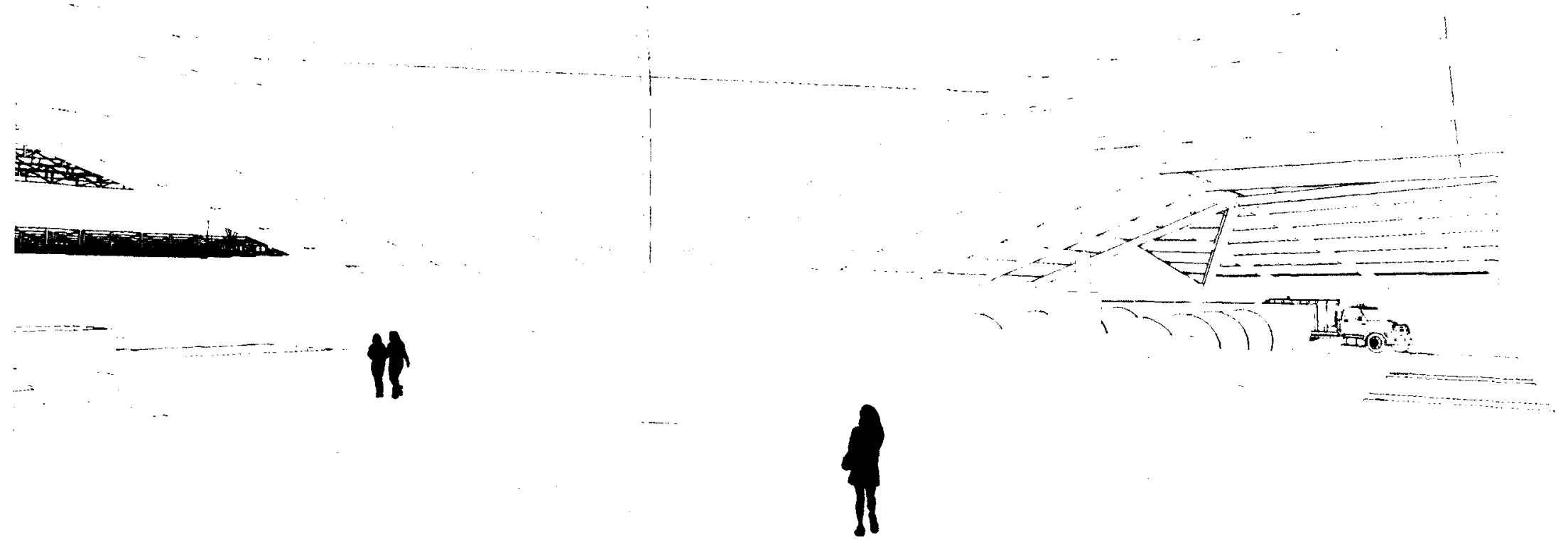

PAGE 81 


\section{WASTE MANAGEMENT}

A large portion of municipal waste handling in Mexico City is done by the informal sector, keeping costs and the state's responsability to a minimum. Cacique leaders usually mediate between the formal and informal sectors - controlling the dumpsites and the pepenadores (sorters) that work in them.

In 1992 pepenadores from the neighboring municipality Ciudad Nezahualcoyotl were relocated to the colonia La Loba in Chimalhuacan after the government decided to build a sports complex where they lived. Each family was given patches of land on which to build houses. For decades the pepenadores lived right on the dump in houses or shacks made of material found on the dump, mostly wood, plastic and cardboard. According to one of the inhabitants, when they arrived in Chimalhuacan there was nothing except grass and water. The ground was swampy since it was near the lake and because of the high level of salt in the water no trees grew there. ${ }^{01}$

The Tlatel Xochitenco dump, located immediately next to La Loba has been operating irregularly for over 30 years, in July 2010 the dump was closed after a methane explosion destroyed 11 homes and damaged over 400 others. ${ }^{02}$ However,

01. Frykman, Carina. The Power of Waste: A Study of Socio-Political Relations in Mexico City's Waste Management System. Rep. Print. P.13

02. "Milenio." ExplosiĀn En Basurero Abre Grieta Y DaÃta 400 Viviendas. Web. 31 Mar. 2012. <http:// www milenio. com/cdb/doc/noticias2011/7c954b2a681dd8c89db2c26caf4fbd85>.
The Parachutists Alternative since there was no alternative landfill in the municipality there are still people who continue to dump waste onto the site. Furthermore, over 270 pepenadores who were employed at dump lost their job upon the dump's closure. As Francisca Bolaños, a former pepenadora at the dump explained: "We need the dump, not to throw away our garbage, but because we live off of it, it is what we know how to do, we our waiting for the authorities to solve the problem so that we can work" ${ }^{03}$ The waste management aspect of this project proposes a new sorting facility on the site with recycling and composting centres. The proposal also calls for future wasteto-energy facilities on the site. The existing open air dump will be transformed into a new landfill that will have a housing project and large green areas for the settlement to enjoy. The sorting facility will also integrate community involvement spaces into and on top of its built structure, such as an outdoor theatre, a multipurpose sports stadium, a community library and rooftop garden areas.

Being a Pepenador implies serious health concerns. Life expectancy of a Mexico City dumpsite scavenger is 39 years, compared to 67 of the general population. ${ }^{04}$ The new proposal takes this into consideration and the new facilities will offer a much cleaner and healthier way to sort and recycle garbage, providing the pepenadores with a means of employment, while also offering a better quality of living.

03. "Milenio." Aä̊n Cerrado, Basurero Tlatel Xochitenco Sigue Generando Molestios. Web. 31 Mar. 2012 <http://edomex.milenio.com/cdb/doc/noticias2011/419fdc3369c49add19f8a4d915c1c697>.

04. Frykman. Op Cit. P. 21 
The Parachutists Alternative

WASTE MANAGEMENT CENTRE PROPOSAL - FLOORPLAN

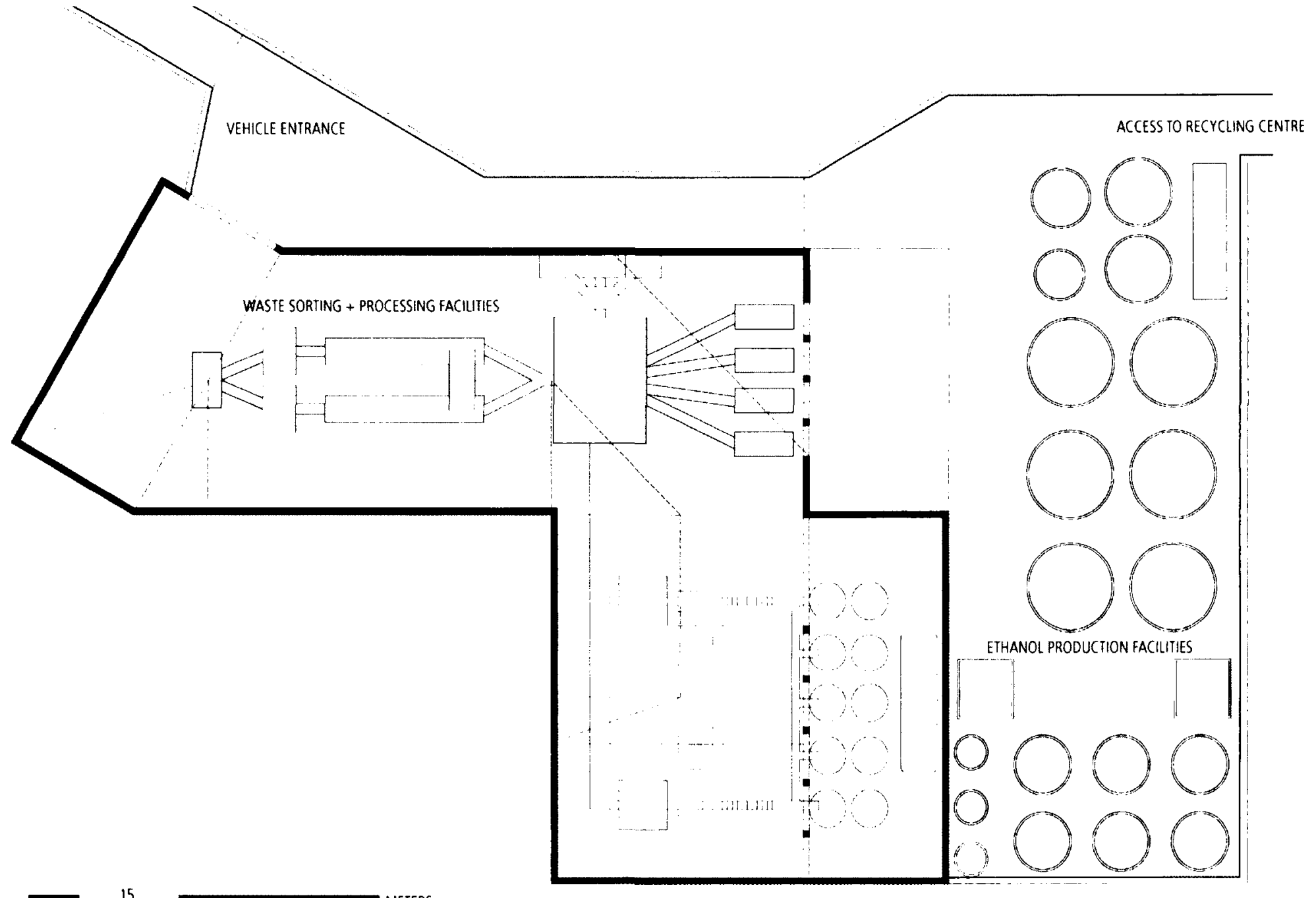


STANDS FOR PLAYS MOVIES AND SEMINARS

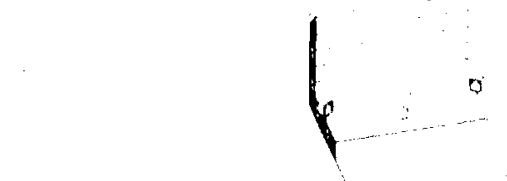

0

GREEN ROOF

STANDS FOR SPORTS
AND CONCERTS
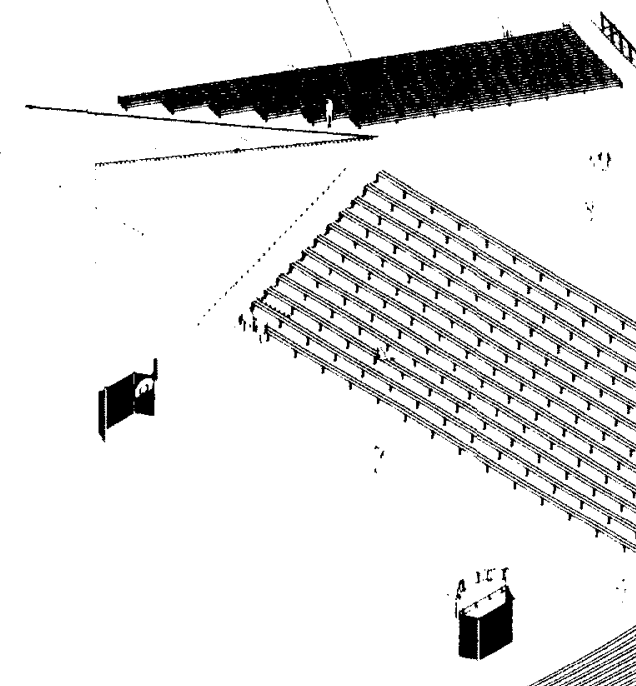

PUBLIC LIBRARY

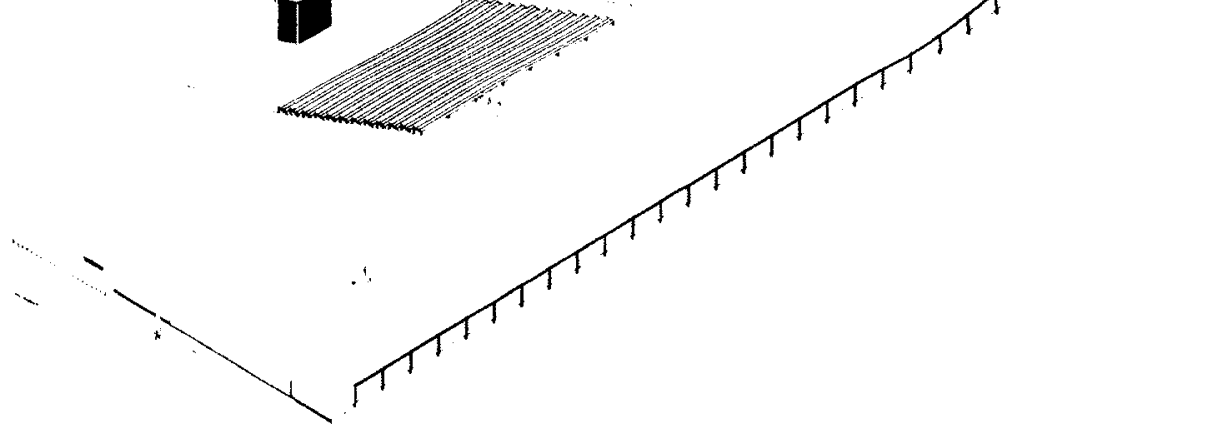

FUTURE GROWTH FOR WASTE TO ENERGY FACILITIES 


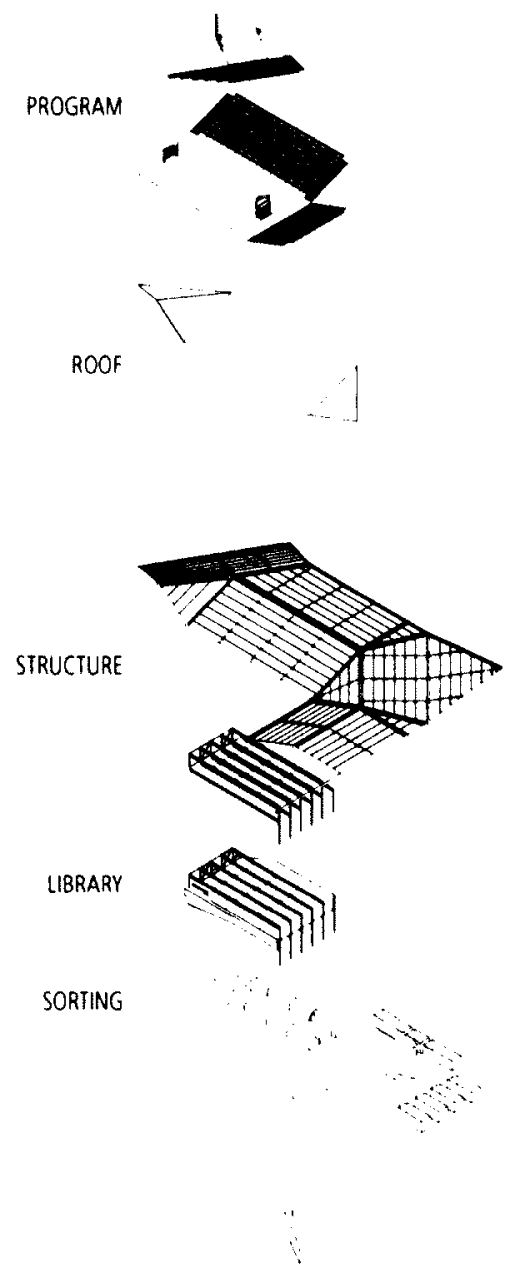

FOUNDATION

The foundation shall be set below grade in order that the roof programming (sports stands, library and theatre) can be accessed at grade level. 


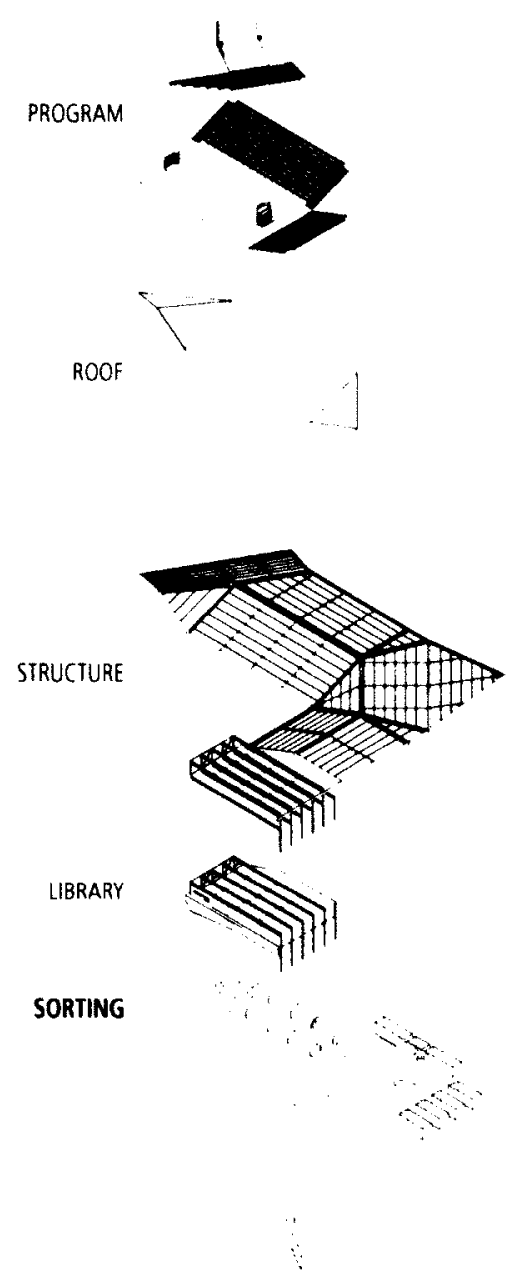

FOUNDATION
SORTING + WASTE TO ENERGY FACILITIES

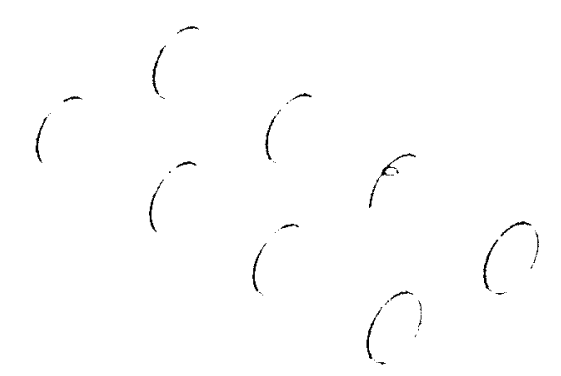

Sorting facilities will replace the existing open-air dump. By doing this, much of the existing waste that is now thrown away can be salvaged: such as recyclables that can be sold and reused, and organic waste that can be composted and used to improve Chimalhuacáns saline Soil. The sorting facility includes two waste processors that will reduce and sanitize the waste through thermal hydration steam treatement. The proposed facility can process 20 tons of Waste per hour, meaning that the 300 tons of waste that Chimalhuacán produces daily can be processed in 15 hours. 


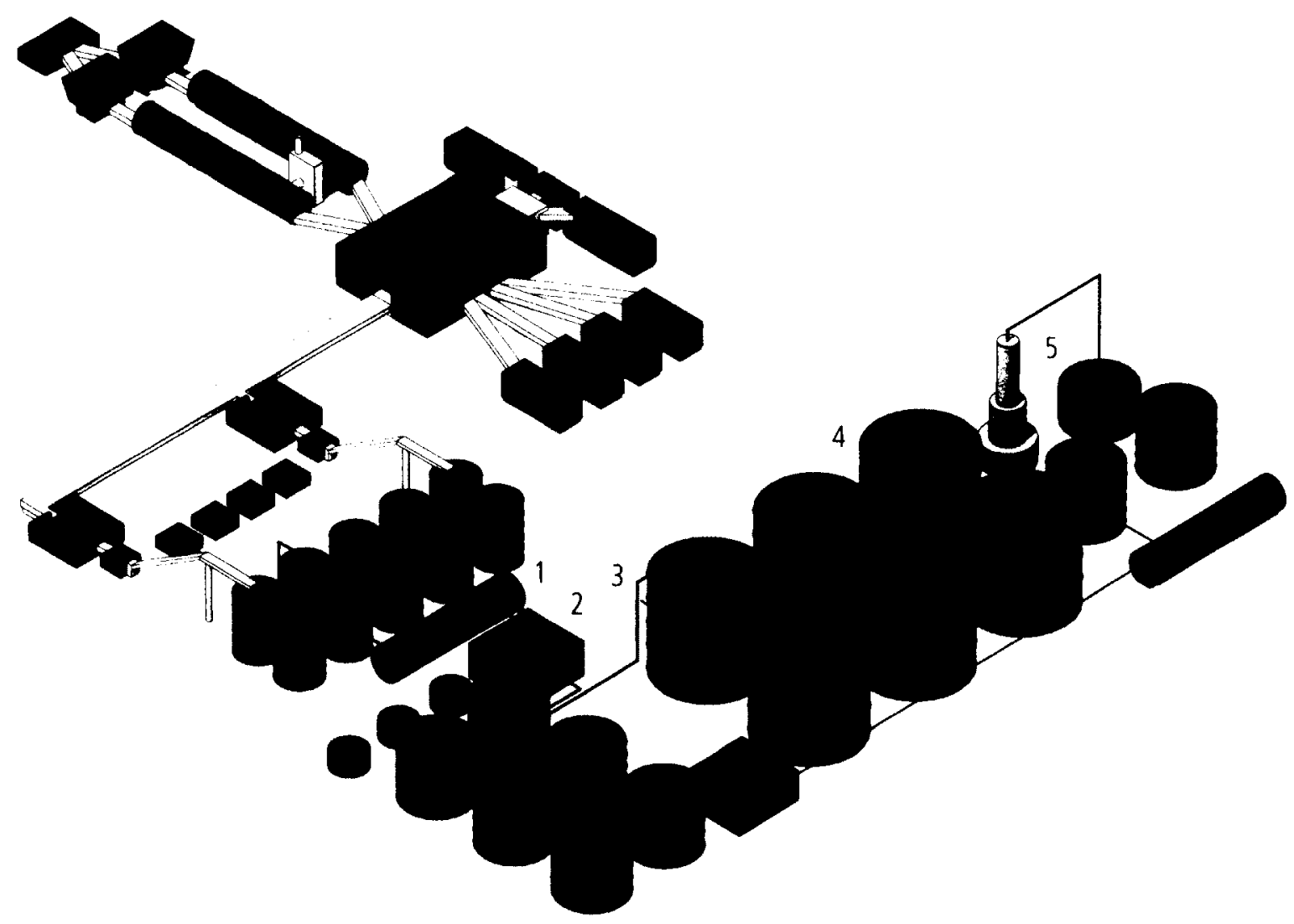

Pre-sorting and Loading

Shredding and Feed Hoppers

Vantage Waste Processor $\times 2$

Sorting (General)

Sorting (Plastic)

Material Storage

Storage Hopper

Acid Storage

Hydrolysis

Filtration

- Acid Recycling

CO2 Storage

Sugar Solution

Yeast

Fermentation

Centrifuge

Bio Ethanol $10 \%$

Distillation Chamber

Bio Ethanol $99.7 \%$

1 Lignum

2 Gypsum

$3 \mathrm{CO} 2$

4 Stillage

5 Bio Ethanol

The sorting facilities can be upgraded to include a Waste to Energy plant that can take the processed waste and turn it into highly valuable bio-ethanol or electricity which will be an income generator for the people of Chimalhuacán. In addition, the sorting plant will provide a healthier and safer employment option for the existing pepenadores of the open air dump. 
PROPOSED WASTE TO ENERGY CENTRE - EXPLODED VIEW OF SPACES
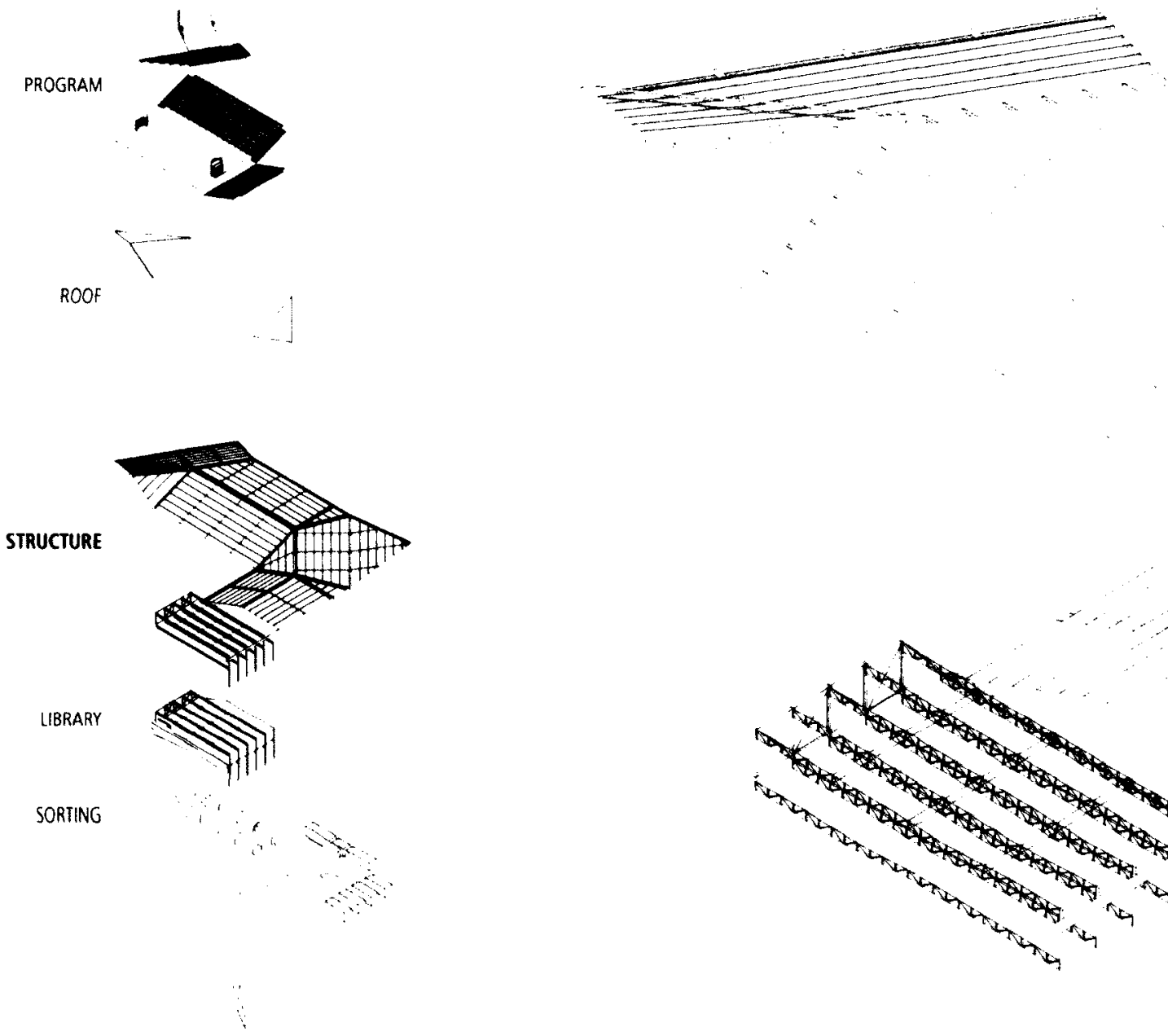

STRUCTURE

FOUNDATION

The facilities will need to have a strong steel-framed structure that is capable of supporting vertical loads and resisting seismic activity. The proposed structure will be supported on steel columns and on the reinforced concrete foundation walls. 


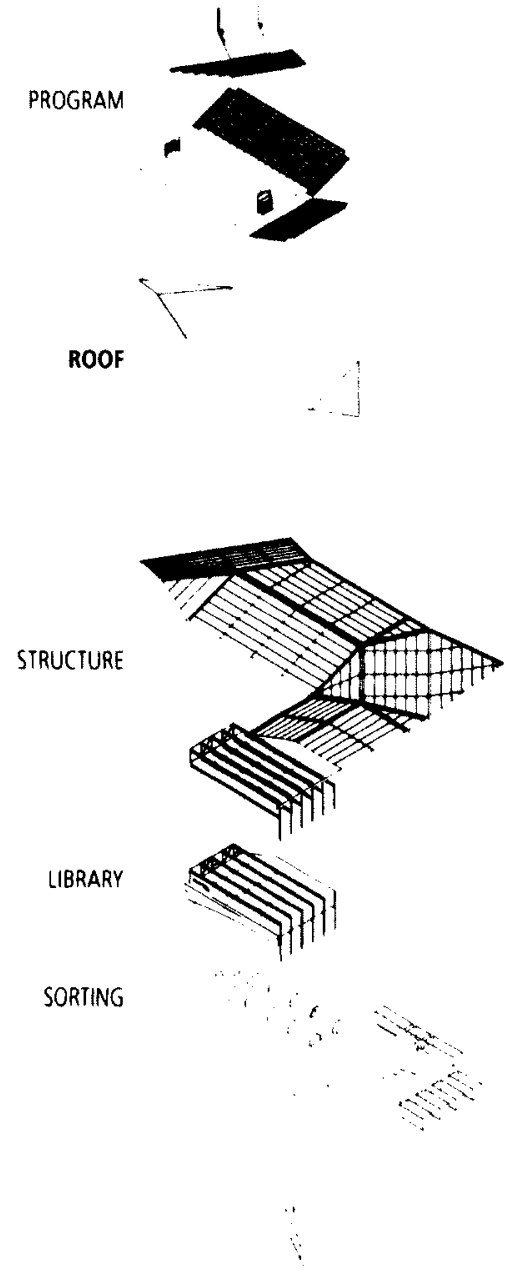

FOUNDATION
The concrete roof is designed with various inclinations in order to support stands for a sports field, an open-air theatre, to accomodate a library and to provide a lookout point in its highest corner. 


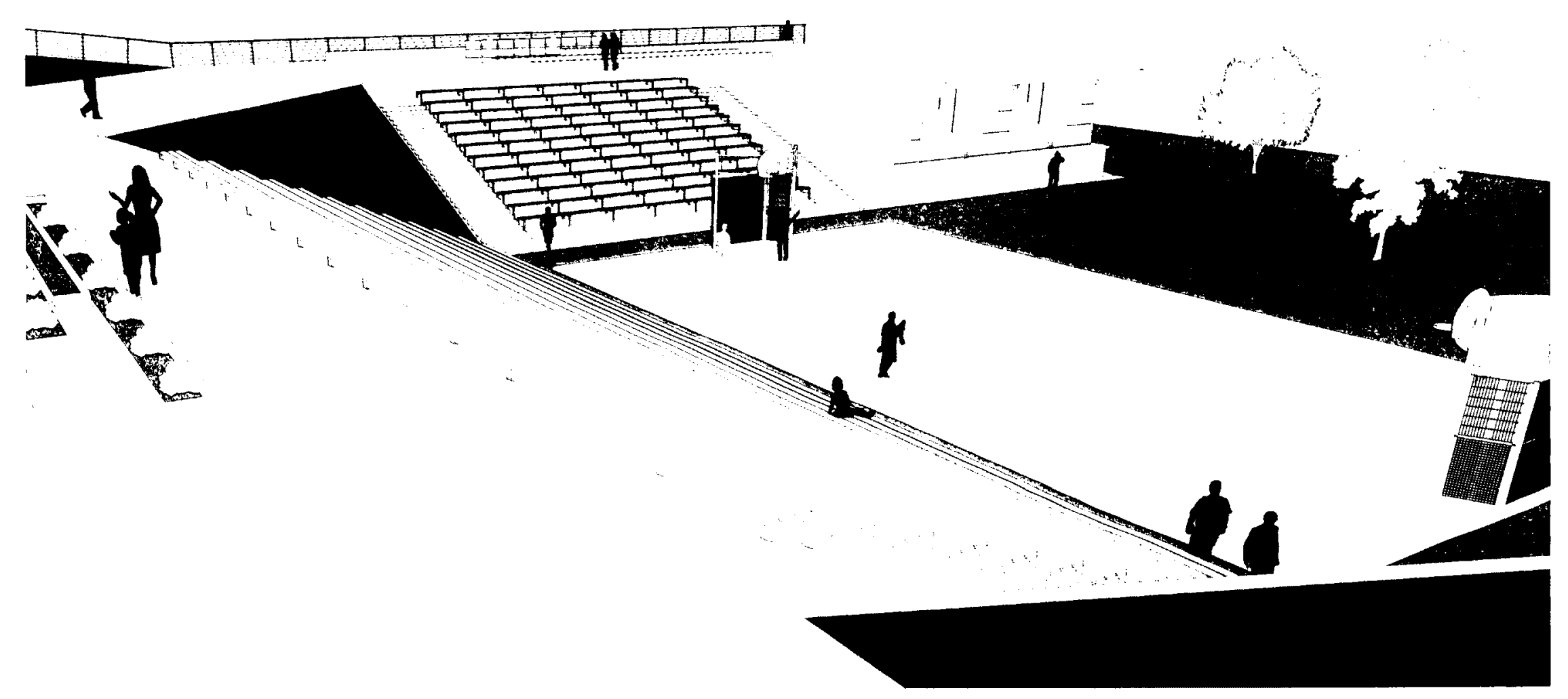




\section{COMMUNITY INVOLVEMENT SPACES}

Community involvement spaces can be vital places within informal settlements since they provide alternative recreational and learning opportunities, as well as a potential breeding ground for social organization.

Community involvement spaces are specifically important in communities such as Chimalhuacán - where a significant amount of people (mostly young) engage in activities such as drug-trafficking, youth gangs and social disorder. The lack of alternatives must be addressed through the development of new building types and spatial programs. These new programs certainly don't expect to end drug use or crime, but they can provide alternative activities where responsible entertainment and tolerance is reinforced. In the Santa Cruz slum in Caracas for example, the crime rate in the area decreased 30 percent since a vertical gymnasium designed by the 'Urban Think Tank' was opened in $2006 .{ }^{01}$

The proposed community involvement spaces in Chimalhuacán are integrated directly into the waste treatment facilities in order to maximize the building's productivity, reduce overall construction and maintenance costs, and provide more public green areas by minimizing the overall building footprint. The proposed spaces include a community library that can be accessed by the general public in order to read, learn and access the internet; a multi-purpose sports field and stadium that will be used for sporting events and concerts; a rooftop garden for planting herbs and produce; and an open-air theatre for plays, public seminars, community organizing and movie-nights. 
CASE STUDIES
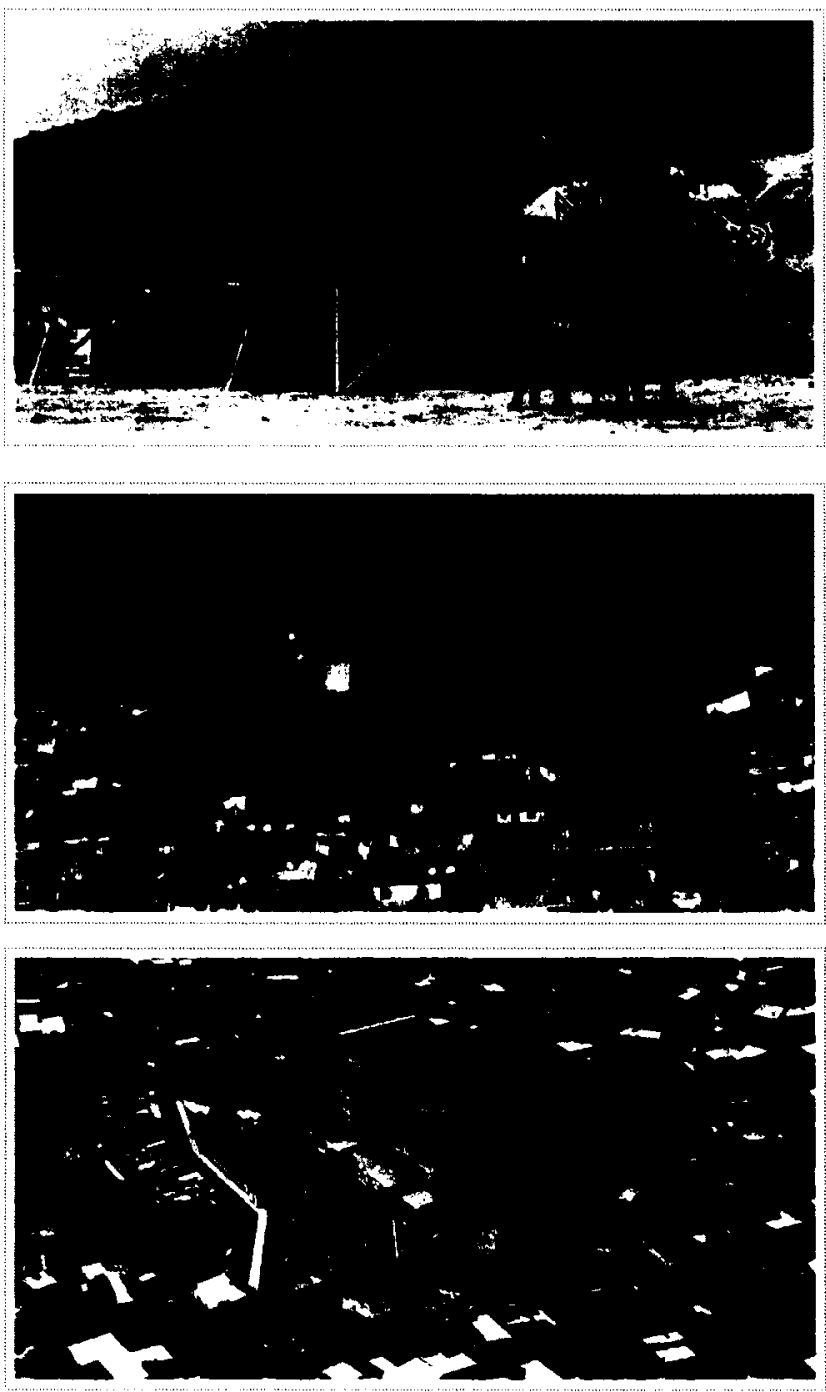

FARO DEL ORIENTE, MEXICO D.F

Taller Alberto Kalach

FARO is a Cultural centre located in Iztapalapa, a low-income, ammenity deprived municipality of Mexico City. There are currently over 800 students enrolled in the arts and crafts workshops and over 50,000 people attend FARO events annually. The building houses a school of a school of arts and crafts, studios, a gallery for established international artists as well as local producers, a library and performance spaces for dance, music and theatre.

\section{PARQUE ESPAÑA LIBRARY, MEDELLIN} Giancarlo Mazzanti

The Project is noticeable from a big part of the city, allowing it to redefine itself as the symbol of a new Medellin, as a way of making people feel identified and receiving the building as their own. The program has a library, a training section, administration room and auditorium. There is also a large viewing platform that empowers the building as a meeting point, multiplying the connections and letting it develop as an urban reference.

\section{GROTAO COMMUNITY CENTRE, SAO PAULO}

Urban Think Tank

In the Grotao Community Center and Park, the priority is equipping this peripheral neighborhood with infrastructure, water, sewage networks, lighting, services, and public space. The proposed urban model aims to translate a society's need for equal access to housing, employment, technology, services, education, and resources - fundamental rights for all city dwellers-into spatial solutions 


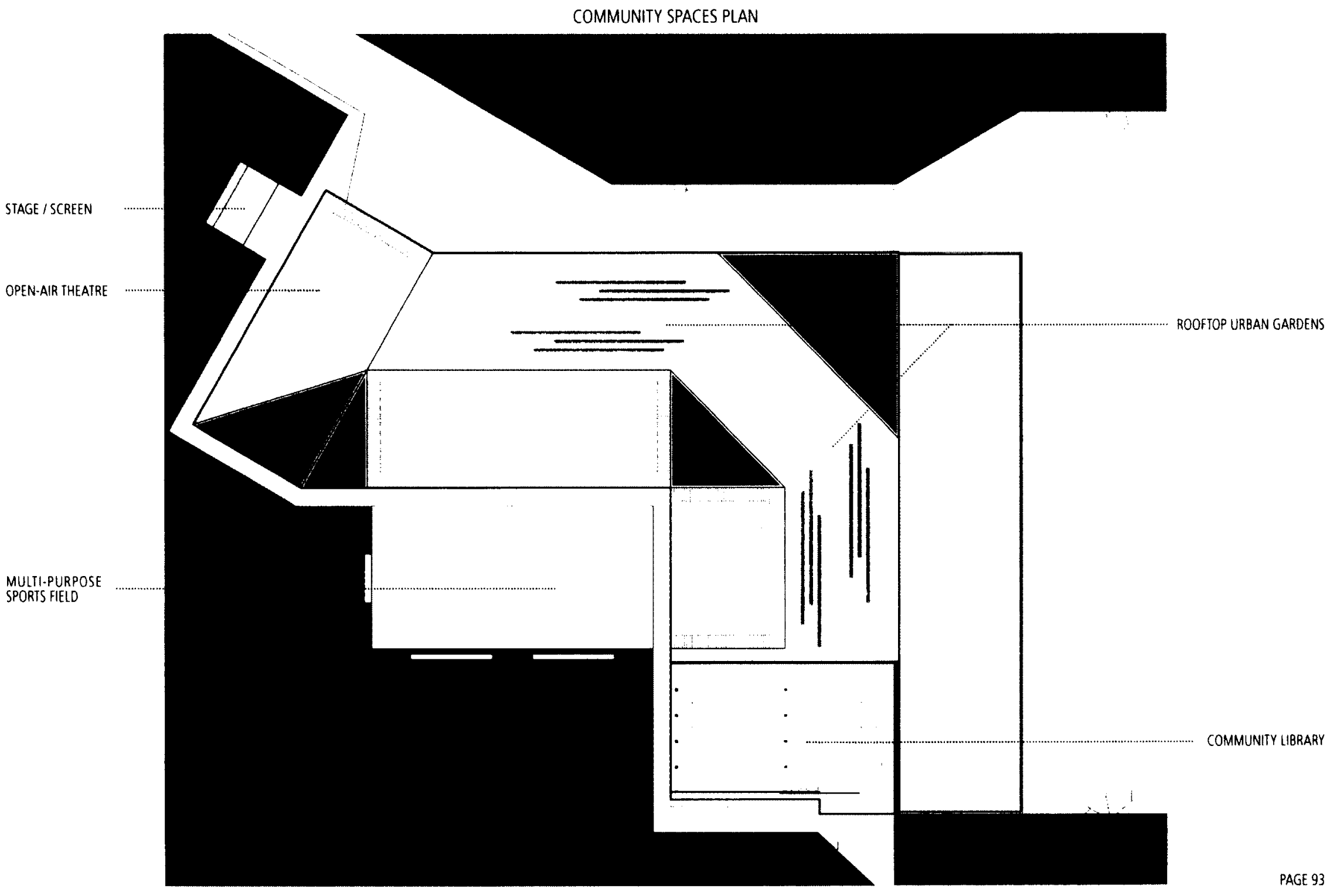




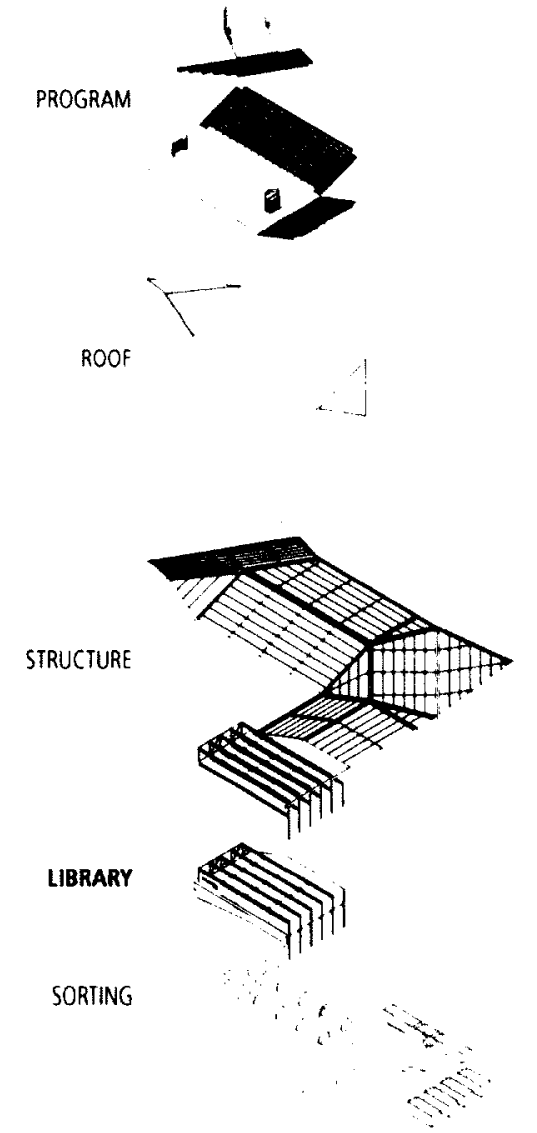

FOUNDATION
LIBRARY

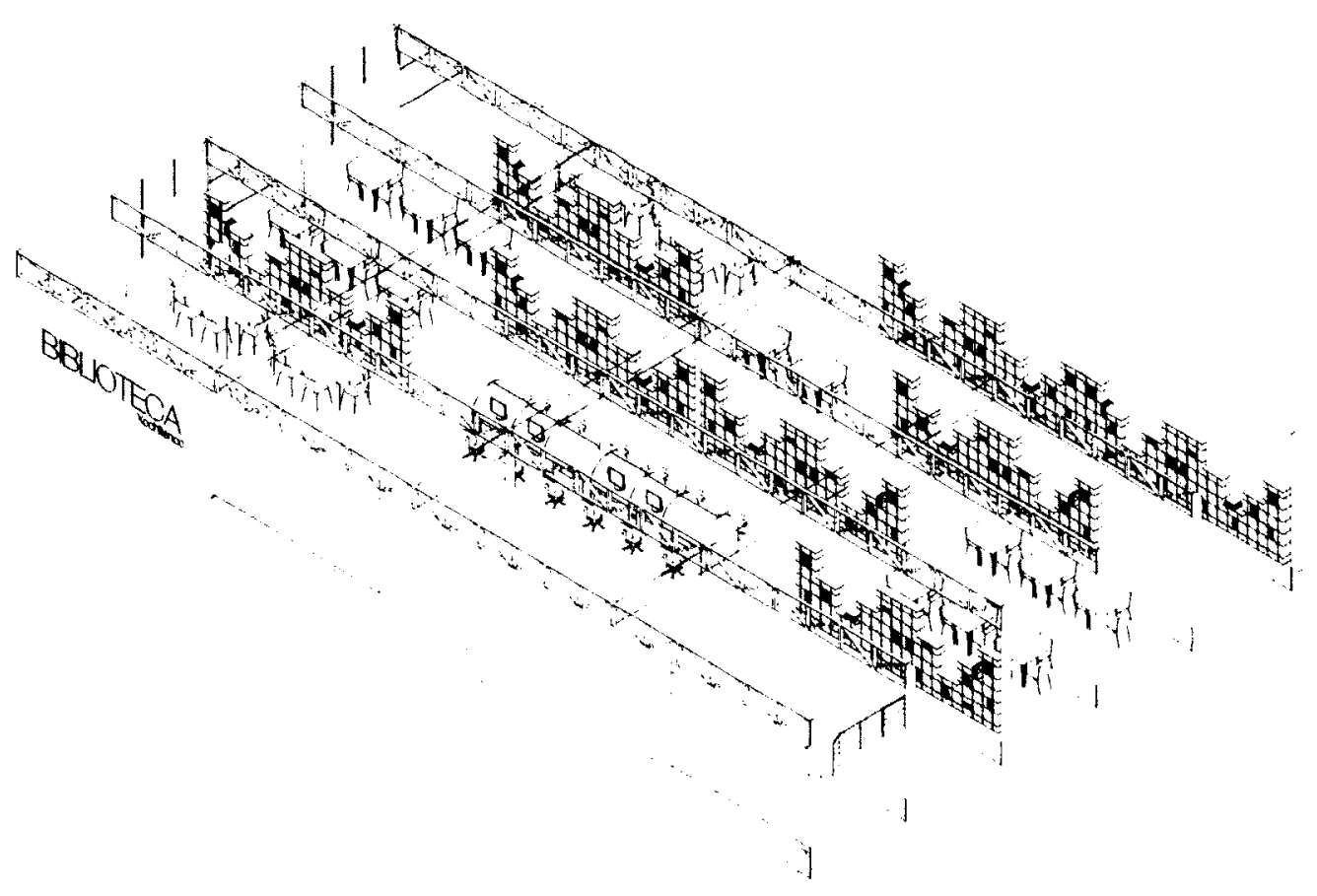

The library will offer access to the internet and reading material for educational and recreational purposes. 
PROPOSED WASTE TO ENERGY CENTRE - EXPLODED VIEW OF SPACES

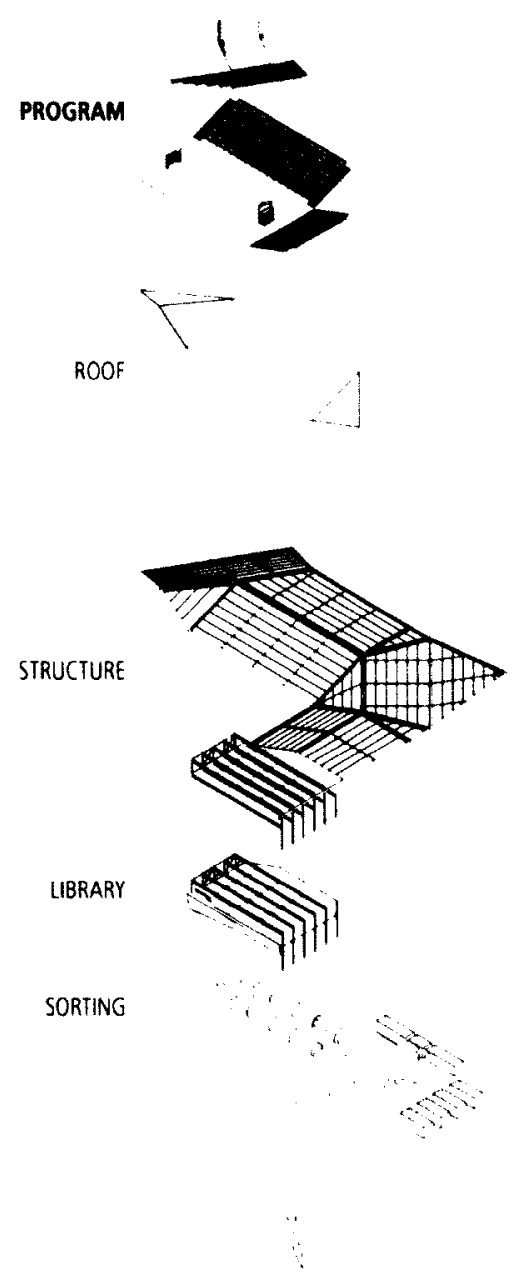

FOUNDATION
The Parachutists Alternative

PROGRAM

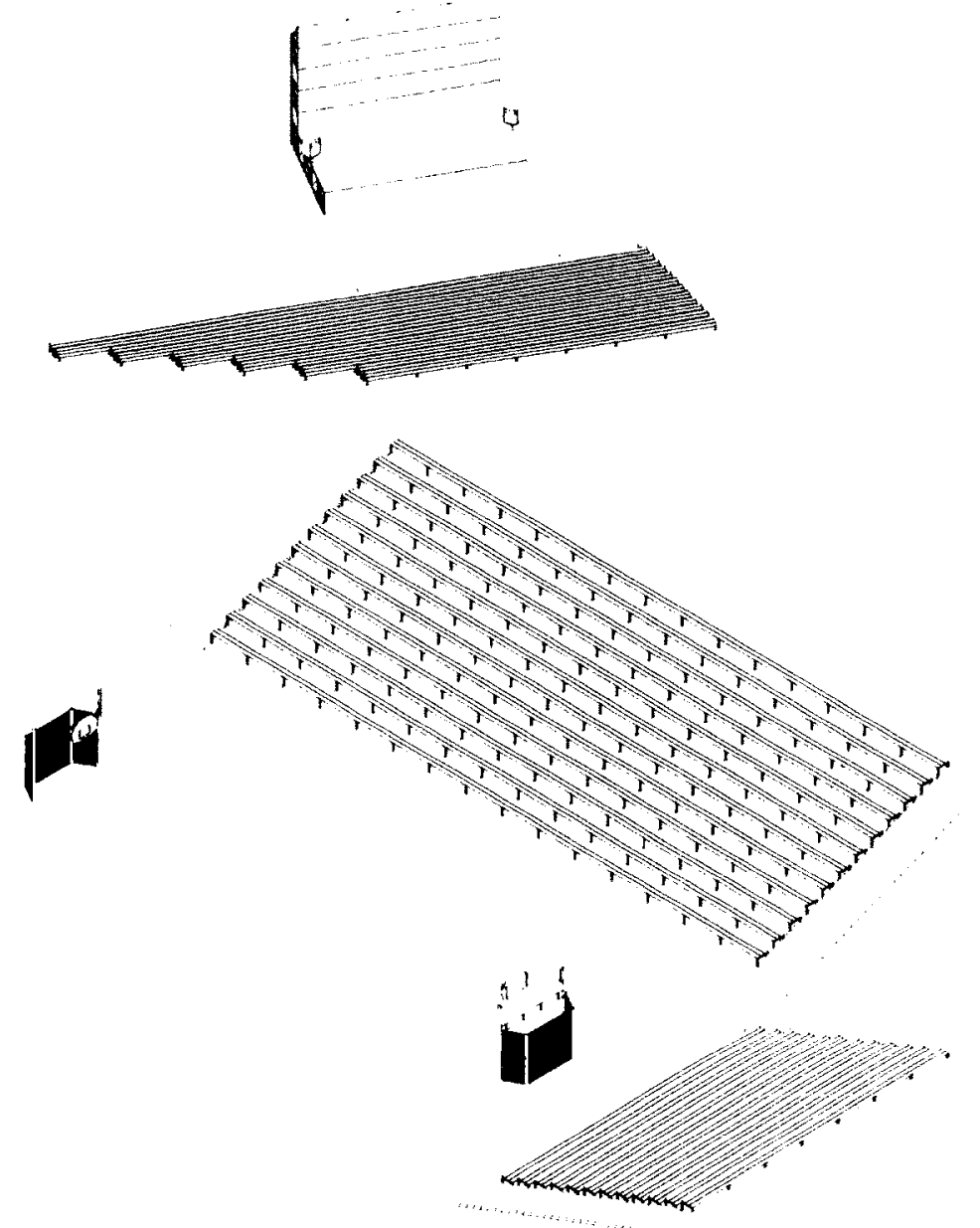

The roof of the sorting plant will be used to accomodate special programming such as stands for sports events and concerts; an outdoor theatre for plays, seminars and movie nights; and a community garden area. 

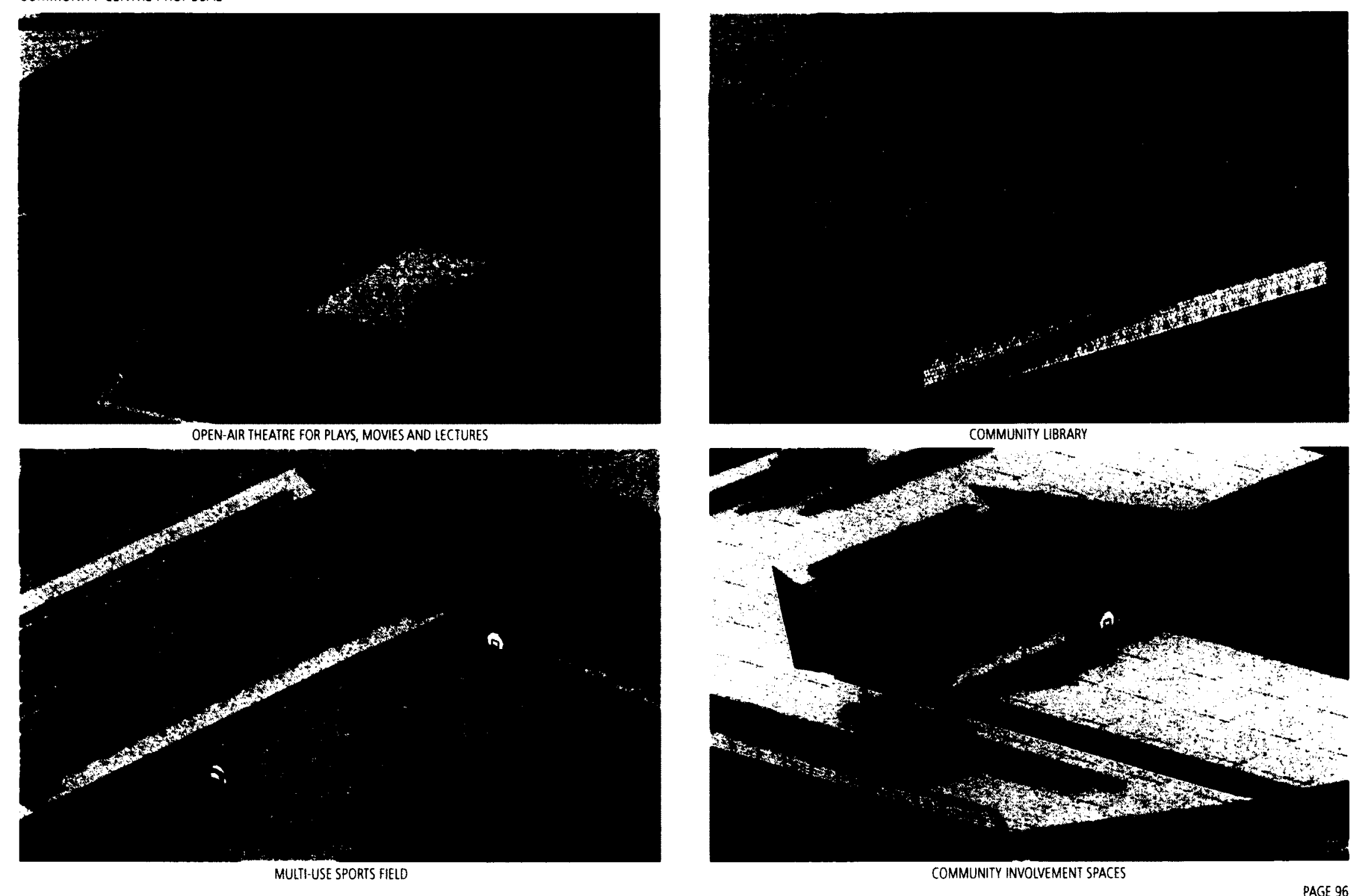


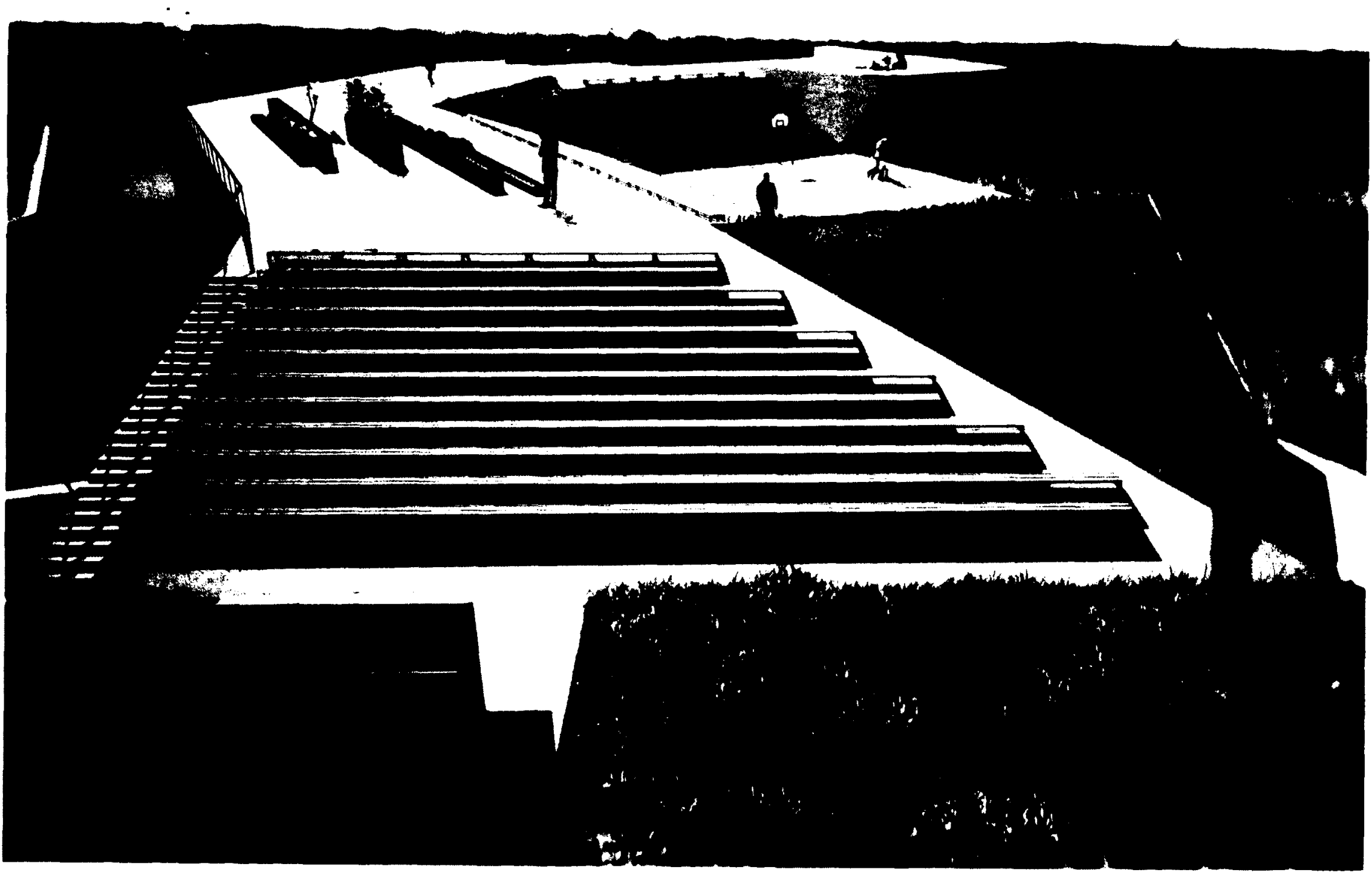




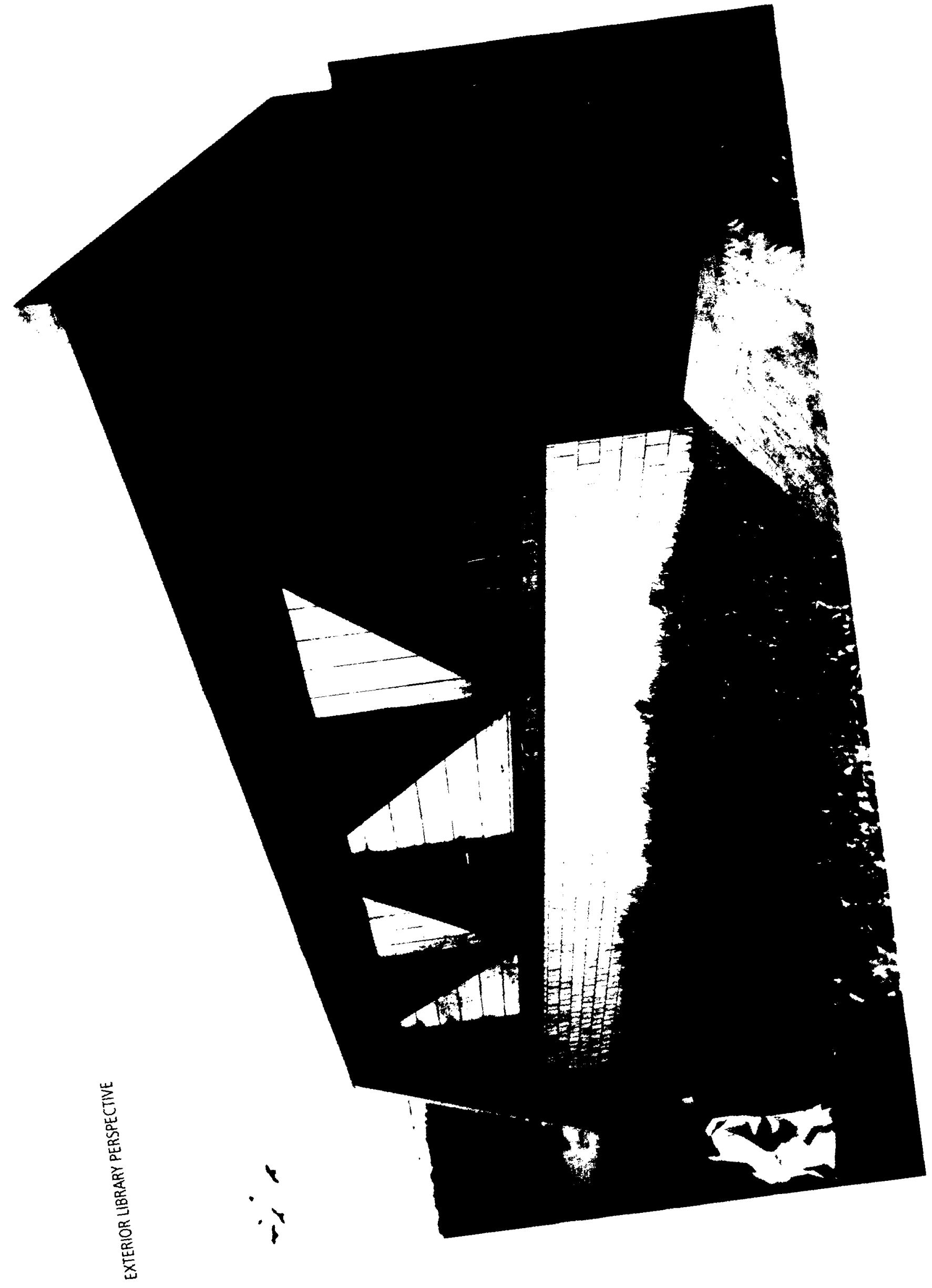




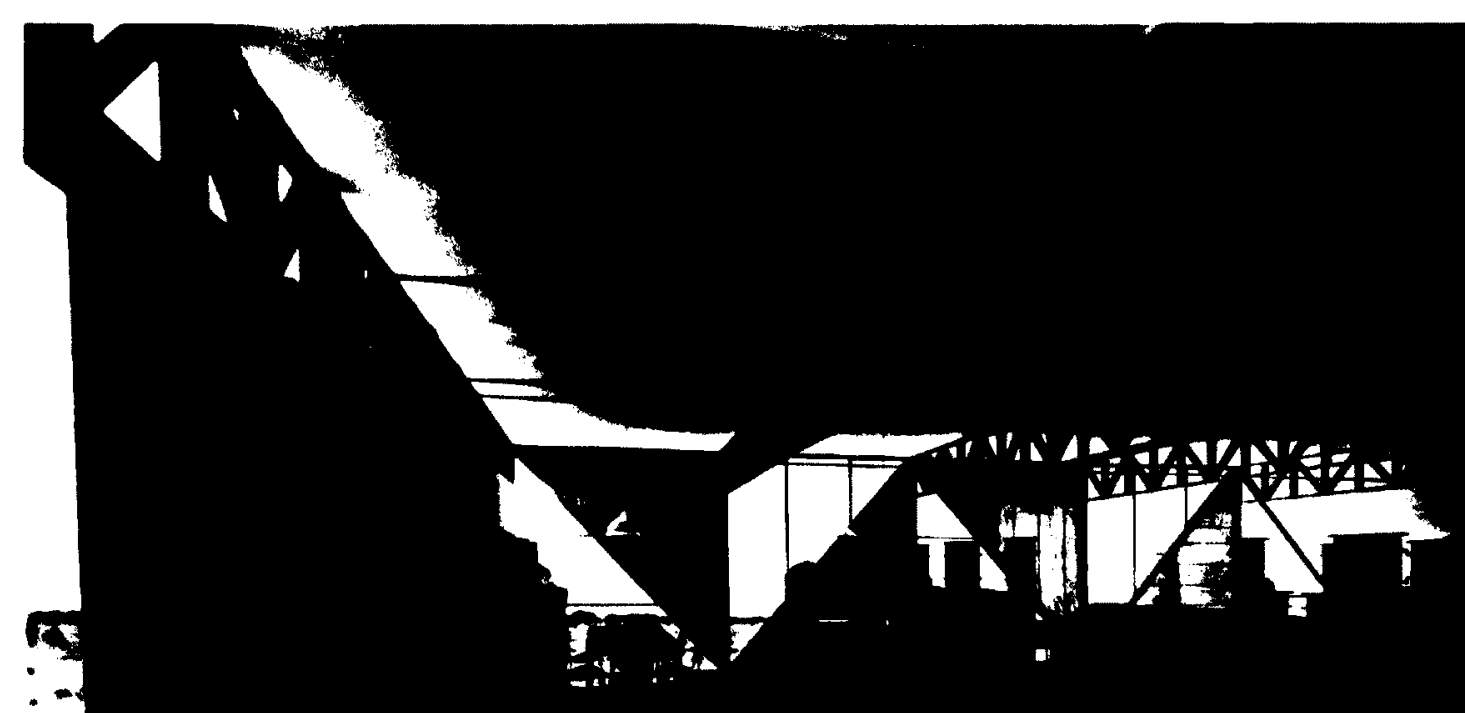




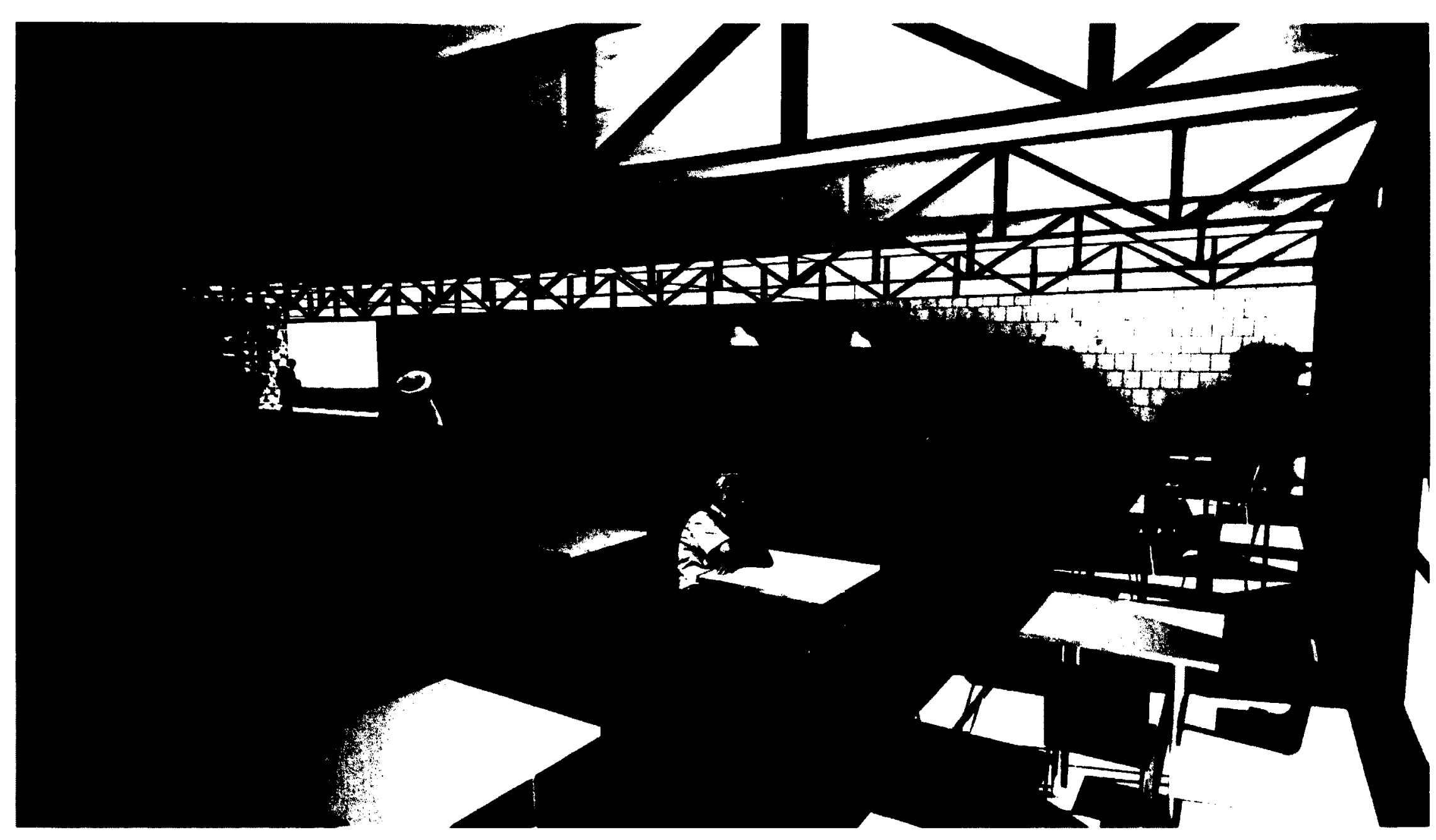


TIANGUIS / INFORMAL MARKET

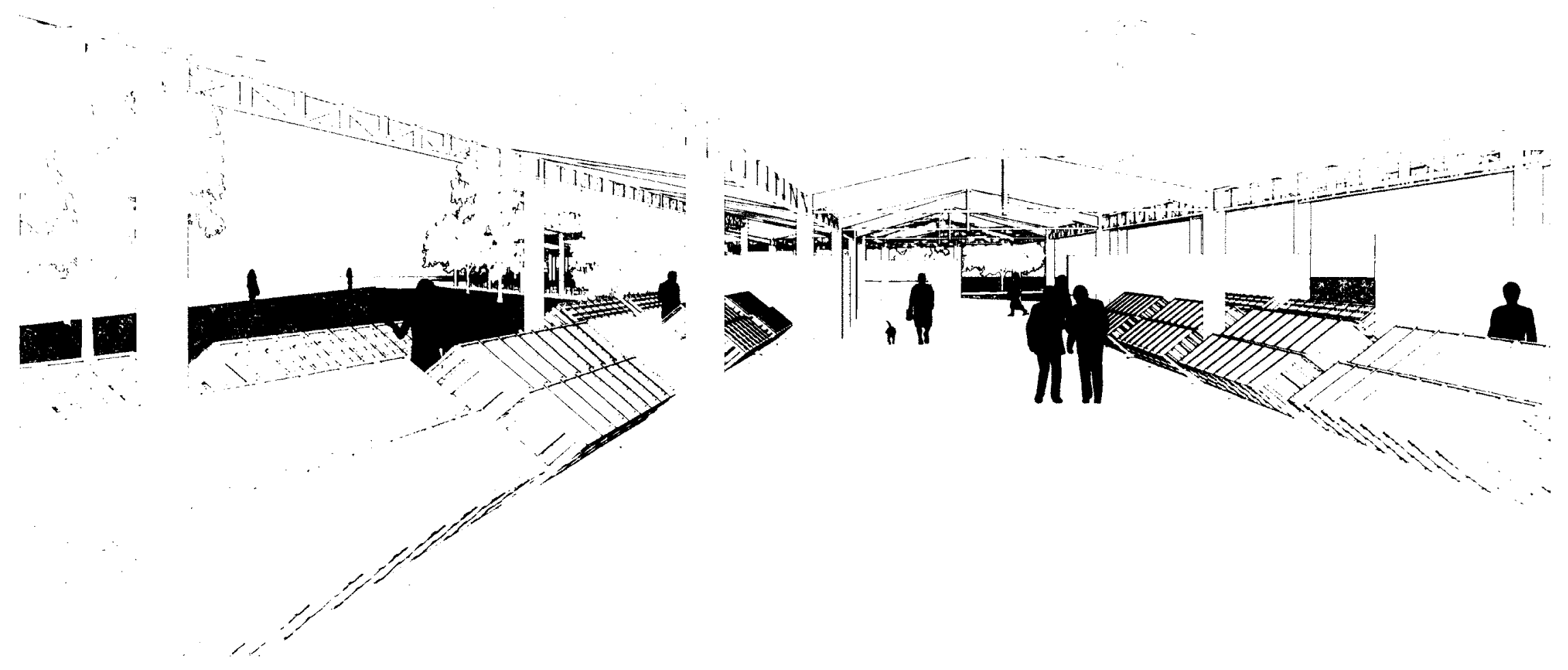


TIANGUIS / INFORMAL MARKET

Recently the Tianguis (informal market) Las Torres, which had settled informally for over 25 years on "Las Torres" Avenue, was evicted. Since the $80^{\prime}$ 's this market had taken over the main avenue under the control of the local mafia that would charge over 300 tianguistas between 30 and 80 pesos a day for the right to sell their merchandise.

The new tianguis proposal will be located on a plot of land that is currently vacant and next to the proposed extension of "Las Torres" Avenue. The new market will have a secure roof structure, green spaces, and exclusive areas for different types of commerce and services (food, clothes, crafts, etc...)

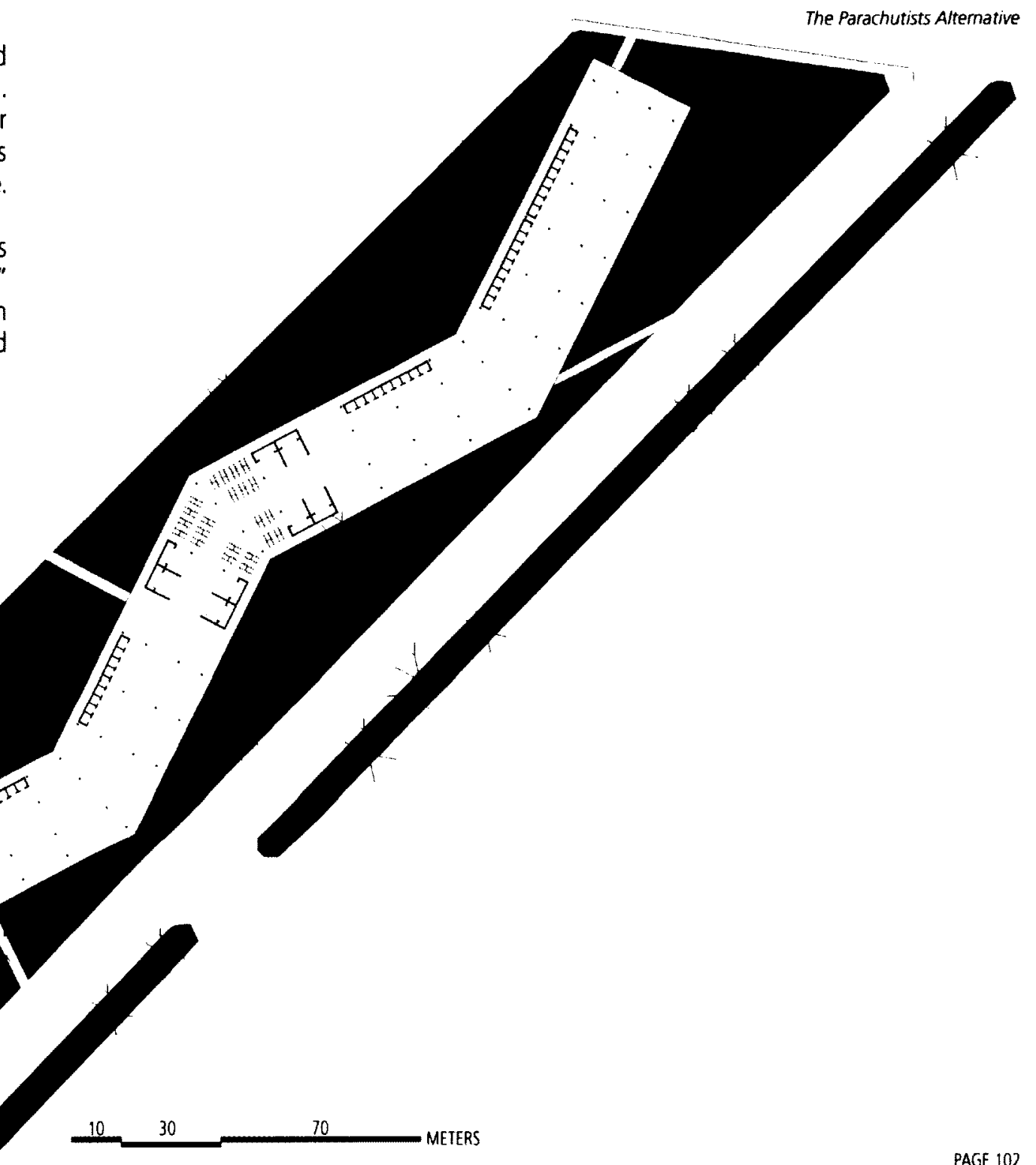


EXPLODED ISOMETRIC VIEW-TIANGUIS

The Parachutists Alternative

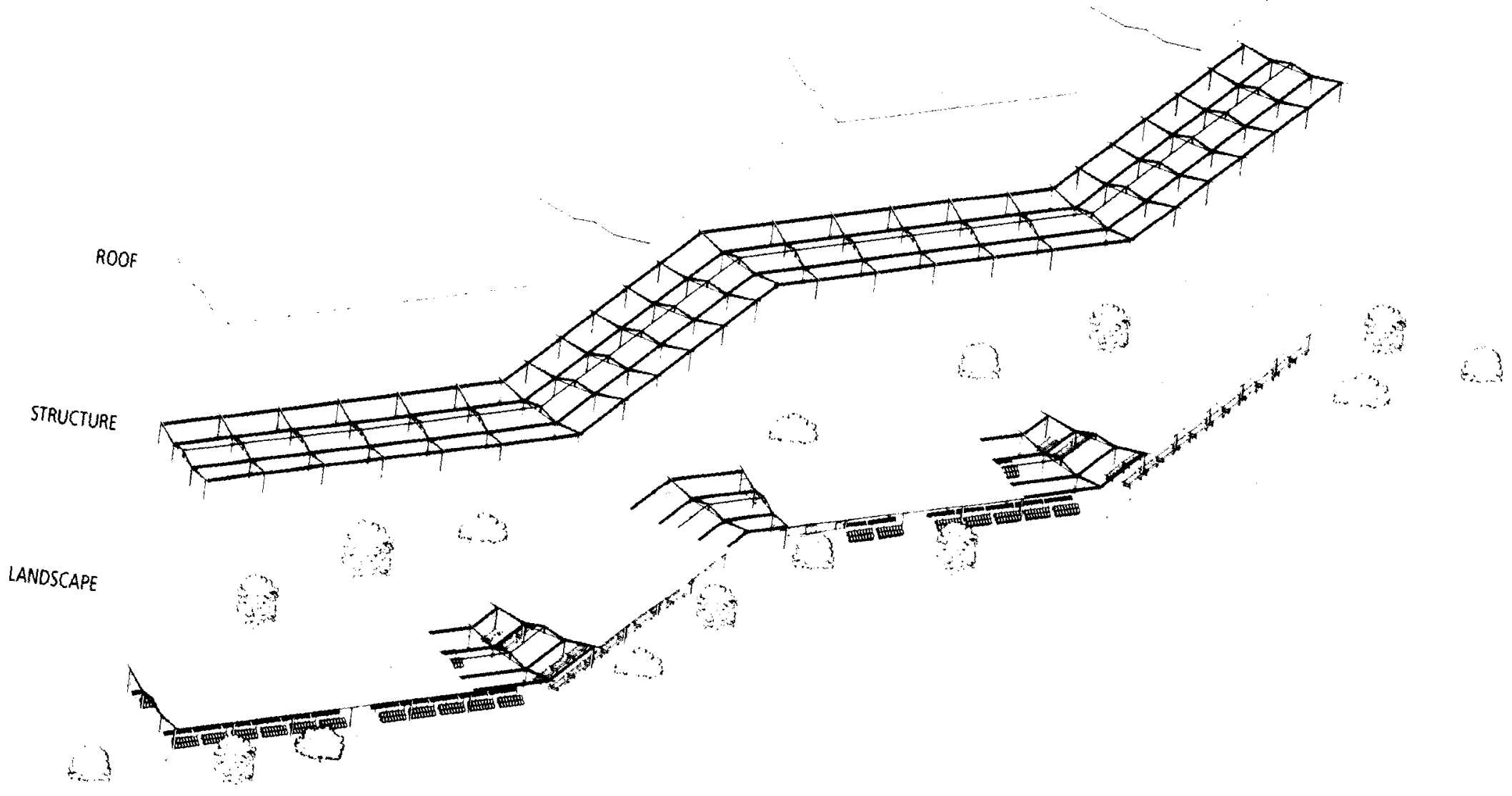




\section{TRANSPORTATION}

Squatters usually settle towards the margins of a city in order to pass unnoticed by authorities and society. However, most squatters have formal or informal jobs within the city and need to spend hours commuting from their settlements to the city center. An effective slum intervention can't be effective if the issue of public transportation isn't appropriately addressed. Buses tend to be the most effective form of public transportation because the investment required per passenger is minimal.
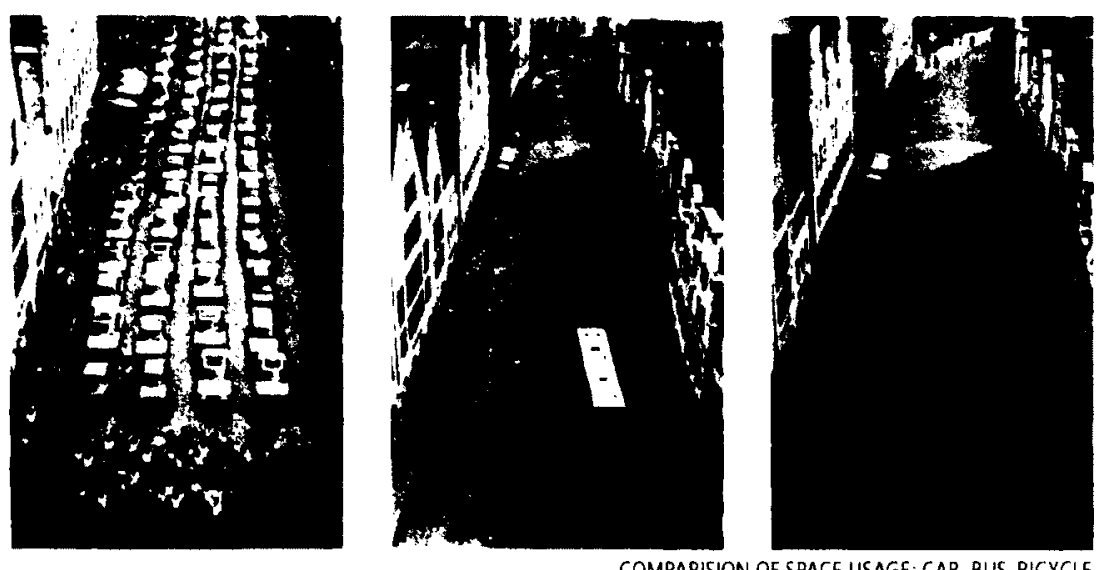

COMPARISION OF SPACE USAGE: CAR, BUS, BICYCLE

The Chimalhuacan project proposes an exclusive bus lane that will be connected to the Mexico City subway system. This will provide rapid and dependable connectivity to the rest of the city. In addition some of the existing dirt roads will be transformed into exclusive pedestrian and cyclist roads with extensive vegetation. Pedestrians, cyclists and public transportation will take priority in Chimalhuacan since most of the citizens depend on these ways of transportation as opposed to vehicles.

CASE STUDIES

\section{CICLOVIAS BOGOTA}

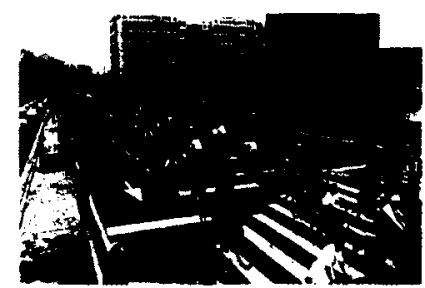

METROCABLE CARACAS/MEDELLIN
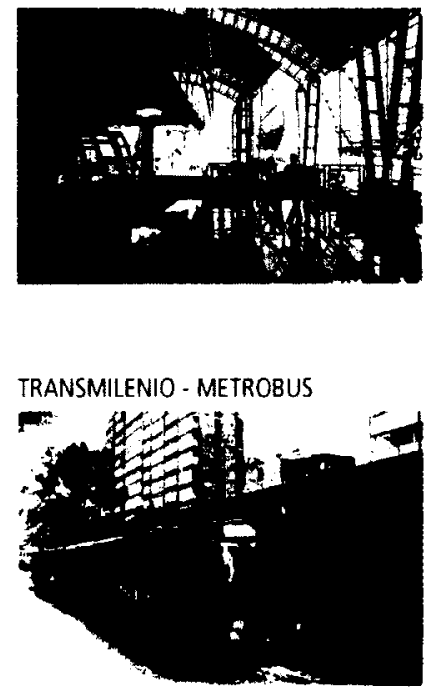

The Colombian government has invested in exclusive bicycle lanes that provide greater mobility, decongest motor traffic, and improve air quality. Every Sunday, major traffic lanes are closed to motorists and openened to pedestrians and cyclists.

The cable car system, which is integrated with the Metro System of Caracas, is $2.1 \mathrm{~km}$ in length and employs gondolas holding 8 passengers each. Metro Cable's capacity allows for the movement of 1,200 people per hour in each direction.

Bus Rapid Transit (BRT) is a transportation system that creates bus lines in exclusive lanes that are faster and more efficient than regular buses. The goal of these systems is to emulate the quality of rail transit, without the associated costs. 
PUBLIC TRANSPORTATION PROPOSAL

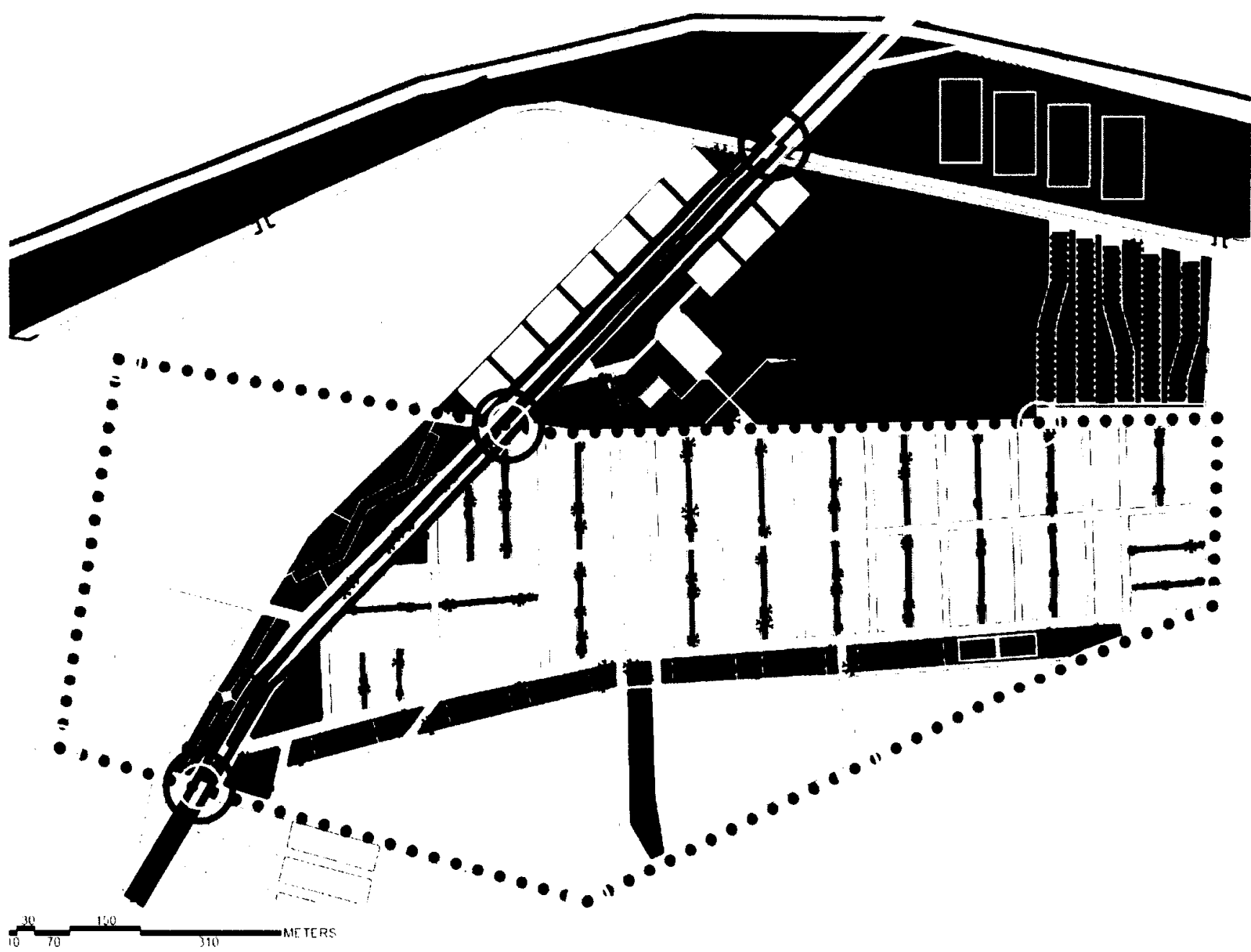

PROPOSED BUS LINE - LINKED TO SUBWAY STATION

$\bullet \bullet \bullet \bullet \bullet \bullet \bullet \bullet \bullet$ COLONIA MICRO-BUS ROUTE

Bus station (MANOR)

BUS STOP (MINOR) 

The Parachutists Alternative
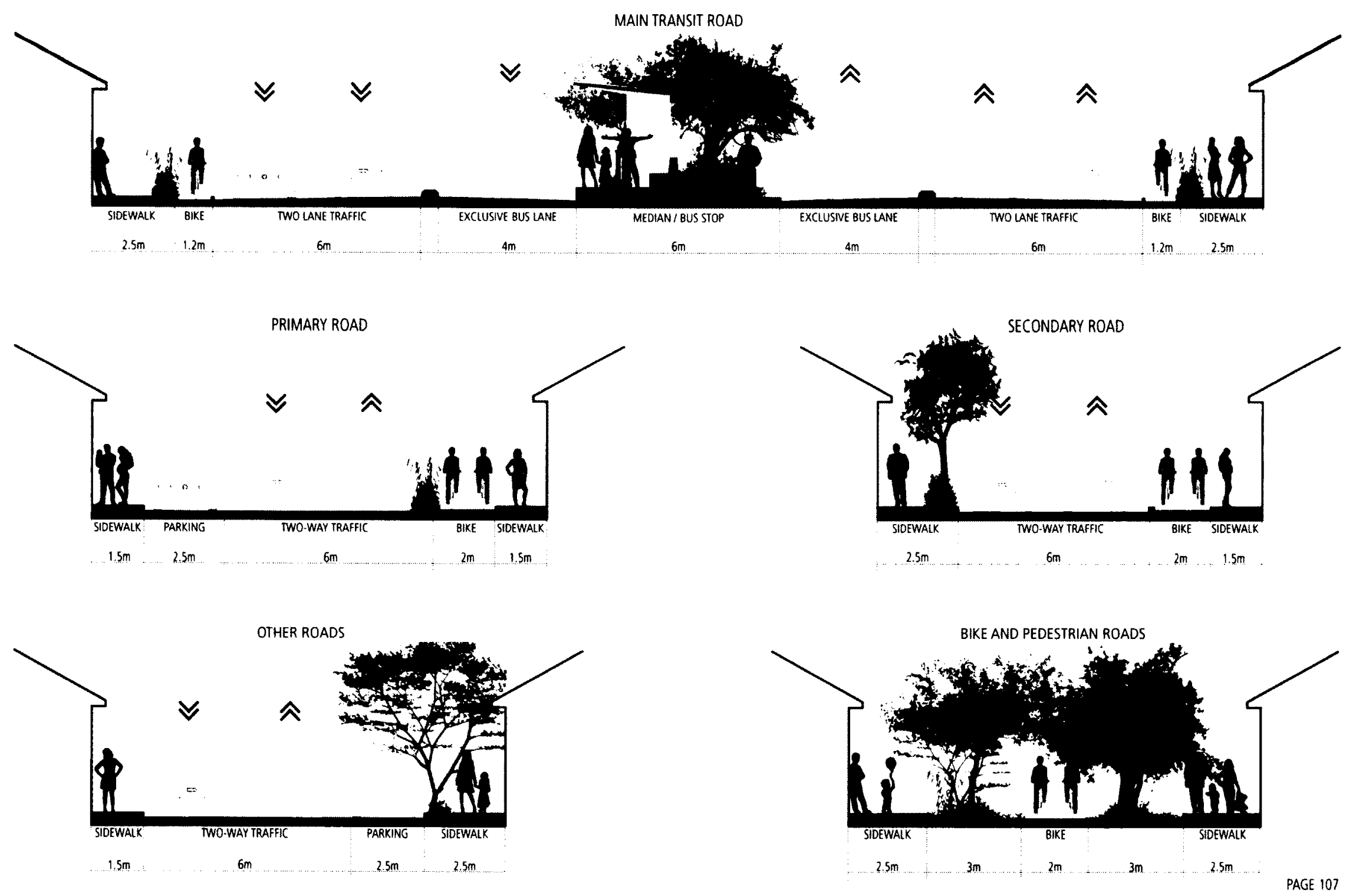


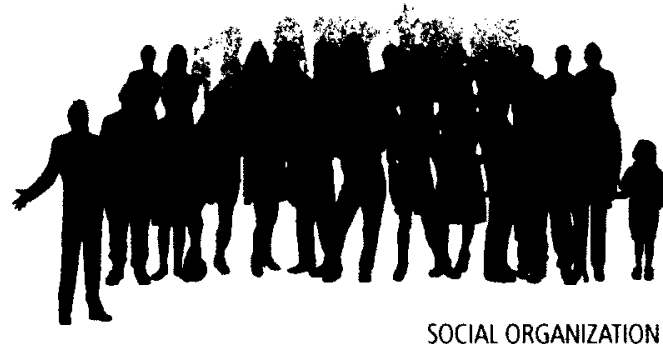

Parachutists are strong as a collective. All over the world, informal settlers have been able to use their collective voice and political clout to advocate better living conditions and services for their settlements. Social organization is essential in order to create a consensus and effectively negotiate new services, infrastructure and micro-financing with the government.

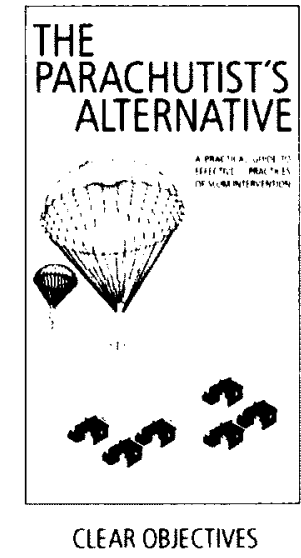

It is important that the parachutists have clear objectives regarding what they need and how to get it done. By doing this, parachutists can more effectively negotiate with government officials, and a clear project will also limit the opportunity for corruption throughout the process. The parachutist's alternative provides examples of some projects and other grassroots projects can be developed with help from NGO's, universities and professionals.

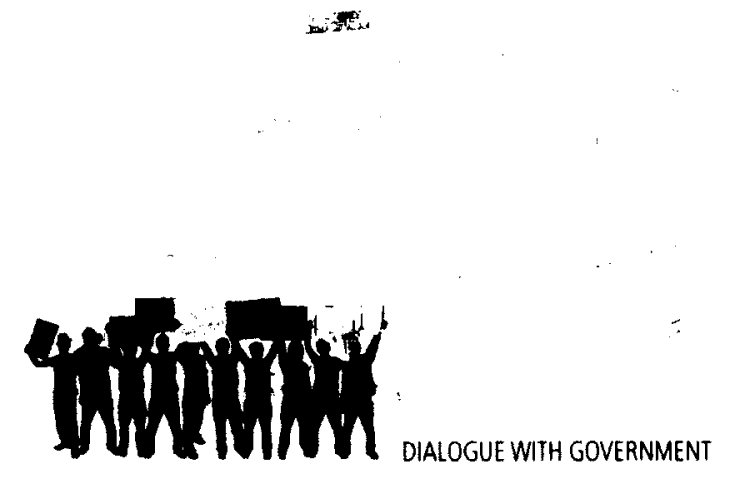

Once there is social organization and a clear project objective, community organizers can meet with government officials to express their needs and formalize a petition. When government officials are reluctant to engage in a dialogue, methods such as a planton (occupy protest) can be used to gain attention. This common method has been very effective in the past within Mexico City in order to obtain government funds for low-income settlements. 
As the world's population has grown and its disparities become more evident, the need for social architecture in the emergent cities of the global south has become greater and more pressing. Even throughout the duration of this thesis development, the prominence of the issue of social and economic inequality dramatically increased as the world fixated its attention on the cumulative polarization of social classes resulting in world-wide protest movements such as occupy Wall Street. Though such protests are an important reflection of a global situation, how much more urgent and contrasting must the issue of social inequality be in the global south, where informal settlers are more preoccupied trying to survive than to participate in public demonstrations?

This thesis attempts to address some of the issues regarding the role of the architect in the global south - a role that has diminished considerably since the collapse of Modernism when architects set out to provide housing for the masses. However, upon reflection, the research possibly raises more questions than it set out to answer - can professionals really have a positive impact in an informal settlement? Are the proposed projects feasible in a society that is plagued by corruption? Can an urban acupuncture approach, such as the transformation of the dump site in Chimalhuacan, really produce a positive ripple throughout the entire community? And will the interventions be appropriated or rejected by the informal settlers? Such contingencies are difficult to evaluate or anticipate, and any architectural intervention in an informal settlement will quite likely be affected by such unforeseen factors. However, social architecture projects shouldn't seek to create an ideal situation - they should be about preventing catastrophes and hopefully, about empowering slum-dwellers to improve their unfortunate predicament.

There is a stark polarization between opposing positions regarding the issue of informal settlements. There are those who romanticise squatter settlements by praising their ingenious and resilient ability to overcome adverse situations, and those who demonise the settlements as being pestilent, dirty and parasitic. In the professional field there are those who believe architects can positively act as agents of change within urban slums, and those who believe slum-dwellers should be left alone to build their cities in order to avoid a potential re-colonisation by external do-gooders. Whatever the position, this is a debate architects should be critically engaged in because the future of developing cities is deeply invested in the decisions and approaches that are presently being taken (or not taken). 
During the defence of this thesis, a question regarding whether or not a more aggressive, bottom-up position that defied the controlled social housing projects of the past would be a more worthy and suitable position to take. Though I believe such an argument has its merits, and it would certainly be a more idealistic and amorous approach, the real problems of third-world urban growth are not going to be solved by working within limited boundaries of a polarized spectrum. The utopic, visionary projects of modernism failed in part because they were overly concerned about the 'machine' and not the individual. Likewise, small-scale and individualistic grassroots projects that are organically developed will likely be unsuccessful if they can't be incorporated into a larger, urban situation that is under economic, environmental and social strains.

My position, and the position argued in this thesis, is that architects can potentially use their ability to identify, synthesize and elucidate complex issues to orchestrate an effective response to the difficult situation encountered in third-world slums. This approach isn't about philanthropy. It is about the possibility to redefine design and implement it in an expanded field where both the squatter and the designer can benefit from socially responsible architectural interventions. Though architects cannot single-handily change the economic system that is causing poverty, there is plenty of opportunity to imagine scenarios, explore alternative methods and practical approaches that could improve the living conditions encountered in slums.

The project component of this thesis - The Parachutist's Alternative - is a tentative exploration into some of these alternative methods and approaches. It is about creating new building models that combine formal and informal methods of development in order to satisfy a slum's need for basic infrastructure and services, while retaining the positive aspects of slums such as their spirit of collaboration and their ingenuity in the use of space - aspects that are commonly lost upon top-down governmental intervention. The project is an introductory model that addresses a small portion of the issues encountered in slums such as inadequate housing, insufficient green public space, unsustainable waste management methods and lack of community involvement spaces. The potential for future projects within informal settlements are infinite. As architects we have the opportunity to act as mediators between the conflicting formal and informal mindsets, empowering informal settlers to democratically define their own communities. 


\section{IMAGES, PICTURES, MAPS AND PLANS REFERENCES}

1. Squatter Settlement, Metro Manila - Neal Oshima 2006

http://wuw.urbanlandscape.org.uk/nealo/squatter00.htm

\section{TABLE OF CONTENTS}

2. Informal Shack, Cabo Polonio, Uruguay - Vava Ribeiro http://tmagazine.blogs.nytimes.com/2011/10/11/utopia-in-motion/

AVANT PROPOS

3. Colima Earthquake 2003 - Colimano

http://www.flickr.com/photos/colimano/4152646897/sizes/z/in/set-72157622920471340/

4. Social Disparity in Paraisopolis, Brasil - Urban Age

http://urban-age.net/10_cities/08_saoPaulo/_essays/SA_Caldeira.html

5. The Parachutist's Alternative - Dustin Unrau 2012

\section{INTRODUCTION}

6. Informal Settlement, Kibera, Nairobi - Sabrina Henry

http://sabrinahenry.com/2010/01/28/kibera-life-in-the-slums/

7. Favela, Rio de Janeiro - N. Cabana

http://www.travel-images.com/photo-brazil150.html

8. Mbare Township before and after Operation Murambatsvina, Zimababwe

http://thebeardedman.blogspot.ca/2005/06/magnified-pictures-of-mbare-zimbabwe.html

9. Rochinha Favela, Rio de Janeiro - Unknown Source

http://emergenturbanism.com/2008/11/06/design-configuration-and-natural-form

10. Slum in Haiti - Alice Smeets

http://www.spiegel.de/international/world/0,1518,597510,00.html

\section{SQUATTERS IN CONTEXT}

11. Caracas Urban Fabric - Eduardo Kairuz

http://post-traumaticurbanism.com/?p=257

12. Kibera Nairobi - Christy Gillmore

http://advocacynet.org/wordpress-mu/cgillmore/tag/kibera/

13. Sultanbeyli Istanbul - Unknown Source

http://www.flickr.com/photos/question_everything/3653990731/

14. Mumbai Slum - Joel Newell

http://stateofthenation.ca/?p=428

15. Pueblo Joven, Lima, Peru - Unknown Source

http://laformamodernaenlatinoamerica.blogspot.ca/2010/06/el-boom-de-la-autoconstruccion-en-el.html 
16. Charcoal Collectors, Manila, Philippines - Hannah Reyes

http://news.nationalgeographic.com/news/energy/2012/01/pictures/120125-charcoal-fuel-scavengers-manila/

17. Jakarta Public Housing - Alvin Hermanto

http://journals.worldnomads.com/alvinhermanto/photos/25076/Indonesia/My-Photo-scholarship-2010-entry

18. Dharavi Public Housing

http://www.airoots.org/2008/05/

19. Satellite Image, Kibera Nairobi

http://blog.buildllc.com/2008/02/dwelling-scapes/

20. Social Segregation in Paraisopolis, Brasil - Urban Age

http://urban-age.net/10_cities/08_saoPaulo/_essays/SA_Caldeira.html

21. Haiti Shanty-town destroyed by 2010 earthquake - Logan Abassi

http:/news.nationalgeographic.com/news/2010/01/photogalleries/100114-aerial-haiti-earthquake-pictures/\#/downtown-haitiearthquake-aerial_11897_600×450.jpg

22. Garbage City - Esther Lee

http://www.skyscrapercity.com/showthread.php?t=131517\&page $=25$

23. Chimalhuacan, Mexico, Open air garbage pit - A. Gutierrez

http://www.flickr.com/photos/23742283@N02/with/2263597459/

24. Rooftops of Kibera, Nairobi - S. Henry

http://sabrinahenry.com/2010/01/28/kibera-life-in-the-slums/

25. Squatter Settlement, Manila - Neal Oshima 2006

http://www.urbanlandscape.org.uk/nealo/squatter00.htm

26. Electric Stairs in Medellin, Colombia, $2012-G$. Restreppo

http://www.elmundo.com/portal/noticias/movilidad/medellin_tiene_las_primeras_escaleras_electricas_del_mundo_para_movilidad_urbana_.php

\section{SLUM-ARCHITECTURE / HYPER-AESTHETICS}

27. Squatter Settlement, Manila - Neal Oshima 2006

http://www.urbanlandscape.org.uk/nealo/squatter00.htm

28. Guggenheim, Bilbao - R. Llano

http://11870.com/pro/guggenheim-bilbao-museoa/media/f49d9052

29. Guanzhou Opera House - Christian Richters

http://www.dezeen.com/2011/02/25/guangzhou-opera-house-by-zaha-hadid-architects/

30. Dubai, United Arab Emirates - Unknown Source

http://progressivetimes.wordpress.com/2010/02/23/dubai-the-nemesis-of-sustainability/

31. Sonapur Labour Camp, Dubai - Matilde Gattoni

http://matildegattoni.photoshelter.com/image/10000GPqzzYUxZng

32. Plan Voisin, Le Corbusier

http://www.archdaily.com/15271/learning-from-the-slums-12literature-and-urban-renewal/

33. Squatter Settlement, Metro Manila - Neal Oshima 2006

http://www.urbanlandscape.org.uk/nealo/squatter00.htm 
34. Dharavi Slum, Mumbai - Scott Eells

http://www.boston.com/bostonglobe/ideas/articles/2009/03/01/learning_from_slums/?page=full

35. Kolkota, India - Shayamal Das

http://davidepetilli.com/blog/

\section{SQUATTER AGENCY}

36. New Building Slum in Equatorial Guinea - Paolo Woods

http://www.paolowoods.net/

37. Streets of Dharavi, India - Jonas Bendiksen

http://ngm.nationalgeographic.com/2007/05/dharavi-mumbai-s/um/jacobson-text

38. Mexico City urban growth over time - Alberto Kalach

http://www.kalach.com/proyectos/ciudad-futura/ciudadfutura.html

39. Slum Intervention Capsules - Lebbeus Woods 2008

http://lebbeuswoods.wordpress.com/2008/02/09/slums-one-idea/

40. Iquique Housing Project by Elemental - T. Jarocha

http://www.elementalchile.cl/category/vivienda/iquique/

41. Bosque de La Esperanza (Hope Forest), Bogota, Colombia - Giancarlo Mazzanti http://www.domusweb.it/en/architecture/el-bosque-de-la-esperanza/

42. Metrocable Medellin by Urban Think Tank - R. Sajo

http://en.wikipedia.org/wiki/File:Torres_Metro_Cable(2)-Medellin.JPG

43. Informal Housing Strategy by Estudio Teddy Cruz

http://design-your-life.org/index.php?id=72

44. Favela Painting in Santa Maria, Rio de Janeiro - Joroen Koolhaas and Dre Urhahn

$\mathrm{http} / / /$ thehappening.com/1522/favela-painting-rio-de-janeiro

\section{THE PARACHUTIST'S ALTERNATIVE}

45. Mexico City Urban Sprawl - Pablo Lopez Luz

http://foam.org/photographers///lopez-luz,-pablo

46. Ciudad Nezahualcoyotl, Mexico City - Ciudad Futura, A. Kalach

http://www.kalach.com/proyectos/ciudad-futura/ciudadfutura.html

47. Floods in Valle del Chalco, Mexico City - Ciudad Futura, A. Kalach

http://www.kalach.com/proyectos/ciudad-futura/ciudadfutura.html

48. Mexico City Sprawl - Unknown Source

49. Mexico City and the former Lakebed - Observatorio Panamericano

Chimalhuacan, Mexico: How to Regenerate a Urban Fabric Resulting from Accelerated and Irregular Settlement Processes. Publication. Observatorio Panamericano Paisaje Territorio Arquitectura, 2011.

50. Colonia Popular in Mexico City - Edgar Garrido

http://www.noticias24.com/internacionales/noticia/24260/advierten-que-mexico-esta-al-borde-de-la-hambruna-y-el-estallido-social/

51. Chimalhuacan informal Growth - Ciudad Futura, A. Kalach

http://www.kalach.com/proyectos/ciudad-futura/ciudadfutura.html

52. Chimalhuacan, from the lake bed looking towards the Chimalhuachi Hills - A. Gutierrez

http://www.flickr.com/photos/23742283@N02/with/2263597459/ 
53. Chimalhuacan, from the Chimalhuachi Hills looking towards the Lakebed- A. Gutierrez http://www.flicks.com/photos/23742283@N02/with/2263597459/

54. Chimalhuacan Aereal Views

hitp://concurso.oppta.org/files/7013/3133/5100/MX_CHIMALHUACAN.pdf

55. Open Air dump site next to urban population in Chimalhuacan

http://www.flickriver.com/places/Mexico/Mexico/Chimalhuac\%C3\%A1n/La+Loba/

56. Open Air drain and poorly maintained road in Chimalhuacan

Image provided by Observatorio Panamericano, http://www.observatoriopanamericano.org/es

57. Urban Growth Over time Plan - Chimalhuacan Municipal Government Based on information provided by:

http://www.edomex.gob.mx/sedur/planes-de-desarrollo/municipales/chimalhuacan

58. Chimalhuacan Land Use - Chimalhuacan Municipal Government

Based on information provided by:

http://www.edomex.gob.mx/sedur/planes-de-desarrollo/municipales/chimalhuacan

59. Chimalhuacan's Growth Over time - Platform for Urban Investigation Mexico

http://www.allardvanhoorn.com/biography_pui_mex.asp

60. Satellite Image - Google Maps

61. Site Pictures - Google Street View

http://maps.google.cal

NOTE: All other images, plans and maps were created by the author Dustin Unrau 


\section{WORKS CITED}

- Martine, George. The New Global Frontier: Urbanization, Povern and Enironment in the 21st Centurn: London: Earthscan, 2008. Print.

- "MoMA | Small Scale, Big Change | Manguinhos Complex." MoMA. Web. 25 Mar. 2012.<http://www.moma.org/ interactives/exhibitions $/ 2010 /$ smallscalebigchange/projects/manguinhos_complex $>$.

- World Development Report 2009: Reshaping Economic Geography. Washington, DC: World Bank, 2009. Print.

- Neuwirth, Robert. Shadon Cities: A Billion Squatters, a New Urban World. New York: Routledge, 2005. Print.

- Fogelson, Robert. Downtown: Its Rise and Fall: 1880-1950. Yale UP, 2001. Print.

- Tibaijuka, Anna. Report of the Fact-Finding Mission to Zimbabwe to Assess the Scope and Impact of Operation Murambatsvina. Rep. United Nations, July 2005. Web. <http://ww2.unhabitat.org/documents/ZimbabweReport. pdf $>$.

- "Priests Told: Don't Aid "filth'," Sunday Times (UK) 19 July 2005. Print.

- Timberg, Craig. "A Long, Hard Slog in Zimbabwe." The Washington Post 07 Feb. 2008. Print.

- Aquilino, Marie Jeannine. Beyond Shelter: Architecture and Human Dignity. New York, NY: Metropolis, 2010.

- Rinpoche, Sogyal. The Tibetan Book of Living and Dying: Sogyal Rinpoche. Berkeley, CA: Audio Literature, 1993. Print.

- Hobbs, May. Born to Struggle. Plainfield. VT: Daughters, 1975. Print.

- Sutherland, Ben. "BBC NEWS | In Depth | Slum Dwellers 'to Top 2 Billion"” BBC News - Home. Web. 06 Feb. 2012. <http://news.bbc.co.uk/2/hi/5099038.stm>.

- Alex Steffan, World Changing: A User's guide for the $2 I^{\prime \prime}$ Centurn, Abrams, New York, 2006.

- Tuhus-Dubrow, Rebecca. "Learning from Slums." Boston Globe 1 Mar. 2009. Print.

- United Nations Department of Economic and Social Affairs/Population Division, World Urhanization Prospects: The 2009 Revision

- UN-HABITAT, An urbanising World: Global Report on Human Settlements, Oxford 1996.

- Davis, Mike. Planet of Slums. London: Verso, 2006.

- UN-HABITAT, "Slums of the World: The Face of Urban Poverty in the New Millenium?," Nairobi 2003, annex 3.

- Keith Pezzoli, Human Settlements and Planning for Ecological Sustainability: The case of Mexico City, Cambridge 1998 .

- Gustavo Garza, "Global Economy, Metropolitan Dynamics and Urban Policies in Mexico", Cities 16:3. Mexico 1999.

- Gregory Guldin, What 's a peasant to do? . Westview Press, Boulder, 2001

- Thomas Sieverts. Cities nithout cities: an interpretation of the Zuischenstadt, London 2003

- Davis, Mike. "Haussmann in the Tropics." World-Information.Org. Web. 06 Feb. 2012.<http://world-information. org/wio/readme/992003309/1154965269>. 
- Evers and Korff, Southeast Asian Urbanism

- Nick Devas, "Can City Governments in the South Deliver for the Poor?" International Development and Plamning Review 25:1 (2003)

- Soliman, in Ananya Roy and Nezar Al Sayyad (eds), Urban informality: Transnational Perspectives from the Middle East, Latin America, and South Asia, Lanham (Md.) 2004

- De Soto, Hernando. The mystery of Capital: Why capitalism triumphs in the west and fails everywhere else, New York 2000

- Alan Gilbert and Ann Varley, Landlord and tentant: Housing the Poor in Urban Mexico, London 1991

- Rousseau, Jean-Jacques, and Immanuel Kant. Rousseau: On the Origin of Inequality. Vol. Part II. Chicago: Great Foundation.

- Verma, Gita, Slumming India: A Chronicle of Slums and Their Saviours, London 2003

- Intermediate Technology Development Group (ITDG) East Africa Newsletter (August 2002).

- UN Habitat. The Challenge of Slums: Global Report on Human Settlements, 2003. London: Earthscan, 2003.

- Koolhaas, Rem. "In Search of Authenticity." The Endless City: The Urban Age Project By Richard Burdett and Deyan Sudjic. London: Phaidon, 2007. Print.

- Cruz, Teddy. "Design Ops." Architecture at the Edge of Everything Else. Ed. Esther Choi and Marrikka Trotter. Cambridge, MA: Work, 2010.

- Bell, Bryan, and Katie Wakeford. Expanding Architecture: Design as Activism. New York: Metropolis, 2008. Print.

- Prat, Ramon. "Dubai: Global City Guaranteed?" Verb Crisis. Barcelona: Actar, 2008. Print.

- Lewis, Michael J., "The rise of the Starchitect". The New Criterion, London, 2007. Print.

- Coulombel, Patrick. "Afterword." Beyond Shelter: Architecture and Human Dignity. By Marie Jeannine Aquilino. New York, NY: Metropolis, 2010. Print.

- Till, Jeremy. Architecture Depends. Cambridge, MA: MIT, 2009. Print.

- $\quad$ Freud, Sigmund. Civilization and Its Discontents. New York: W.W. Norton, 1962. Print.

- “Zaha's way" Lebbeus Woods. Web. 06 Feb. 2012. <http://lebbeuswoods.wordpress. com/2011/03/27/zahas-way/>.

- "Slumchitecture." Where. Web. 18 Jan. 2012. <http://thewhereblog.blogspot.com/2009/04/slumchitecture.html>

- Booth, Robert. "Charles Declares Mumbai Shanty Town Model for the World $\mid$ Art and Design $\mid$ The Guardian." | The Guardian. Web. 18 Jan. 2012. <http:/www.guardian.co.uk/ artanddesign/2009/feb/06/prince-charles-slumcomments>.

- Burdett, Richard, and Deyan Sudjic. The Endless City: The Urban Age Project by the London School of Economics and Deutsche Bank's Alfred Herrhausen Society. London: Phaidon, 2007. Print.

- "SLUMS: What to Do?" Lebbeus Woods. Web. 16 Feb. 2012. <http://lebbeuswoods.wordpress.com/2008/01/28/ slums-what-to-do/>.

- Kalach, Alberto, and Lipkau. Gustavo, México: Ciudad Futura. Barcelona: RM Verlag, 2010. Print.

- Schneider, Tatjana, and Jeremy Till. "Beyond Discourse: Notes on Spatial Agency."FOOTPRINT 4 (2009)

- Giddens, Anthony. Social Theory and Modern Sociology. Stanford, CA: Stanford UP, 1987. Print. 
- "Censo De Poblacion Y Vivienda 2010.Resultados Preliminares." Censo De Poblacion Y Vivienda 2010. Resultados Preliminares. Web. 04 Mar. 2012. <http:/www.inegi.org.mx/sistemas/TabuladosBasicos/preliminares2010. aspx>.

- "Mexico City: Growth at the Limit?" Urban Age. Web. 04 Mar. 2012.<http://urban-age.net/03_conferences/ conf_mexicoCity.html>.

- Connolly, Priscilla. Urban Slums Report: The Case of Mexico City, Mexico. Rep. London: Development Planning Unit, University College London, 2003. Print.

- Connolly, Priscilla. "Understanding Slums: Case Studies for the Global Report 2003." UN Habitat. Web. 04 Mar. 2012. <http://www.ucl.ac.uk/dpu-projects/Global_Report/cities/mexico.htm>

- "Inegi.gob.mx - Instituto Nacional De Estadistica Y Geografia (INEGI)." INEGI. Web. 04 Mar. 2012.<http:// www.inegi.gob.mx>.

- Chimalhuacan, Mexico : How to Regenerate a Urban Fabric Resulting from Accelerated and Irregular Settlement Processes. Publication. Observatorio Panamericano Paisaje Territorio Arquitectura, 2011. Print.

- "Lago De Texcoco." Los Diccionarios Y Las Enciclopedias Sobre El Academico. Web. 12 Mar. 2012.<http:// www.esacademic.com/dic.nsf/eswiki/703505>.

- Huamán, E (2000) "Dos supuestos acerca de la regularización de la tenencia de la tierra: el caso de Chimalhuacán, México",in A. Iracheta and M. Smolka (coords.) Los Pobres de la Ciudad y La Tierra. El Colegio Mexiquense/Lincoln Institute ofLand Policy, Zinacantepec, México.

- Plan Municipal De Desarrollo Urbano Chimalhuacán 2009-2012. Chimalhuacan: Gobierno Municipal Nuevo Chimalhuacan, 2009. Print.

- "Sociedad Y Poder." Sociedad Y Poder. Web. 31 Mar. 2012. <http://sociedad.wordpress. com/2005/12/10/la-lobaretrato-de-un-sistema-corrompido-2/>.

- “Arqueologia De La Ilegalidad." Arqueologia De La Ilegalidad. Web. 31 Mar. 2012. <http://www. letraslibres. com/revista/convivio/arqueologia-de-la-ilegalidad $>$.

- "La Jornada." Defraudadas Por La Loba Y Hostigadas Por Ex Comuneros Sobreviven Cientos De Familias. Web. 31 Mar. 2012. <http:/www.jornada.unam. $m x / 2006 / 11 / 30 /$ index.php? section=estados>.

- Frykman, Carina. The Power of Waste: A Study of Socio-Political Relations in Mexico City's Waste Management System. Rep. Print. P.13

- "Milenio." Explosion En Basurero Abre Grieta Y Dana 400 Viviendas. Web. 31 Mar. 2012.<http://www.milenio. $\mathrm{com} / \mathrm{cdb} / \mathrm{doc} /$ noticias $2011 / 7 \mathrm{c} 954 \mathrm{~b} 2 \mathrm{a} 681 \mathrm{dd} 8 \mathrm{c} 89 \mathrm{db} 2 \mathrm{c} 26 \mathrm{caf} 4 \mathrm{fbd} 85>$.

- "Milenio." Aun Cerrado, Basurero Tlatel Xochitenco Sigue Generando Molestias. Web. 31 Mar. 2012. <http://edomex.milenio.com/cdb/doc/noticias2011/419fdc3369c49add 19f8a4d91 5c lc697>. 